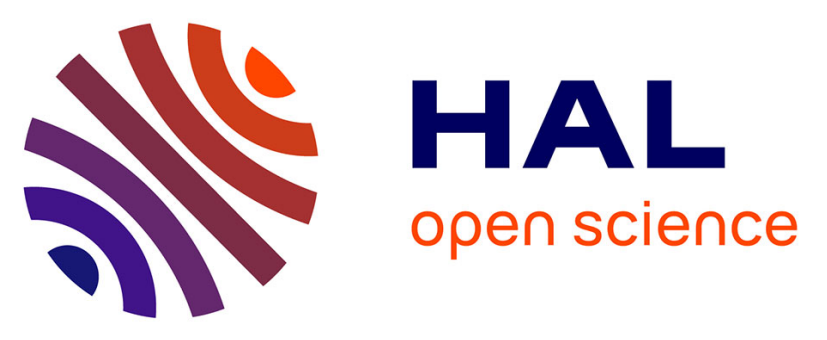

\title{
The Siderian-Orosirian magmatism in the Archean Gavião Paleoplate, Brazil: U-Pb geochronology, geochemistry and tectonic implications
}

Simone Cerqueira Cruz Pereira, Johildo Salomão Figuereido Barbosa, Marilda

Santos Pinto, Jean-Jacques Peucat, Jean-Louis Paquette, Jailma Santos de

Souza, Violeta de Souza Martins, Farid Chemale Junior, Mauricio Antonio

Carneiro

\section{- To cite this version:}

Simone Cerqueira Cruz Pereira, Johildo Salomão Figuereido Barbosa, Marilda Santos Pinto, JeanJacques Peucat, Jean-Louis Paquette, et al.. The Siderian-Orosirian magmatism in the Archean Gavião Paleoplate, Brazil: U-Pb geochronology, geochemistry and tectonic implications. Journal of South American Earth Sciences, 2016, 69, pp. 43-79. 10.1016/j.jsames.2016.02.007 . insu-01293620

\section{HAL Id: insu-01293620 \\ https://hal-insu.archives-ouvertes.fr/insu-01293620}

Submitted on 29 Mar 2016

HAL is a multi-disciplinary open access archive for the deposit and dissemination of scientific research documents, whether they are published or not. The documents may come from teaching and research institutions in France or abroad, or from public or private research centers.
L'archive ouverte pluridisciplinaire HAL, est destinée au dépôt et à la diffusion de documents scientifiques de niveau recherche, publiés ou non, émanant des établissements d'enseignement et de recherche français ou étrangers, des laboratoires publics ou privés. 


\section{Accepted Manuscript}

The Siderian-Orosirian magmatism in the Archean Gavião Paleoplate, Brazil: U-Pb geochronology, geochemistry and tectonic implications

Simone Cerqueira Pereira Cruz, Johildo Salomão Figueiredo Barbosa, Marilda Santos Pinto, Jean-Jacques Peucat, Jean Louis Paquette, Jailma Santos de Souza, Violeta de Souza Martins, Farid Chemale Júnior, Mauricio Antonio Carneiro

PII: S0895-9811(16)30018-9

DOI: 10.1016/j.jsames.2016.02.007

Reference: $\quad$ SAMES 1528

To appear in: Journal of South American Earth Sciences

Received Date: 31 August 2015

Revised Date: 16 February 2016

Accepted Date: 26 February 2016

Please cite this article as: Pereira Cruz, S.C., Figueiredo Barbosa, J.S., Pinto, M.S., Peucat, J.J., Paquette, J.L., Santos de Souza, J., de Souza Martins, V., Júnior, F.C., Carneiro, M.A., The Siderian-Orosirian magmatism in the Archean Gavião Paleoplate, Brazil: U-Pb geochronology, geochemistry and tectonic implications, Journal of South American Earth Sciences (2016), doi: 10.1016/ j.jsames.2016.02.007.

This is a PDF file of an unedited manuscript that has been accepted for publication. As a service to our customers we are providing this early version of the manuscript. The manuscript will undergo copyediting, typesetting, and review of the resulting proof before it is published in its final form. Please note that during the production process errors may be discovered which could affect the content, and all legal disclaimers that apply to the journal pertain. 
a) $2400-2330$ (?) Ma

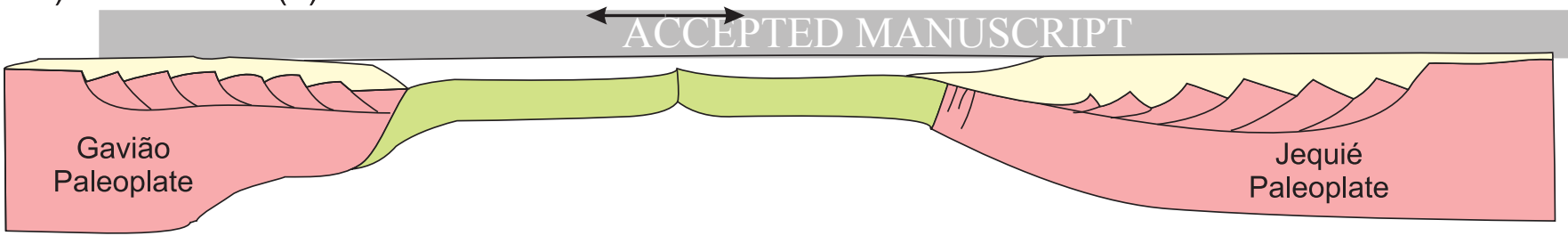

b) $2380-2120 \mathrm{Ma}$

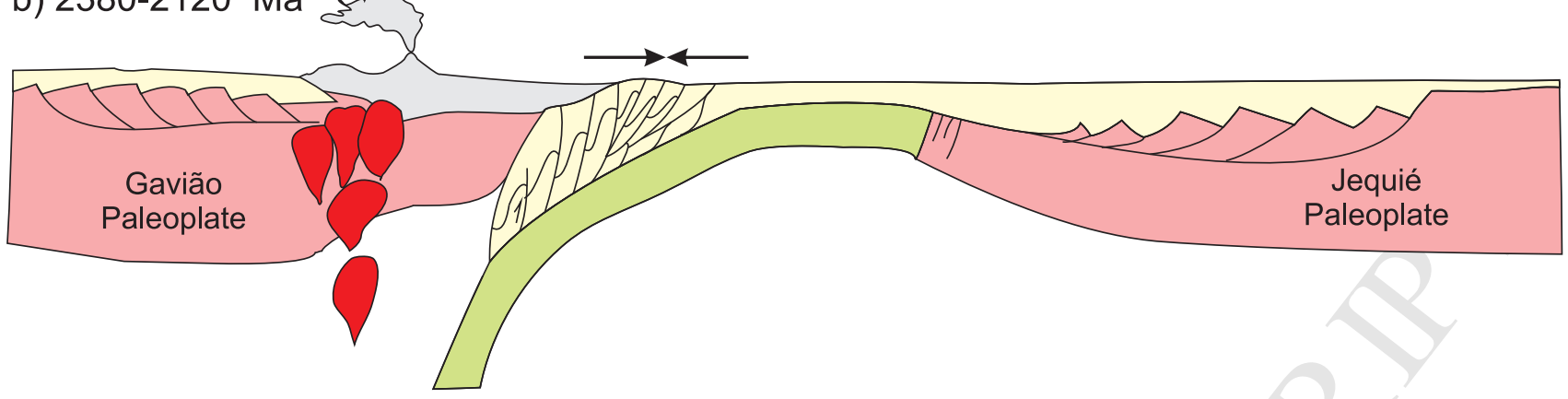

c) $2100-2090 \mathrm{Ma}$

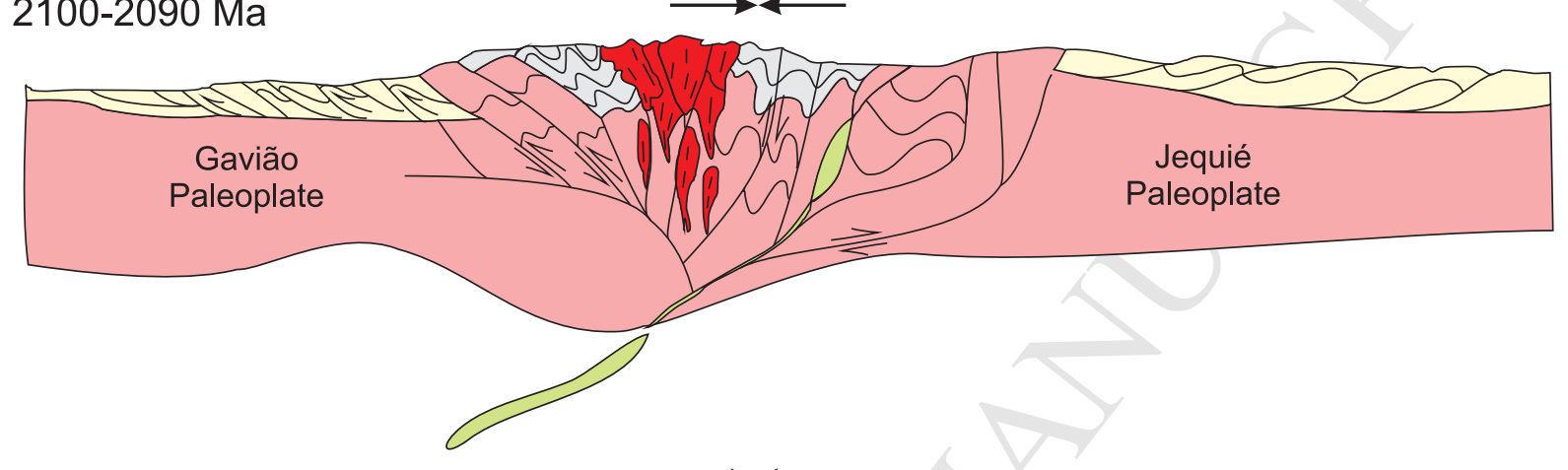

d) 2066-2030 Ma
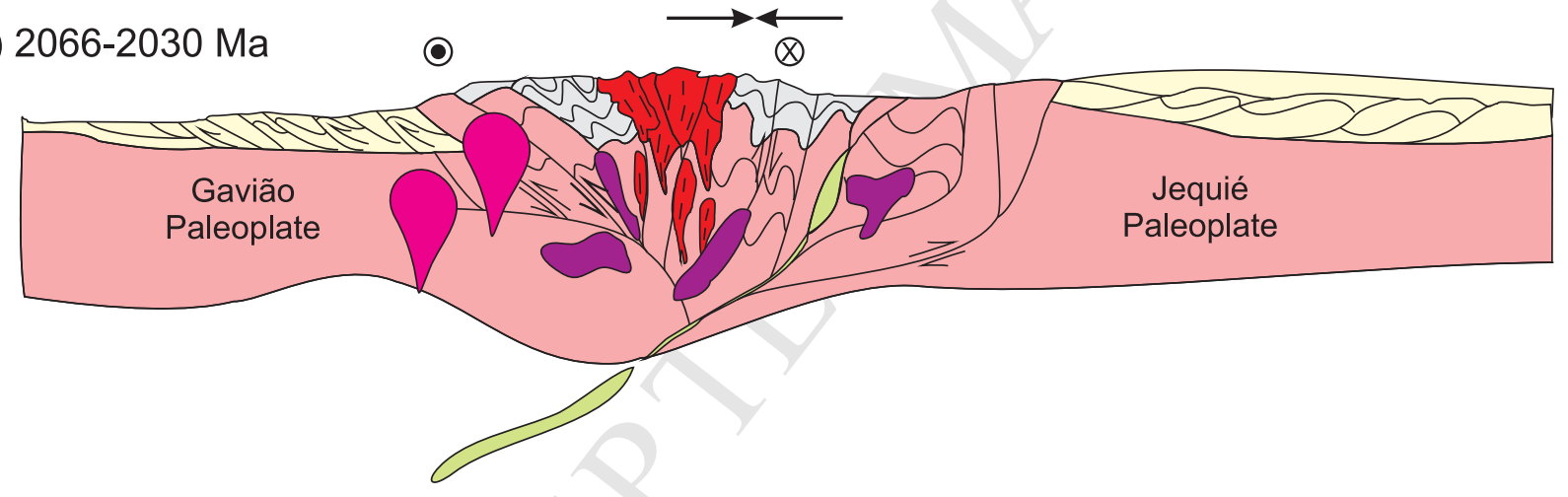

d) 2030-1900 Ma

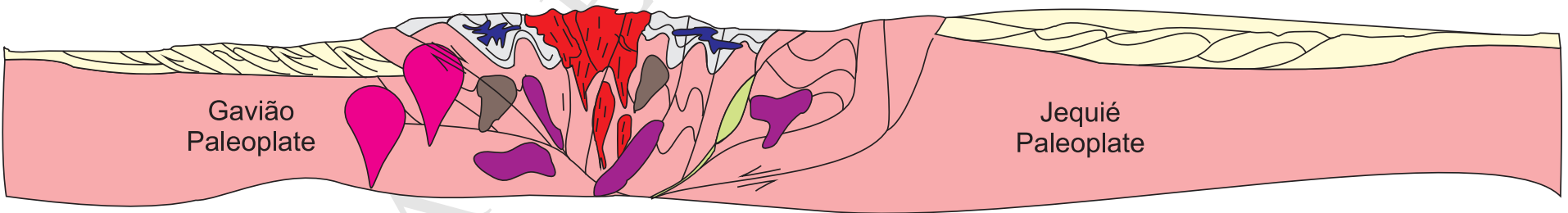

Legend

Calk-alkali, alkali-calcic to alkali granitoids (Grupo 2d)

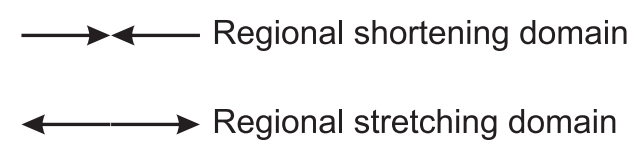

Alkali-calcic to alkali granitoids(Grupo 2c)

Alkali-calcic to alkali granitoids (Grupo $2 b$ )

Alkali to alkali - calcic granitoids (Group 2a)

Calcic to calk-alkalic, pre-collisional granitoids (Group 1)

$\otimes \odot$ sinistral movement

$\Sigma$ reverse movement

normal movement

Metavolcanosedimentary rocks associated with Siderian-Riacian magmatic arc

Syn to pre-collisional metasedimentary rocks

Oceanic crust

Archean orthogneisses 


\section{The Siderian-Orosirian magmatism in the Archean Gavião Paleoplate, Brazil: U-Pb}

\section{geochronology, geochemistry and tectonic implications}

Simone Cerqueira Pereira Cruz ${ }^{\mathrm{a}}$, Johildo Salomão Figueiredo Barbosa ${ }^{\mathrm{a}}$, Marilda Santos Pinto $^{\mathrm{b}}$, Jean-Jacques Peucat ${ }^{\mathrm{c}}$, Jean Louis Paquette ${ }^{\mathrm{d}}$, Jailma Santos de Souza ${ }^{\mathrm{a}}$, Violeta de Souza Martins $^{\mathrm{e}}$, Farid Chemale Júnior ${ }^{\mathrm{f}}$, Mauricio Antonio Carneiro ${ }^{\mathrm{g}}$

${ }^{\text {a }}$ Universidade Federal da Bahia (UFBA), Departamento de Geologia, Programa de Pesquisa e Pós-Graduação em Geologia, Centro de Pesquisa em Geofísica e Geologia. Rua Barão de Geremoabo, s/n, Federação, 40170-209, Salvador-BA, Brazil.simonecruzufba@gmail.com (S. C. P. Cruz, Corresponding Author, 557187447636), johildo@cpgg.ufba.br, jailmasouza@gmail.com

${ }^{\text {b }}$ Universidade Estadual de Feira de Santana (UEFS), Departamento de Ciências Exatas, Av. Transnordestina, s/n, Novo Horizonte, 44036-900, Feira de Santana-BA, Brazil, mspinto@atarde.com.br

c Géosciences Rennes, UMR CNRS 6118, Université de Rennes I, 35042, Rennes Cedex, France,peucat@univ-rennes1.fr

d Laboratoire Magmas et Volcans, Département de Géologie, OPGC e Université Blaise Pascal, CNRS e IRD, 5 rue Kessler, 63038 Clermont e Ferrand, France, paquette@opgc.univbpclermont.fr

${ }^{\text {e }}$ CPRM - Serviço Geológico do Brasil, Superintendência Regional de Salvador, Av. Ulysses Guimarães, 2862, Sussuarana/CAB, $41213 \quad 000, \quad$ Salvador-BA, $\quad$ Brazil. violeta.martins@cprm.gov.br

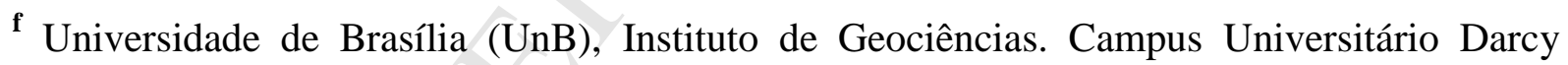
Ribeiro 70910-900, Brasília-DF, Brazil, fchemale@unb.br

g Universidade Federal de Ouro Preto (UFOP), Departamento de Geologia, Morro do Cruzeiro, 30400-000, Ouro Preto-MG, Brazil.mauricio@ degeo.ufop.br

\section{Abstract}

The southern portion of the Gavião Paleoplate is composed by Archean orthogneisses, Archean-Paleoproterozoic metavolcano-sedimentary rocks and Siderian-Rhyacian-Orosirian granitoids. Petrographic, geochemical, U-Pb (Laser Ablation, ICPMS) and Sm-Nd data are 
presented for five Paleoproterozoic granitoids that were recently mapped: Jussiape II, Lagoa das Almas, Humaitá, Belo Campo and Broco granitoids. These granitoids present $\mathrm{U}-\mathrm{Pb}$ zircon respectively. In addition to these granitoids, another twenty-five ones were identified and studied by several authors, resulting in a total of twenty-nine plutons. Despite the previous petrography, geochemistry and geochronology studies that have been performed, no model had been proposed to explain the tectonic setting of this extensive granitogenesis. Integration Integration of the new data and the literature has been done and corresponds to the second part of the article. Based on U-Pb dating and geochemical data, Siderian-Rhyacian-Orosirian granitoids of the southern Gavião Paleoplate were classified into five groups, or five suites: 1 $(2,324 \pm 6$ to $2,091 \pm 6.6 \mathrm{Ma}), 2 \mathrm{a}(2,054-6 /+8$ to $2,041 \pm 23 \mathrm{Ma}), 2 \mathrm{~b}(2,066 \pm 37$ to $2,019 \pm 32$ $\mathrm{Ma}), 2 \mathrm{c}(2,058 \pm 8$ to $1,852 \pm 50 \mathrm{Ma})$ and $2 \mathrm{~d}(2,049 \pm 12$ to $1,929 \pm 16 \mathrm{Ma})$. The granitoids of Group 1 present heterogeneous deformation, while the granitoids of groups $2 \mathrm{a}$ to $2 \mathrm{~d}$ are generally not deformed. Usually the rocks are potassic, but sodic granitic rocks can be found in samples of groups 1, 2c and 2d. Several chemical classification parameters are presented and discussed herein, but it is noteworthy that the granitoids of Group 1 are mainly classified as calcic to calc-alkalic, while the rocks of the second group are mostly classified as alkalic ones. In the remaining groups, the samples vary between calc-alkalic and alkali-calcic. The $\varepsilon_{\mathrm{Nd}}$ values range between 4.0 and -15.4 and suggest an important and varied share of the continental crust in the formation of these rocks. The Humaitá granitoid probably presents the lowest contribution from the continental crust in its genesis. The rocks from Group 1 were generated as the product of an active continental margin arc situated eastwards from the southern portion of the Gavião Paleoplate. The spatial distribution between the granitoids of groups 1 and 2a suggests westwards subduction and led to a cordilleran model for the Western Bahia Magmatic Arc. Continental collision between the Gavião and Jequié paleoplates occurred around $2.09 \mathrm{Ga}$ and was followed by the setting of late-collision granitoids of groups $2 \mathrm{a}$ to $2 \mathrm{~d}$. The comparison between the tectonic model presented in this study and other existing models that explain the Siderian-Rhyacian-Orosirian granitogenesis of the Mineiro Belt and Mantiqueira Complex suggests a continuation of the Western Bahia Magmatic Arc and of the collisional orogen that followed, towards the south. The Western Bahia Magmatic Arc emplacement occurred before the Paleoproterozoic granitogenesis of the Serrinha (BahiaBrazil) and Congo (Africa) paleoplates. 
Keywords: granitoids, Siderian-Orosirian, Gavião Paleoplate, São Francisco Craton.

${ }_{1}^{66}$

267

\section{Introduction}

The northern portion of the São Francisco Craton of instead of by composed of four tectonic units, denominated herein for the first time as the Gavião, Jequié, Serrinha, and Uauá paleoplates (Fig. 1). These paleoplates are composed of Archean nuclei (Bastos Leal et al. 1998, Santos Pinto et al. 1998, 2012, Cruz et al. 2012) and Siderian-Orosirian accretions (see synthesis in Silva et al. 2002a, Barbosa et al., 2012 and discussion of the present study). They were involved in Paleoproterozoic collisions that resulted in the Itabuna-Salvador-Curaçá orogen (Barbosa and Sabaté 2002, 2004) in the eastern part of the São Francisco Craton, with a metamorphic peak reaching the granulite facies ca. 2150-2050 Ma (Silva et al. 1997,_2002a, Barbosa and Sabaté, 2002, 2004; Peucat et al., 2011). As a consequence of its previous residence in Gondwana, the São Francisco Craton has an African counterpart (Fig. 1), which is represented by the Congo Craton (Alkmim and Martins Neto 2012). The counterpart of this orogen in the Congo Craton is the West Central African Belt (Trompette, 1994; Feybesse et al., 1998). Both crustal segments were connected until the Early Cretaceous, when West Gondwana started to split apart within the context of Pangaea breakup (Porada, 1989; Trompette, 1994; Ledru et al., 1994; Feybesse et al., 1998; Pedrosa Soares et al., 1992, 2001, Silva et al., 2008).

\section{Figure 1}

The Gavião Paleoplate was previously defined by Barbosa and Sabaté $(2002,2004)$ and Souza et al. (2003) as the Gavião Block. It consists of Archean tonalitic, granodioritic and granitic gneisses and migmatites exposed together with Archean metavolcanosedimentary sequences (Figs. 1 and 2). In the southern Gavião Paleoplate, these units are intruded by Siderian/Rhyacian (2.38 to $2.05 \mathrm{Ga})$ and Orosirian $(2.05$ to $1.80 \mathrm{Ga})$ granitoids as batholiths, dikes and stocks. This extensive granitogenesis in the southern region of the Gavião Paleoplate has been described in studies carried out by several authors, among which are Santos Pinto et al. (1998, 2012), Rosa (1999), Arcanjo et al. (2005), Leal et al. (2005), Guimarães et al. (2005), Loureiro et al. (2010) and Barbosa et al. (2012). However, despite the detailed petrography, geochemistry and geochronology studies that exist, none has integrated these data with the intention of elaborating an evolution model to explain the 
tectonic setting of these granitoids. Geological mapping performed at a scale of 1:100,000 by Cruz et al. (2009, 2014a) revealed the existence of four new granitoids, denominated Lagoa das Almas, Humaitá, Belo Campo and Broco. Moreover, the Jussiape Granite was mapped in detail, at a scale of 1:25,000 (Cruz 2004), and divided into two groups: Jussiape I, that represents the body studied by Guimarães et al. (2005), with U-Pb age (zircon, LA-ICPMS) of $2,121 \pm 2.2$ (Table 1), and Jussiape II, investigated in the present study.

The present study first presents new petrographic, geochemical, U-Pb (LA-ICPMS) zircon ages and $\mathrm{Nd}$ isotope data results obtained for Jussiape II granitoid, as well as for the Lagoa das Almas, Humaitá, Belo Campo and Broco granitoids, which were recently mapped. These new data seek to contribute towards the already existing archive of the granitoids from the southern region of the Gavião Paleoplate. The new data are then integrated to those already available in the literature, aiming to individualize magmatic suites to interpret interpret the tectonic context of the setting of the granitoids of these suites in face of the plate tectonic model. In addition, we present a comparison of the crystallization ages of the Paleoproterozoic magmatism in the São Francisco Craton (southern Gavião and Serrinha paleoplates, Brazil), in the Mantiqueira Complex, and in the Mineiro Belt (Brazil), which is part of the Minas Accretionary Orogen (Teixeira et al., 2015), with the West Central African Belt (Africa). This comparison was performed as a first attempt to demonstrate the diachronism between the evolution of the accretionary phase and the collisional phase of these orogenic systems in the scenario of the Columbia Supercontinent.

\section{Geological setting of the Gavião Paleoplate}

Previous geochronological datasets obtained for the southern portion of the Gavião Paleoplate suggest that the formation of the Archean continental crust was related to at least three main plutonic events at 3.4-3.3 Ga, 3.2-3.1 Ga and 2.9-2.6 Ga (Cordani et al., 1985, 1992; Martin et al., 1991, Marinho, 1991, Nutman and Cordani, 1993, Cunha et al., 1996, Santos Pinto, 1996, Santos Pinto et al., 1998, 2012; Bastos Leal, 1998, Peucat et al., 2002, Barbosa et al., 2012, Cruz et al., 2012). This paleoplate is composed of felsic gneisses, migmatites, amphibolites and granulites of Archean age, as well as remnants of metavolcanosedimentary sequences and greenstone belts (Cunha and Fróes, 1994, Cunha et al., 1994, Santos Pinto, 1996, Santos Pinto et al., 1998, 2012; Bastos Leal et al., 1998, Barbosa et al., 2012). The few available geochronological data of the metavolcanosedimentary sequence reveal a Meso- to Neoarchean age for the basal part of the 
stratigraphic pile (Marinho, 1991; Marinho et al., 2008, Bastos Leal et al., 2003, Cruz et al., 2014a, Zincone and Oliveira, 2014) and Siderian to Rhyacian age for the top sequence is composed of metagraywackes, meta-arkoses, metasandstones, quartzites, aluminous schists (metapelites), calcite/manganese-rich marbles and itabirites that are intercalated with mafic metavolcanic rocks. In the Caculé region (Fig. 2), Vitória (2014) identified meta-andesitic rocks intercalated with the metasedimentary rocks from the top of this sequence and a sample of metavolcanic rocks was dated at 2,218 \pm 18 Ma by Rodrigues et al. (2012).

Paleoproterozoic granitoids in the southern portion of the Gavião Paleoplate are represented by twenty-nine intrusive massifs (Fig. 2) which intrude Archean-Paleoproterozoic metavolcanosedimentary sequences and Archean gneissic-migmatitic terranes. These granitoids have varied forms, sizes and chemical characteristics (Bastos Leal, 1998, Bastos Leal et. al., 1998, Santos Pinto et al., 1998, Barbosa et al., 2012). The available zircon crystallization ages of these rocks range between 1,852 $\pm 50 \mathrm{Ma}$ and 2,380 Ma and are reported in table 1 . The main objective of the present study was to understand the tectonic meaning of this extensive granitogenesis. The $\varepsilon_{\mathrm{Nd}}(\mathrm{t})$ values vary between -4 and -15.4 (Tab. 1), which indicates an important crustal component in the genesis of these rocks.

Barbosa and Cruz (2011) reported the existence of migmatites with ages of $2.03 \mathrm{Ga}$ in this portion of the Gavião Paleoplate. On the other hand, Medeiros (2013) obtained U-Pb (SHRIMP) ages of 2,095 \pm 9 Ma for the migmatization of the Archean crust in the western region of the Gavião Paleoplate, close to the village of Riacho de Santana (Fig. 2). In turn, Barbosa et al. (2013) dated older metamorphism in Archean rocks located in the same village, Riacho de Santana (Fig. 2), at 2,250 2 Ma.

The Gavião Paleoplate is covered by Statherian and Tonian metavolcanosedimentary rocks (Fig. 2) associated with the Paramirim Aulacogen (Pedrosa Soares et al., 2001).

\section{Analytical Procedures}

In the present study, five granitoid bodies were investigated in terms of petrography, geochemistry and geochronology: Jussiape II, Lagoa das Almas, Humaitá, Belo Campo and Broco. The locations of the samples used for $\mathrm{U}-\mathrm{Pb}$ zircon and $\mathrm{Sm}-\mathrm{Nd}$ (whole rock) analyses are shown in figure 2, and the data are listed in tables 2 and 3.

Samples for isotope studies were crushed and milled using a jaw crusher and a ring mill apparatus to prepare bulk-rock powders. Zircon grains were separated from another 
aliquot of bulk-rock powders using conventional heavy liquid and magnetic procedures at the Universidade Federal de Ouro Preto. U-Pb zircon ages were obtained by LA-ICPMS at the geochronological laboratories of the Universidade de Brasília (samples SCP-SJ01 and SCP1351), Universidade do Rio Grande do Sul (Sample L-05) and the Université Blaise-Pascal (samples OPU 6356 and TB-05). Age calculation was carried out using the Isoplot-Ex spreadsheet (Ludwig, 2003). The Sm-Nd isotopic analyses of samples SCP-SJ-01 (Jussiape II granite) and SCP-1351 (Belo Campo granodiorite) were performed at the Geochronology Laboratory of the Universidade de Brasília (Brazil). A detailed description of the analytical procedures for the $\mathrm{Sm}-\mathrm{Nd}$ isotopes and $\mathrm{U}-\mathrm{Pb}$ zircon dating performed at the Universidade de Brasília can be found elsewhere (Gioia and Pimentel, 2000, Buhn et al., 2009, Chemale Jr. et al., 2011). For samples OPU 6356/F-05 (Humaitá Granodiorite) and TB-05Nd (Broco granodiorite), the isotope compositions for whole rocks were determined using a Finnigan Mat 262 mass spectrometer at Géosciences Rennes (France). Total blanks for Sm and Nd contents were lower than $0.05 \mathrm{ng}$. Uncertainties were $0.2 \%$ for ${ }^{147} \mathrm{Sm} /{ }^{144} \mathrm{Nd}$ ratios. $\mathrm{Nd}$ ratios were normalized to ${ }^{146} \mathrm{Nd} /{ }^{144} \mathrm{Nd}=0.7219$. All analyses were adjusted for variations of instrumental bias due to periodic adjustment of collector positions as monitored by measurements of the La Jolla, AMES or JNd standards. Neodymium crustal residence ages $\left(\mathrm{T}_{\mathrm{DM}}\right)$ were calculated following the depleted mantle model of DePaolo (1981). $\varepsilon_{\mathrm{Nd}(\mathrm{t})}$ values were calculated using as reference $\mathrm{U}-\mathrm{Pb}$ zircon ages where available or estimated ages based on regional geology and coherent results from nearby samples.

Whole rock analyses of major and trace elements were carried out at SGS GEOSOL Laboratórios Ltda and are reported in tables 4 to 7 . With the exception of $\mathrm{FeO}$, the major elements analysis was performed through X-ray fluorescence using samples fused with $\mathrm{Li}_{2} \mathrm{~B}_{4} \mathrm{O}_{7} . \mathrm{K}_{2} \mathrm{O}$ and $\mathrm{Na}_{2} \mathrm{O}$ were also analyzed by means of atomic absorption, after total dissolution with $\mathrm{HF}+\mathrm{HClO}_{4} . \mathrm{FeO}$ was determined through titration with potassium dichromate. Rb, Sr, Ba, Ga, Cs, Nb, Y, Zr, Hf, Ta, Th, U were determined by means of X-ray fluorescence, using the pressed powder technique. $\mathrm{F}$ was determined using the specific ion method. La, Ce, Nd, Sm, Eu, Gd, Tb, Dy, Ho, Er, Yb, Lu were analyzed through ICP-AES. The amount of $\mathrm{Fe}_{2} \mathrm{O}_{3}$ of each sample was determined based on the formula $\mathrm{Fe}_{2} \mathrm{O}_{3}=\mathrm{FeO}_{\mathrm{t}}$ (Total iron) - $1,11 \mathrm{FeO}$.

\section{Results}


and the performance of petrography, geochronology and geochemical studies broadens the volume of data that exists for the Paleoproterozoic granitoids of the region.

\subsection{Petrography results}

Jussiape II granite

The Jussiape II granite, exposed ca. $50 \mathrm{~km}$ to the northeast of the Brumado (Fig. 2, number 14), occupies the core of the Abaíra-Jussiape anticlinal (Cruz 2004). This pluton crops out with ca. $25 \mathrm{~km}$ in length and maximum width of $12 \mathrm{~km}$. Moreover, it is intrusive in the Rhyacian Jussiape I $(2,121 \pm 2.2$, Guimarães et al., 2005) and in the Archean Caraguataí syenitic suite $(2,696 \pm 5 \mathrm{Ma}$, Cruz et al., 2012). The rock types are hololeucocratic to leucocratic (Fig. 3a).

\section{Figure 3}

The rocks generally present syenogranitic composition (Fig. 4) and plot in the field of the aluminous granitoids found in the alkaline provinces of Lameyre and Bowden (1982). Xenoliths of amphibolites, meta-ultramafic rocks and metatexite migmatites are common. The two main facies are medium-grained phaneritic and medium-grained porphyritic, with recognizable isotropic and anisotropic bodies in both cases. The anisotropic and porphyritic bodies present magmatic flow foliation with oriented K-feldspar phenocrysts measuring 2 to 3 $\mathrm{cm}$ in size. This foliation presents an orientation of $262^{\circ} / 76^{\circ}$ (dip direction). The matrix of the porphyritic facies is medium-grained phaneritic and isotropic and is mainly constituted of quartz, K-feldspar and plagioclase. In both facies, the accessory phases include zircon, titanite, apatite, allanite and pyrite. Although rare, magnetite and biotite are also present. Myrmekitic and poikilitic igneous microstructures were observed, the latter revealed by the presence of apatite and zircon inclusions in plagioclase and biotite; allanite, zircon, titanite, apatite, magnetite and pyrite inclusions in biotite; plagioclase inclusions in K-feldspar; and biotite inclusions in plagioclase. The crystallization sequence is most likely zircon, titanite, apatite, magnetite and pyrite, followed by biotite, K-feldspar, plagioclase and quartz crystallized at later phases.

Figure 4 
This granitoid is located $5 \mathrm{~km}$ southwards from the village of Jacaraci (Fig. 2, number 4). The massif is approximately ellipsoidal, with $15 \mathrm{~km}$ in width and $23 \mathrm{~km}$ in length. It intrudes an association of aluminous schists, quartzites and gondites. The rocks (Fig. 3b) are generally anisotropic, predominantly medium-grained phaneritic, hololeucocratic to leucocratic with predominant granodioritic composition (Fig. 4). In the Lameyre and Bowden (1982) diagram, this granitoid plots in the field of calc-alkaline-trondhjemitic rocks (low K), though two samples plot in the field of calc-alkaline-granodioritic rocks (medium K) and one other in the field of tholeiitic rocks. Accessory minerals are zircon, titanite, apatite, biotite and magnetite. Locally, a porphyritic facies is also observed with medium- to fine-grained phaneritic matrix and anisotropic fabric, predominantly constituted of quartz, K-feldspar and plagioclase. In this facies, the K-feldspar phenocrysts are with approximately $1-2 \mathrm{~cm}$ to $3 \mathrm{~cm}$ in size.

The presence of perthites suggests it could be a subsolvus granitoid. The order of crystallization is similar to that suggested for the Jussiape II granite. The rock has a solid state magmatic foliation marked by the stretching of quartz and feldspars as well as the preferred orientation of biotite. Magmatic flow can be observed in low deformation domains and in the meso- and micro-scale by the preferential orientation of K-feldspar.

\section{Humaitá granodiorite}

This rock (Fig. 3c) occurs $15 \mathrm{~km}$ southwards from the village of Caetité (Fig. 2, number 5) with an approximately ellipsoidal shape, measuring $12 \mathrm{~km}$ in length by $6 \mathrm{~km}$ in width. This pluton also intrudes an association of quartzites, aluminous schists, itabirites and manganese-rich marbles. The rocks are gray, usually anisotropic, phaneritic, and mediumgrained. The predominant composition is granodioritic (Fig. 4), but samples with modal tonalitic and monzogranitic compositions were also found. The samples analyzed plot in the field of the calc-alkaline-granodioritic (medium K) series, though four samples are in the trend of calc-alkaline-trondhjemitic rocks (low K), according to Lameyre and Bowden (1982). This granodiorite contains biotite, zircon, allanite and titanite as accessory minerals. Biotite can be found included in K-feldspar, which is in turn included in plagioclase, marking the poikilitic texture. Perthites were observed in the K-feldspars. Deformation in the solid state for this granitoid is heterogeneous, with a finely spaced foliation. 


\section{Belo Campo granodiorite}

This granitoid (Fig. 3d) is leucocratic, mainly composed of monzogranite (Fig. 4), and with accessory minerals such as biotite, zircon, apatite and titanite. This rock is found mylonitized in the vicinities of the village of Belo Campo (Fig. 2, number 29). In the domains with less ductile deformation intensity, relicts of igneous textures are found, such as: (i) porphyritic, with larger K-feldspar grains inserted in a finer matrix; and (ii) poikilitic, with biotite, zircon, titanite and apatite inclusions in K-feldspar and plagioclase

\section{Broco granodiorite}

This body, located $20 \mathrm{~km}$ northwards from the village of Caculé (Fig. 2, number 27), is the product of the partial melting of the surrounding biotite- and garnet-bearing metapelites (Palmeiras 2010). Cordierite is rarely found. The host rock is a stromatic metatexite migmatites (Sensu Sawyer, 2008) and the Broco granodiorite occurs as fine layers in these metatexite migmatitos (Fig. 3e). The main body of the Broco granodiorite is a diatexite, in which nebulite and schlieren structures are found (Sensu Sawyer 2008). Biotite and garnet concentration domains forming restites were preserved in the melting. This rock is leucocratic to mesocratic, phaneritic and porphyritic, with plagioclase phenocrysts varying from mediumto coarse-grained. Mainly composed of granodiorite (Fig. 4), this rock is generally isotropic, but intense deformation domains are associated with Neoproterozoic shear zones.

\subsection{U-Pb geochronology}

Jussiape granite II

Sample SCP SJ01 was collected in a quarry (Fig. 2) located $2 \mathrm{~km}$ northeastwards from the village of Jussiape. The zircon grains display different types of morphology. (1) The main set corresponds to euhedral, generally dark and partially metamict grains, which exhibit high temperature types according to Pupin (1980). They can be considered as magmatic zircon grown in the granite (i.e., grains Z19 and 20, Fig. 5a, Tab. 2). Nineteen analyses, mostly performed in the center of the grains, resulted in a discordia line with an upper intercept at 2,052 $\pm 43 \mathrm{Ma}$ (MSWD $=1.2$, which was interpreted as the crystallization age of this facies of the Jussiape granite. The average ${ }^{207} \mathrm{~Pb} /{ }^{206} \mathrm{~Pb}$ age is similar to the upper intercept (Fig. 5a). (2) The second dataset corresponds to inner cores of five euhedral (Z4) or rounded grains (Z18), which yielded a poorly-defined mean ${ }^{207} \mathrm{~Pb} /{ }^{206} \mathrm{~Pb}$ age of $2,724 \pm 47 \mathrm{Ma}$ (MSWD $=3.8$; Fig. 5b). This set corresponds to inherited Archean zircon grains, which are of the same age of the adjacent syenitic 
Caraguataí pluton (Cruz et al., 2012). (3) A single core within grain Z14 was concordant at 3,115 $\pm 25 \mathrm{Ma}$ (Fig. 5b) and interpreted as the witness of an older Archean basement recognized in the southern Gavião Block (Santos Pinto et al., 1998, 2012).

\section{Lagoa das Almas granite}

The L-05 sample was collected in a quarry located $7 \mathrm{~km}$ southwestwards from Jacaraci (Fig. 2). The zircon grains are euhedral to subhedral and exhibit a fine oscillatory magmatic zoning (Fig. 5c, Tab. 2). Rounded inner cores were documented in some grains (Z8 in Fig. 5c). A set of 6 subconcordant to concordant analyses of the magmatic grain-type defined an upper intercept at 2,114 $\pm 24 \mathrm{Ma}$ with the lower intercept close to the origin (MSWD =0.48). The 2.1 Ga intercept corresponds to the crystallization age of the magmatic zircon crystals, whereas the lower one was interpreted as the result of an episodic lead loss during the Brasiliano orogeny. One zircon core yielded a concordant age at 2,250 $\pm 23 \mathrm{Ma}$, suggesting the occurrence of an older Paleoproterozoic component in the granite.

\section{Humaitá granodiorite}

Zircons grains from the Humaitá granodiorite are euhedral to subhedral, with cores surrounded by zoned overgrowths (Figs. 6a and b). A set of 11 overgrowths (out of 12, Tab. 2) defined an upper intercept age of 2,140 \pm 9 Ma $(M S W D=1.2)$, which was interpreted as the crystallization age of the granitoid (Fig. 6a). The cores provided a set of discordant and concordant points, with the latter ranging from $2.35 \mathrm{Ga}$ (spot 1.1) to $2.8 \mathrm{Ga}$ (spot 5.1). An older discordant grain was dated at ca 3.13 Ga (Fig. 6b, Tab. 2). These grains were interpreted as inherited from the basement intruded by the granite.

\section{Belo Campo granodiorite}

Sample SCP-1351 was collected at the Tremedal-Belo Campo Highway (BA 265), 15 km eastwards from the village of Tremedal (Fig. 2). The zircons crystals are elongated and euhedral to subhedral. They often contain cores (Fig. 6c) that can be well developed and only surrounded by very fine overgrowths (Z13 and Z8, Fig. 6d).

Two groups of ages were obtained. Eleven analyses corresponding to some whole grains and the overgrowths, defined a chord with an upper intercept at 2,049 $\pm 23 \mathrm{Ma}$ (MSWD = 3.3, Fig. 6c). Despite the poor quality of this alignment, this age could be interpreted as the emplacement of the granite. The second set is composed of older ages related to the occurrence of 
zircon cores, with ${ }^{207} \mathrm{~Pb} /{ }^{206} \mathrm{~Pb}$ ages ranging from $2.69 \mathrm{Ga}(\mathrm{Z} 13)$ to $3.13 \mathrm{Ga}(\mathrm{Z} 6)$. Four of these points (Fig. 6d) defined a mean ${ }^{207} \mathrm{~Pb} /{ }^{206} \mathrm{~Pb}$ age of $2,829 \pm 10 \mathrm{Ma}$ (MSWD $=1.0$ ), whose significance has not yet been understood. All zircon cores were interpreted as inherited and indicate crustal contamination.

\section{Broco granodiorite}

Sample TB05 was collected $15 \mathrm{~km}$ northwards of Caculé (Fig. 2). These zircon crystals are euhedral without any visible core. Most of the analyses are concordant and provide a ${ }^{207} \mathrm{~Pb} /{ }^{206} \mathrm{~Pb}$ mean age of $2,038 \pm 8 \mathrm{Ma}$, which was interpreted as the crystallization age of the rock (Fig. 6e, Tab. 2). The lack of inherited zircon grains in such a peraluminous granite is most likely explained by a high rate of differentiation. This sample also contained large monazite crystals, as frequently found in anatectic granites. The whole dataset of the monazite crystals provided a mean ${ }^{207} \mathrm{~Pb} /{ }^{206} \mathrm{~Pb}$ age of $1,964 \pm 9 \mathrm{Ma}$. This age is significantly younger than the zircon age, even if it is in the same range of ca $2.0 \mathrm{Ga}$. Thus, it may have recorded cooling following partial melting processes, or it could be related to late fluid flows.

\subsection{Sm-Nd isotopic results}

The Nd model age (Tab. 3) obtained for the Jussiape II granite sample is $3.21 \mathrm{Ga}$ (with a $\mathrm{DM}_{0}=+10$ ). Epsilon value at $2.1 \mathrm{Ga}$ was defined as -10.3 , which suggests that the Jussiape II granite was derived from the melting of the surrounding Archean basement, an interpretation that is in agreement with the presence of inherited zircon grains in the granite. Regarding the Humaitá granodiorite, the Sm-Nd model age obtained is ca $2.76 \mathrm{Ga}$ (Tab. 3), with an epsilon $\mathrm{Nd}$ value of -4.0 at $2.1 \mathrm{Ga}$. The model age obtained for sample SCP-1351 (Belo Campo granodiorite) is ca $3.28 \mathrm{Ga}$ (Tab. 3), with epsilon Nd value of -15 at $2.03 \mathrm{Ga}$. This result and the presence of inherited zircon grains are both indicative of a large crustal reworking process in the genesis of this granitoid. In addition, regarding the Broco granodiorite sample, the $\mathrm{Nd}$ model age obtained is ca $2.8 \mathrm{Ga}$ (Tab. 3), with epsilon Nd value of -6.3 at $2.1 \mathrm{Ga}$. A $\square_{\mathrm{Nd}}$ evolution diagram for granitoid samples is shown in figure 7 , in which the isotopic growth lines for the five samples were plotted in the evolution field defined for Archean gneisses of the Gavião Block by Santos-Pinto et al. (2012) and Barbosa et al. (2013).

\section{Figure 7}


New geochemical data are presented for the Jussiape II, Lagoa das Almas, Humaitá, and Broco granitoids (Tabs. 4 to 7).

Less differentiated samples were found in the Jussiape II and Broco granitoids (Fig. 8). Regarding the other four studied granitoids, a lower variation of $\mathrm{SiO}_{2}$ was observed for all samples of the Humaitá granitoid and the majority are strongly differentiated, with $\mathrm{SiO}_{2}$ contents higher than $70 \mathrm{wt}$ \%. The aluminum is variable for the Lagoa das Almas and Jussiape II granitoids, but for the Humaitá and Broco granitoids this element varied varies little. In the Harker diagrams (Fig. 8), the contents of $\mathrm{K}_{2} \mathrm{O}$ and $\mathrm{Rb}$ increase with the growth of $\mathrm{SiO}_{2}$ for all the studied granitoids except Broco. This behavior was also observed for $\mathrm{Ga}$ and $\mathrm{Nb}$ in the Lagoa das Almas granitoid and for $\mathrm{Nb}$ in the Jussiape II granitoid. There is a general decrease in the contents of other elements when there is an increase of $\mathrm{SiO}_{2}$ (Fig. 8). The Humaitá granitoids display very low values of $\mathrm{TiO}_{2}$ and $\mathrm{Fe}_{2} \mathrm{O}_{3}$ in comparison to the other studied granitoids. Similar to what was interpreted by Teixeira et al. (2015), the low contents of these elements in the Humaitá granitoid may suggest that Ti- and Fe-rich minerals represent the refractory phases during the partial melting for the formation of the magma that generated these rocks. In this situation, $\mathrm{Ti}$ is largely retained in ilmenite, sphene, or rutile in the protolith.

\section{Figure 8}

Regarding the Fe-index, the samples from the Jussiape II and Humaitá granitoids are distributed both in the field of ferroan rocks, as well as in the field of magnesian rocks. However, the samples of the Lagoa das Almas and Broco granitoids are predominantly magnesian (Fig. 9a). Considering the MALI index (Fig. 9b), the Jussiape II samples plot in the field of alkali and alkali - calcic rocks, while the samples from the Lagoa das Almas granitoids are distributed broadly across the diagram. On the other hand, the samples from the Humaitá granitoids were plot in the field of calcic and calc-alkalic rocks, while the Broco granite samples plot in the calc-alkalic field.

Figure 9 
The Jussiape II (A/CNK = 0.95 to 1.20), Lagoa das Almas (A/CNK = 1.0 to 1.20$)$ and

Broco ( $\mathrm{A} / \mathrm{CNK}=1.03$ to 1.31 ) granitoids present $\mathrm{K}_{2} \mathrm{O} / \mathrm{Na}_{2} \mathrm{O}$ ratios higher than 1 . The Humaitá granodiorite display most $\mathrm{K}_{2} \mathrm{O} / \mathrm{Na}_{2} \mathrm{O}$ ratios lower than 1 and $\mathrm{A} / \mathrm{CNK}$ varies from 0.99 to 1.11(Fig. 9c). The normative corundum varies from 1.78 to $2.98,2.21$ to $4.2,0.54$ to 6.58 and 3.37 to 7.14 for the Jussiape II, Lagoa das Almas, Humaitá and Broco granitoids, respectively. The REE patterns (Fig. 10a-d) show fractionation of the LREEs in relation to the HREEs. The $\mathrm{La} / \mathrm{Yb}_{\mathrm{N}}$ ratios range between 21.9-51.9 and 10.04-98.02 for the Jussiape II and Lagoa das Almas granodiorites, respectively. For the Humaitá and Broco granitoids, this ratio varies between 9.78-32.59 and 9.71-77.70, respectively, reflecting less fractionation of the REEs of the Humaitá granodiorite when compared to the other granites of this study. A negative Eu anomaly is observed for all rocks, though it is less intense for the Humaita and Broco granodiorites.

Spider diagrams (Fig. 10e-h) are marked by LILE (Rb, Th, Ba) enrichment in all the granitoids studied. The Lagoa das Almas and Humaitá granitoid samples, as well as some samples of the Jussiape II granitoid, yield negative Ta and $\mathrm{Nb}$ anomalies. HFSEs, particularly $\mathrm{Zr}, \mathrm{Tb}$, and $\mathrm{Y}$, are depleted in these rocks.

Figure 10

When compared to the classic calc-alkalic granitoids of Best (2003), some samples of the Jussiape II granite exhibit high contents of incompatible elements (Tab. 4), especially HFSEs, such as Ta (18 to $30 \mathrm{ppm}$ ). The concentration of Ba varies between 178 and $559 \mathrm{ppm}$ and the total REEs between 227.35 and $1178.38 \mathrm{ppm}$. Some samples yield F contents >300 ppm. The Lagoa das Almas and Humaitá granitoids, on the other hand, exhibit low contents of incompatible elements (Tabs. 5, 6), especially HFSEs such as $\mathrm{Ta}$ and $\mathrm{Nb}$. Most of the samples of the Humaitá granitoid present content of less than 10 ppm of these elements. However, this granitoid presents a high content of LILE, such as Ba (951-1502 ppm). Regarding the Humaitá granitoid, most of the samples yield low F contents ( $<300$ ppm), but considering the Lagoa das Almas granitoid some samples reached values higher than 1,300 ppm.

The intraplate setting is delimited in the Pearce (1996) diagram (Figs. 9d, e). Some Jussiape II samples plot in the intraplate field, whereas other Jussiape II samples and the Broco and Lagoa das Almas granitoid samples plot in the field of post-collisional granites. 
Most of the Humaitá granitoid samples plot in the magmatic arc field, which is corroborated by their chemical characteristics, such as being sodic and calcic to calc-alkalic with a relatively lower K. Although the Lagoa das Almas granodiorite samples in figure 9d plot in

\section{Integration of the Petrography, Geochronology and Geochemical data of the} Paleoproterozoic Granitoids in the Southern Gavião Paleoplate

This section presents the results of the integration of the new petrography, geochronology and geochemistry data reported in the present study for the Jussiape II, Lagoa das Almas, Humaitá, Belo Campo and Broco granitoids to the data of the Siderian, Rhyacian and Orosirian granitoids of the southern sector of the Gavião Paleoplate, which were compiled from the references presented in tables 1 and 8, as well as in Barbosa et al. (2012). The geochemical data gathered from the literature were integrated to the results reported in the present study when obtained by means of similar methodologies. To perform this integration, the initial step was to separate the granitoids with similar chemical signatures. Then, geochronology and petrography data were compared, individualizing distinct groups of granitoids. Finally, the spatial distribution of the identified groups was observed. The main objective was to identify distinct magmatic suites (Groups) and observe the tectonic meaning of each one.

Based on the geochronology data of table 1 and on the presence or not of deformational structures, the twenty nine granitoids of the southern sector of the Gavião Paleoplate were separated into two main groups (Figs. 2, 11 and Tab. 1): Group 1, or Bom Sucesso Suite, comprising plutons with variable intensities of solid state deformation and that are older than $2.09 \mathrm{Ga}$. This group is represented by the Veredinha, Ibitiara-Queimada Nova, Aracatu, Lagoa das Almas, Humaitá, Rio do Paulo and Jussiape I granitoids. Granodiorites predominate, but tonalitic and monzogranitic rocks, and quartz-monzodioritic and quartzdioritic enclaves can also be found (Fig. 12). The rocks vary between leucocratic and mesocratic with biotite and amphibole. Zircon, apatite, allanite, magnetite and titanite are the 
accessory phases; and (ii) Group 2 is younger than 2.09 Ga and comprises granitoids with

little or no deformation. Based on petrography (Fig. 12) and geochemical data (Figs. 13 to 17 and tab. 8), Group 2 was divided into four subgroups, or distinct magmatic suites: (i) Group 2a, which comprises the Guanambi Suite, with U-Pb ages ranging from 2.06 to $2.04 \mathrm{Ga}$, composed of multiple intrusions of the Urandi-Guanambi batholiths and by the Boquira, Estreito, Cara Suja and Ceraíma massifs. This subgroup is composed of multiple intrusions of syenites and monzonites with subordinate granitic and mafic rocks (Fig. 12) (Rosa, 1999 and Teixeira, 2000), corresponding to an area of approximately $6,000 \mathrm{~km}^{2}$. According to Rosa (1999), these rocks vary from leuco- to mesocratic and present biotite or phlogopite, diopside, edenite, pargasite, or hornblende. The accessory mineralogy is represented by variable proportions of apatite, zircon, ilmenite, magnetite, titanite, allanite, monazite, fluorite, molybdenite and pyrite. The presence of normative quartz suggests that the majority of the rocks is silica-saturated, except for the foid-syenitic and foid-monzonitic terms; (ii) Group 2b, dated at 2.05-2.01 Ga (U-Pb), is composed of rocks of the Caculé, Jussiape II and Santa Isabel granitoids. This subgroup comprises, mainly, monzogranites and syenogranites with minor quartz-syenite and quartz-monzonite (Fig. 12) with hornblende e/or biotite. Leucocratic rocks and porphyritic facies predominate. Angular xenoliths of host orthogneisses are also found. Zircon, titanite, magnetite, monazite and apatite are accessory minerals. (iii) Group 2c presents $\mathrm{U}-\mathrm{Pb}$ age varying between 2.05 and $1.8 \mathrm{Ga}$ and is represented by the Iguatemi, Riacho das Pedras, Serra da Franga and Pé do Morro massifs. This subgroup presents syenogranites with subordinate monzogranites (Fig. 12). Biotite can be found in these rocks. The accessory mineralogy is composed of titanite, zircon, apatite, allanite and monazite; and (iv) Group 2d, with U-Pb ages ranging between 2.05 and 1.9 Ga (Fig. 11, tab. 1), presents rocks of the Umburanas, Mariana, Espírito Santo, Lagoa Grande-Lagoinha, Gameleira, Caetano-Aliança, Campo do Meio, Broco and Piripá granitoids. This subgroup corresponds to granodiorites and monzogranites (Fig. 12). The accessory mineralogy is composed of apatite, magnetite, ilmenite, allanite, biotite, muscovite, zircon and monazite. Garnet, tourmaline and cordierite were also found.

The rocks of groups $2 \mathrm{c}$ and $2 \mathrm{~d}$ are spatially associated with the metavolcanosedimentary sequences of the Gavião Paleoplate. Stromatic migmatites generated from the partial melting of metassedimentary rocks are the host rocks of these granitoids. These granitoids are diatexites and may present nebulite and schlieren structures. 
A superposition of ages occurs among groups $2 \mathrm{a}, 2 \mathrm{~b}, 2 \mathrm{c}$ and $2 \mathrm{~d}$, in which group $2 \mathrm{a}$

presents the smallest age variation and group 2c presents the youngest granitoids (Tab. 1 and fig. 11).

\section{Figure 11}

With the exception of the granitoids of Group 1, that show deformational foliation and, in some cases, gneissic banding, these massifs are generally isotropic and magmatic flow is sometimes visible. In the field, the contacts between the granitoids of groups $1,2 \mathrm{a}$ and $2 \mathrm{~b}$ with Archean orthogneisses are abrupt. On the other hand, stromatic migmatites represent the host rocks of the granitoids of groups $2 \mathrm{c}$ and $2 \mathrm{~d}$. Transitional contacts between the granitoids of these groups and the migmatites are frequently observed. Thus, the granitoids of these two groups are better characterized as diatexites (Sensu Sawyer 2008).

\section{Figure 12}

The distribution of the petrography data for all the groups allows the distinction of magmatic differentiation trends by Lameyre and Bowden (1982) (Fig. 12), from rocks with a calc-alkaline-trondhjemitic (low K) trend (Group 1) to rocks with an alkaline and peralkaline trend (Group 2a). The granitoids of Group 2b were plotted in the calc-alkaline-granodioritic (medium K) field and the plutons of groups $2 \mathrm{c}$ and $2 \mathrm{~d}$ were mainly plotted in the field of granitoids formed by crustal melting.

Table 8 presents a synthesis of the chemical data for the individualized groups through their means (M) and standard deviations (SD). The supplementary material of chemical data is presented in appendix 1 through 4 . The rocks that are poorer in $\mathrm{SiO}_{2}$ belong to groups $2 \mathrm{a}$ and $2 \mathrm{~b}$, while the other groups generally present contents of $\mathrm{SiO}_{2}$ higher than $65 \%$. Harkerlike diagrams for major, compatible, LIL and HFS elements are shown in figures 13 and 14. All of the groups identified show a decrease in major elements content with the enrichment of $\mathrm{SiO}_{2}$, with the exception of $\mathrm{K}_{2} \mathrm{O}$ and $\mathrm{Na}_{2} \mathrm{O}$, whose concentrations increase with the differentiation trend. This behavior suggests that the fractionation of calcic plagioclase, apatite, titanite, hornblende, biotite and magnetite controls $\mathrm{TiO}_{2}, \mathrm{P}_{2} \mathrm{O}_{5}, \mathrm{CaO}, \mathrm{MgO}$ and $\mathrm{FeO}_{\mathrm{t}}$ contents. The values of $\mathrm{P}_{2} \mathrm{O}_{5}$ can be explained by the presence of apatite in all groups. Regarding the trace elements (Fig. 14), the results show a progressive decrease of $\mathrm{Sr}, \mathrm{Ba}, \mathrm{Zr}$, 
$\mathrm{La}$ and $\mathrm{Y}$, and an increase of $\mathrm{Nd}$ concentrations with the growth of $\mathrm{SiO}_{2}$, although a relative increase of $\mathrm{Sr}$ and $\mathrm{Ba}$ was observed in Group 1. The presence of allanite and zircon during the initial phases of crystallization can explain this behavior for all groups.

Figure 13

Figure 14

When comparing the average concentration of major and trace elements for five individualized groups (Tab. 8), moderate values of Ba were observed for Group 1, moderate values of $\mathrm{Sr}, \mathrm{Ba}, \mathrm{Zr}$ and total REE were observed for Group 2a, while Group $2 \mathrm{~b}$ presented high values of Th and total REE. The values of $\mathrm{Rb}$ for Group $2 \mathrm{c}$ were particularly noteworthy, with the highest values among all groups. In groups $1,2 \mathrm{~b}, 2 \mathrm{c}$ and $2 \mathrm{~d}$, rocks with $\mathrm{A} / \mathrm{CNK}$ greater than 1 predominated, while in Group $2 \mathrm{a}$, rocks with $\mathrm{A} / \mathrm{CNK}$ lower than 1 predominated. In general, the $\mathrm{K}_{2} \mathrm{O} / \mathrm{Na}_{2} \mathrm{O}$ ratio is greater than 1 and Group 2a have the greatest values.

The rocks from all groups were predominantly potassic, although some samples plotted in the field of sodic rocks (Fig. 15a). Figure 15b shows that the rocks of Group 1 are predominantly subalkaline, while the rocks of groups $2 \mathrm{a}$ and $2 \mathrm{~b}$ plot dominantly in the field of alkaline rocks. The remaining groups are distributed in both fields.

Figure 15

In the $\mathrm{K}_{2} \mathrm{O}-\mathrm{SiO}_{2}$ the granitoids of Group 1 plot mainly in the fields of medium- and low-K series, while the rocks of Group $2 \mathrm{a}, 2 \mathrm{~b}$ and $2 \mathrm{c}$ plot mainly in the field of high-K series (Fig. 15c). Group $2 \mathrm{~d}$ is distributed between the fields of high- and medium-K series. The granitoids of groups 1 and $2 d$ plot in the ferroan and magnesian fields (Fig. 15d). The granitoids of Group 2a are predominantly magnesian, while the granitoids of groups $2 \mathrm{~b}$ and $2 \mathrm{c}$ are predominantly ferroan. Regarding the MALI index (Fig. 15e), the granitoids of Group 1 are predominantly calcic to calc-alkalic, while the rocks of Group 2a are mainly alkali-calcic to alkali. On the other hand, the granitoids of Group $2 \mathrm{~b}$ plot mainly in the alkali-calcic field. Comparing the spatial distribution of the calc-alkalic to calcic and the alkali to alkali-calcic granitoids in figure 2, the intrusions of Group 1, which are calc-alkalic to calcic, occur to the 
east, while the rocks of Group $2 \mathrm{a}$, alkali to alkali-calcic, occur in the western sector of this figure.

Chondrite-normalized REE patterns are presented in figure 16 (a-e). As a whole, the groups show REE patterns characterized by: (i) highly fractionated light/heavy REE ratios $\left(\mathrm{La}_{\mathrm{N}} / \mathrm{Yb}_{\mathrm{N}} \geq 15\right.$ up to 90 , Fig. 16a to f) for groups $1,2 \mathrm{a}, 2 \mathrm{~b}$ and $2 \mathrm{~d}$ and low fractionated light/heavy REE ratios $\left(\mathrm{La}_{\mathrm{N}} / \mathrm{Yb}_{\mathrm{N}}<15\right.$, Fig. 16 a to f) for Group $2 \mathrm{c}$ and for most of the samples of Group 2d; (ii) there is an increase of $\mathrm{La}_{N} / \mathrm{Yb}_{\mathrm{N}}$ with the increase of the sum of REE (Fig. 16f); and (iii) negative europium anomalies, though some positive anomalies are observed in Group 2a (Figs. 16a to e and $16 \mathrm{~g}$ ). The samples of groups 1 and $2 \mathrm{~b}$ show a flat HREE pattern. Although the Eu anomaly is negative in all groups, in Group 2a it is more subtle, suggesting less fractionation of feldspar in relation to the other groups. Regarding the sum of REE (Figs. 16f, g), most analyses of Group 1 are below 500 ppm, but some samples of this group present values above 1,500 ppm. The highest values are generally those of Group 2a. Table 8 informs average composition of the different groups of rocks. Although there is a REE similarity pattern between groups 1 and $2 \mathrm{~b}$, the main distinction, besides age, is the greater enrichment in LILE and HFSE of the granitoids of Group $2 b$ in comparison to Group 1, as well as the sum of REE (Tab. 8 and appendix 2, 3).

Figure 16

In the ORG-normalized diagrams (Fig. 17), the groups exhibit the following common characteristics: (i) negative slopes from LILE to HFSE; (ii) negative spikes of $\mathrm{Nb}-\mathrm{Ta}$ relative to their neighboring elements, which is a characteristic of arc settings; and (iii) enrichment of Th relative to $\mathrm{Ba}$, of $\mathrm{Rb}$ relative to $\mathrm{K}_{2} \mathrm{O}$ and of Ce relative to $\mathrm{Nb}$. $\mathrm{Rb}$ is enriched relative to $\mathrm{Ba}$ for groups $2 \mathrm{c}$ and $2 \mathrm{~d}$. For the remaining groups, $\mathrm{Rb}$ was either enriched or depleted relative to Ba. For groups 1 and 2a the values of $\mathrm{Cr}$ reach 362 and 500 ppm, respectively (Appendix 2). These values are much above those of the other groups.

Figure 17

Regarding the tectonic environment, the diagrams of figure 18a-e show a clear association between the Siderian-Rhyacian-Orosirian granitoids of the southern sector of the Gavião Paleoplate and magmatic arc and post-collisional environments. These results 18 
corroborate those shown in figure 17. This figure shows that the curve of the volcanic arc granites of Chile by Pearce et al. (1984) adjusts to the data of all samples of the groups studied. Moreover, the post-collision granite curve by Pearce et al. (1984) also adjusts to the curve of the granitoids of groups $2 \mathrm{c}$ and $2 \mathrm{~d}$.

Figure 18

\section{Discussion}

Amalgamation of four main paleoplates, Gavião, Serrinha, Jequié and Uauá, occurred in the NE sector of the São Francisco Craton during the Siderian to Orosirian. As described firstly by Barbosa and Sabaté $(2002,2004)$, the Gavião Paleoplate behaved as the foreland of the Itabuna-Salvador-Curaçá orogen. However, the neosome ages of 2,250 $\pm 2 \mathrm{Ma}, 2,095 \pm 9$ Ma and 2,032 \pm 14 Ma, obtained by Barbosa et al. (2013; zircon, LA-ICPMS), Medeiros (2013; zircon, LA-ICPMS and SHRIMP), and Barbosa and Cruz (2011; zircon, LA-ICPMS), respectively, suggest the existence of three migmatization events in the Gavião Paleoplate between the Rhyacian and the Orosirian. This interpretation takes into account the existence of granulites in this sector of the southern Gavião Paleoplate and the vergence located southeastwards of earlier deformations recorded in these rocks and associated with granulitization. These data provide clues regarding the effective participation of the Gavião Paleoplate in collisional processes of the four paleoplates that included continental margin reworking from the Itabuna-Salvador-Curaçá Belt to the West Central African Belt.

Geochronological and geochemical data of 28 granitoids available from the southern sector of the Gavião Paleoplate led to the identification of a group of rocks older than 2.09 $\mathrm{Ga}$, which were generally deformed, with crystallization ages varying between 2,380 and $2,113 \pm 11 \mathrm{Ma}$ (Group 1, present study), and another group younger than $2.09 \mathrm{Ga}$, which was not deformed, with crystallization ages varying between 2,066 \pm 37 and 1,852 $\pm 50 \mathrm{Ma}$ (Group 2, present study). The model ages can be grouped as follows: 3.6 to $3.3 \mathrm{Ga}$ for the Aracatu (Group 1), Iguatemi (Group 2c), Mariana (Group 2d) and Umburanas (Group 2d) massifs; 3.3 to $3.1 \mathrm{Ga}$ for the Jussiape II (Group 2b), Riacho das Pedras (Group 2c), Iguatemi (Group 2c) and Espírito Santo (Group 2d) massifs; 2.9 to 2.6 for the Humaitá (Group 1), Guanambi Urandi Multiple Intrusions (Group 2a), Cara Suja (Group 2a), Ceraíma (Group 2a), Estreito (Group 2a) and Caculé (Group 2b) massifs (Tab. 1); and ca 2.6 to 2.4 Ga for the CaetanoAliança, Lagoa Grande-Lagoinha and Gameleira massifs (Group 2d) (Tab. 1). The available 
$\mathrm{Nd}$ isotopes with Archean model ages and negative values of epsilon (Tab. 1, Fig.19) all indicate the important participation of Archean crust in the formation of the granitoids of groups 1 and 2. The younger model ages would suggest mixing between an Archean crustal source and a possible juvenile source of ca $2.0 \mathrm{Ga}$.

\section{Figure 19}

Santos Pinto (1996) performed geochemical modeling of major elements and REE and proposed the melting of Archean crustal rocks as the source for the following granites: Aracatu (Group 1, partial melting product of $3.33 \mathrm{Ga}$ Archean grey gneisses), Mariana (Group 2c, partial melting product of Archean orthogneisses with a minimum age of $3.26 \mathrm{Ga}$ ) and Umburanas (Group 2d, partial melting product of Archean tonalites of the granite host rocks). Furthermore, in the Aracatu granite (Group 1), an inherited zircon core provided a slightly discordant ${ }^{207} \mathrm{~Pb} /{ }^{206} \mathrm{~Pb}$ SHRIMP age of ca $3.25 \mathrm{Ga}$ (Santos Pinto et al., 2012), which is considered as the minimum age for inheritance from an Archean gneissic source. In the Umburanas massif (Group 2c), inherited zircon grains were found with ages between 2.7 and 3.1 Ga (Santos Pinto, 1996; Santos Pinto et al., 1998). Bastos Leal et al., (2000) also indicated an anatexis origin for the Archean gneissic-migmatitic rocks of the Gavião Paleoplate, with contamination of upper crust material from the Iguatemi (Group 2c) and Espírito Santo (Group 2d) massifs. The processes involving assimilation/crustal contamination may have been responsible for collecting these crystals from the host rocks.

The regional distribution of groups 1 and 2a (Fig. 2) shows the existence of calcic to calc-alkalic (sensu Frost et al., 2001) granitoids older than 2.09 Ga in Group 1, in the eastern sector of the southern region of the Gavião Paleoplate, and alkali to alkali-calcic, ultrapotassic to shoshonitic granitoids with ages between 2.05 to 2.04 in the western sector (Group 2a). The chemical characteristics of these rocks and their distribution indicate the existence of a Siderian-Rhyacian subduction zone situated in the eastern portion of the southern domain of the Gavião Paleoplate.

By integrating the chemical and geochronological data presented in this study with those published in the literature (see references in tables 1 and 8), as well as data associated with metamorphism and regional deformation obtained by Barbosa and Cruz (2011), Medeiros (2013) and Cruz et al. (2014a), it can be suggested that the Siderian-RhyacianOrosirian granitogenesis in the southern region of the Gavião Paleoplate possibly developed 
through the following steps (Fig 20): (i) between 2.38 and 2.1 Ga the magmatic arc was

installed on the eastern continental margin of the Gavião Paleoplate and a subduction zone also developed to the west, producing calcic to calc-alkalic granitic rocks of Group 1 with a maximum age obtained for the pre-collisional granitoids of $2.38 \mathrm{Ma}$ (Aracatu granitoid). This body should represent the initial stage of formation of the Western Bahia Magmatic Arc, with intense participation of the continental crust; (ii) collision between the Gavião and Jequié paleoplates, metamorphism between 2.1 and $2.09 \mathrm{Ga}$ with syn-collisional migmatization, recorded by Medeiros et al. (2011). This migmatization is associated with the formation of metatexites and diatexites, though plutons of this age have not yet been found. In case they have existed, they were possibly positioned in the uppermost areas of the crust, removed either by tectonic processes or by erosion. Currently, deeper crustal levels crop out and, perhaps due to this, larger bodies are not found; (iii) from 2.06 to 2.03 there was the crystallization of the alkali to alkali-calcic granitoids of Group 2a, which were late-collisional and ultrapotassic; anatexis associated with the melting of igneous continental crust and crystallization of the alkali-calcic to alkali granitoids of Group 2b; (iv) from 2.03 to $1.9 \mathrm{Ga}$ there was a broad anatexis associated with the melting of igneous continental crust and metavolcanosedimentary rocks, as well as crystallization of the granitoids of groups $2 \mathrm{c}$ and 2d. Continental collision of Archean terranes of the Gavião and Jequié paleoplates led to crustal thickening and reworking with the generation of Orosirian-Rhyacian granitoids in a subduction model far from the subduction zone, as described by the crustal derived magma of the Cordilleran-granite type. If this model is applied, the granitogenesis associated with the generation of granitoids in the southern region of the Gavião Paleoplate occurred during a prolonged oceanic crust subduction period and in a context of a long-lived convergence/collision of two Archean masses.

Figure 20

Mascarenhas (1979), Rosa et al. (1996) and Rosa (1999) had already suggested the presence of a Paleoproterozoic belt and a magmatic arc in the region between Guanambi and Caetite (Fig. 1) without, however, defining the polarity of the subduction zone. Mafic metavolcanic rocks with crystallization age of 2,218 \pm 18 Ma (Rodrigues et al., 2012) corroborate the interpretation of a Paleoproterozoic magmatic arc in this sector of the Gavião Paleoplate. Mafic to intermediate rocks with magmatic arc signature, which are intercalated 
with metagraywackes with maximum age of 2.5 Ma have also been reported by Vitória (2014). Moreover, the existence of granulitic migmatites (Arcanjo et al., 2005; Barbosa et al., 2011, 2013) and related reworking of the Archean crust (Santos Pinto et al., 1998, 2012) may be a further argument for the existence of continental collisions in this sector of the Gavião Paleoplate. The metamorphism age of 2,250 $\pm 2 \mathrm{Ma}$ obtained in the region of Riacho de Santana (Fig. 2) by Barbosa et al. (2013) is probably related to early collisions between the

Gavião Paleoplate and another paleoplate located northwestwards. This interpretation considers the existence of granulites in this sector of the southern Gavião Paleoplate and of

the vergence located to the southeast of the earlier deformations recorded in these rocks, associated with granulitization. These ages that represent an older Rhyacian metamorphism in the Gavião Paleoplate are similar to those obtained by Ávila et al. (2008) for the first metamorphism event of the Mineiro Belt. A detailed geological study of the Gavião Paleoplate, especially stratigraphic and isotopic study of the metavolcanosedimentary sequences, can contribute to a better delimitation of the tectonic plates involved in this collisional scenario, as well as lead to a better understanding of the architecture of the orogenic system.

Some petrogenetic aspects can be discussed based on the chemical data of the major and trace elements found in granitoids of groups $1,2 \mathrm{~b}, 2 \mathrm{c}$ and $2 \mathrm{~d}$. As interpreted by Ávila et al. (2014), the positive correlation between $\mathrm{K}_{2} \mathrm{O}$ and $\mathrm{Ba}$ (Fig. 13m) for the granitoids of groups $1,2 \mathrm{~b}, 2 \mathrm{c}$ and $2 \mathrm{~d}$ may suggest crystallization control by biotite and K-feldspar for these granitoids, while the positive correlation between $\mathrm{CaO}$ and $\mathrm{Sr}$ (Fig. 13n) for all groups may suggest crystallization control by plagioclase and apatite. Moreover, the negative correlation between $\mathrm{Zr}$ and $\mathrm{SiO}_{2}$ in all groups (Fig. 14i) indicates that zircon was fractionated during the initial phase of the melt crystallization, as interpreted also by Ávila et al. (2014). The negative $\mathrm{Eu}$ anomaly of the diagrams in figure 16a-d suggests that plagioclase was also a residual phase. In all the individualized groups, the negative $\mathrm{Nb}$ anomalies of figure $17 \mathrm{a}$-e could be explained by the presence of sphene, ilmenite, rutile or amphibole as residual minerals in the protolith (Ávila et al., 2014, Teixeira et al., 2015). The low content of this element reflects the absence of rutile and ilmenite, and the sparse presence of amphibole in the rocks of all groups. In turn, low Y values may suggest that garnet and xenotime were also residual phases in the source of the magmas that originated the granitoids of all groups.

Groups 1 and 2a have high values of $\mathrm{Rb}, \mathrm{Ba}$ and $\mathrm{Zr}$. Rb presents positive correlation with $\mathrm{SiO}_{2}$, but $\mathrm{Ba}$ and $\mathrm{Zr}$ present negative correlation with this oxide (Fig. 14). This negative 
correlation may be related to an originally enriched magmatic source (Martin et al., 2010), since there was no incompatible behavior for these two elements. These geochemical attributes associated with the arc signature of the rocks in Group 1, as well as the values of $\varepsilon_{\mathrm{Nd}}$ and the $\mathrm{T}_{\mathrm{DM}}$ age of the Humaita granodiorite (Table 3, Group 1) suggest that participation of Archean continental crust may have been a predominant factor in the formation of the granitoids of these groups. Alternatively, the participation of a metasomatized mantle wedge above a Paleoproterozoic subduction zone cannot be discarded. In a subduction environment, fluids derived from slab dehydration and/or slab-derived melts may enrich the mantle wedge in LILE ( $\mathrm{K}, \mathrm{Rb}, \mathrm{Sr}, \mathrm{Ba})$, light REE and highly incompatible HFSE (Plank and Langmuir, 1998, Martin et al., 2010; Rapp et al., 2010, Seixas et al., 2013). One hypothesis for mantle metasomatism participation for the granitoids in Group 2a was also suggested by Rosa (1999), considering the association of these rocks with the magmatic arc environment and the negative values of $\square_{\square \mathrm{d}}$ for these rocks.

Figure 21 compares the geochronological data of the granitoids of groups 1 and 2 presented in this paper with those produced by Rios et al. (2008, 2009 and authors cited therein) for the Serrinha Paleoplate; by Silva et al. (2002b) and Ávila et al (2010, 2014 and authors cited therein), Seixas et al. (2012, 2013 and authors cited therein), Teixeira et al. (2015 and authors cited therein) and Nunes (2007) for the Mineiro Belt; by Silva et al. (2002b) and Noce et al. (2007) for the Mantiqueira Complex and by Thieblemont et al. (2009 and authors cited therein) for the Eburnean granitoids of Gabon. The granitogenesis of the tectonic domains illustrated in figure 20 reflects a diachronic soft accretion/collision event (sensu Cordani et al., 2000, among others). In the Mineiro Belt and in the southern sector of the Gavião Paleoplate the earliest arc magmatism is marked by the granitoids of the Lagoa Dourada and Rio do Paulo/Aracatu suites, respectively, with Siderian ages. Granitogenesis between 2.23 and 2.13 Ga was identified in the Mineiro Belt by Ávila et al. (2010, 2014), but igneous representatives of this age have not yet been reported in the Western Bahia Magmatic Arc. A concordant age at 2,250 \pm 23 Ma was found in a zircon core of the Lagoa das Almas granitoid (Fig. 5c). In turn, ages between 2.13-2.10 were obtained for the granitoids of the Western Bahia Magmatic Arc (see references of table 1), as well as for the Mineiro Belt (Seixas et al., 2012, 2013 and authors cited therein), the Mantiqueira Complex (Noce et al., 2000, 2007 and authors cited therein) and the Serrinha Paleoplate (Rios et al., 2008, 2009 and authors cited therein). 
Figure 22

A comparison between the isotopic $\varepsilon_{\mathrm{Nd}}(2.2-2.0 \mathrm{Ga})$ data of the Mineiro Belt granitoids and the Gavião Paleoplate is presented in figure 23. Based on Noce et al. (2000), regarding this isotopic parameter, two groups of granitoids were individualized. The granitoids of groups 1, 2a, 2b, 2c and 2d were plotted in Group A, as proposed by Noce et al. (2000). According to these authors, the samples of this group are characterized by an inherited crustal signature with a wider range of $\varepsilon_{\mathrm{Nd}(2.2-2.0 \mathrm{Ga})}$ values. On the other hand, samples from Group B tend to have a narrow range of $\varepsilon_{\mathrm{Nd}}(2.2-2.0 \mathrm{Ga})$ values, implying the presence of Rhyacian juvenile accretion. Granitoids of both groups were identified in the Mineiro Belt, particularly the 
Maranhão tonalite with crystallization age of 2,128 9.9 Ma and values of $\varepsilon_{\mathrm{Nd}}(2130 \mathrm{Ga})$ varying from -1.0 to +0.9 (Seixas et al., 2013). This granitoid presents crystallization age near the crystallization age of the Humaitá and Lagoa das Almas granitoids. Moreover, the REE spectrum is similar to that of the granitoids of Group 1 (Fig. 16a). However, the values of $\varepsilon_{\mathrm{Nd}}$ suggest a lower participation of the continental crust in the genesis of the Maranhão tonalite in relation to the granitoids of Group 1. This variation suggests distinct sources for the regions and different degrees of interaction between mantle-derived magmas and continental crust for these granitoids. As suggested for the Humaitá Granitoid, one participation hypothesis for the enriched mantle in the genesis of the precursor magma for the Maranhão Granitoid was offered by Seixas et al. (2013).

Figure 23

\section{Conclusions}

Based on what was presented and discussed, we conclude the following:

(a) The U-Pb (zircon, LA-ICPMS) ages obtained for Jussiape II, Lagoa das Almas, Humaitá, Belo Campo and Broco granitoids are 2,052 \pm 43, 2,114 \pm 24, 2,140 \pm 9, 2,049 \pm 23 and $2,038 \pm 8 \mathrm{Ma}$, respectively. The $\square_{\square \mathrm{d}}$ values for these granitoids are, respectively, -10.3, $15.4,-4.0$ and -6.3 . These values suggest variable proportions of involvement of the continental crust in the formation of these rocks.

(b) Twenty-nine Siderian-Rhyacian-Orosirian granitoids were recognized in the southern Gavião Paleoplate. The whole set of geochemical and geochronological data for these granitoids allowed the individualization of five groups, or five magmatic suites. The crystallization ages varied from 2,380 to $2,091 \pm 6.6 \mathrm{Ma}, 2,054-6 /+8$ to $2,041 \pm 23 \mathrm{Ma}$, $2,066 \pm 37$ to $2,019 \pm 32 \mathrm{Ma}, 2,058 \pm 8$ to $1,852 \pm 50 \mathrm{Ma}$ and $2,049 \pm 12$ to $1,929 \pm 16 \mathrm{Ma}$ for groups 1, 2a, 2b, 2c and 2d suites, respectively. In general, the granitoids of Group 1 presented varied intensities of deformation, while the granitoids of the remaining groups were generally not deformed. Additionally, the granitoids of groups $2 \mathrm{c}$ and $2 \mathrm{~d}$ are associated with domains of intense rock migmatization. For the granitoids of groups $2 a$ and $2 b$, this association are not clear.

(c) Group 1 includes mainly calcic to calc-alkalic rocks, with low to medium potassium. The tectonic environment interpreted for the rocks of this group is a magmatic arc. Group $2 \mathrm{a}$ is formed predominantly of alkali-calcic to alkali granitoids with ultrapotassic to 
shoshonitic rocks. The rocks rocks plot in the field of the post-collisional granitoids, but the trace element signature, especially $\mathrm{Nb}$ and $\mathrm{Ta}$, suggests association with a magmatic arc environment. An increase in alkalinity from the west to the east was observed when comparing the spatial distribution of the intrusions of groups 1 and 2a. This geochemical trend between the granitoids of groups 1 and 2a suggests a cordilleran environment with subduction to the west.

(d) The geochronological and geochemical data set may suggest the following model in the western portion of the paleoplate: (i) 2.38-2.12 Ga- a magmatic arc (Western Bahia Magmatic Arc) was installed, with the subduction zone dipping westward, producing calcic to calc-alkalic granitic Group 1; (ii) 2.1 and 2.09 Ga- syn-collisional migmatization; (iii) 2.06 to 2.04- crystallization of alkali to alkali - calcic granitoids of Group 2a and of alkali - calcic to alkali granitoids of Group 2b; (iv) 2.04 to 1.8- large anatexis associated with the melting of continental crust and metavolcanosedimentary rocks and the crystallization of the granitoids of groups $2 \mathrm{c}$ and $2 \mathrm{~d}$.

(e) $\square_{\square \mathrm{d}}(\mathrm{t})$ values are negative, varying between -4.0 and -15.4 , for the individualized groups, which can be interpreted as a result of melting or reworking of the Archean continental crust. Considering the magmatic arc system, some contribution from a metasomatized mantle can be suggested for the formation of these rocks, particularly the Humaitá granitoid, presented in this study.

(f) Comparing the granitogenesis of the Western Bahia Magmatic Arc with the granitogenesis of the Mineiro Belt and the Mantiqueira Complex, we suggest that there might be a continuity of this Siderian-Rhyacian-Orosirian accretionary-collisional system towards the south. The earlier and pre-collision granitogenesis of the Serrinha (Bahia-Brazil) and Congo paleoplates are younger than those of the Western Bahia Magmatic Arc and the Mineiro Belt, suggesting diachronic evolution of these tectonic systems during the formation of the Columbia Supercontinent.

\section{Acknowledgments}

The authors wish to express their acknowledgements to $\mathrm{CNPq}$ for the research fellowship grant provided to Simone Cerqueira Pereira Cruz (grant 307590/2009-7), Johildo Salomão Figueiredo Barbosa and Mauricio Antonio Carneiro. We also thank CNPq for the financial resources through the Universal Call for Projects (grant 473806/2010-0). We thank Companhia Bahiana de Pesquisa Mineral (CBPM) for the support during the field work and 
FAPEMIG for the financial support through grants CRA 00281-09, 5118-5.0207 and 2032-

05. We also thank CAPES-COFECUB (Project 624/09), which supported J. J. Peucat's and L.L. Paquette's stay at UFBA. Finally, we would like to thank the reviewers and editor of the article for their valuable contributions.

\section{References}

Alkmim, F.F., Brito Neves, B.B., Alves, J.A.C., 1993. Arcabouço tectônico do Cráton do São Francisco - uma revisão. In: Dominguez, J.M. and Misi, A. (eds) O Cráton do São Francisco. Reunião Preparatória do $2^{\circ}$ Simpósio sobre o Cráton do São Francisco. Salvador, SBG/ Núcleo BA/SE/SGM/CNPq, 45-62.

Alkmim, F.F., Martins-Neto, M.A., 2012. Proterozoic first-order sedimentary sequences ofthe São Francisco craton, eastern Brazil. Marine and Petroleum Geology 33, 127-139.

Arcanjo, J.B., Martins, A.A.M, Loureiro, H.S.C., Varela, P.H.L., 2005. Projeto Vale do Paramirim, Bahia: geologia e recursos minerais. Salvador, CBPM. Série Arquivos Abertos, $22,82 \mathrm{p}$.

Ávila, C.A., Cherman, A.F., Valença, J.G. 2008. Dioritos Brumado e Rio Grande: Geologia e relação com o metamorfismo paleoproterozóico do Cinturão Mineiro, borda meridional do Craton São Francisco, Minas Gerais. Arquivos do Museu Nacional 67, 248-277.

Ávila, C.A., Teixeira, W., Bongiolo, E.M., Dussin, I.A., Vieira, T.A.T., 2014. Rhyacian evolution of subvolcanic and metasedimentary rocks of the southern segmentof the Mineiro belt, São Francisco craton, Brazil. Precambrian Research, 243, 221-251.

Ávila, C.A., Teixeira, W., Cordani, U.G., Moura, C.A.V., Pereira, R.M., 2010. Rhyacian (2.23-2.20 Ga) juvenile accretion in the southern São Francisco craton, Brazil:geochemical and isotopic evidence from the Serrinha magmatic suite, Mineirobelt. Journal South American Earth Science, 29, 464-482.

Barbosa, J.S.F., Cruz, S.C.P., 2011. Evolução Tectônica para o Domínio Oeste e Sudoeste do Bloco Gavião, Bahia. XIII Simpósio Nacional de Estudos Tectônicos and VII International Symposium on Tectonics, Campinas, CD Room.

Barbosa, J. S. F., Sabaté, P., 2002. Geological feature and the paleoproterozoic of four archean crustal segments of the São Francisco Craton, Bahia, Brazil. A syntesis. Anais da Academica Brasileira de Ciencias, 2, 343-359. 
Barbosa, J. S. F., Sabaté, P., 2004. Archean and Paleoproterozoic crust of the São Francisco Cráton, Bahia, Brazil: geodynamic features. Precambrian Research, 133, 1-27.

Barbosa, J.S.F., Santos Pinto, M., Cruz, S.C.P., Souza, J.S. 2012. Granitoides. In: Barbosa, J.

S. F., Mascarenhas, J. F., Corrêa-Gomes, L. C., Domingues, J. M. L. (Org.). Geologia da

890

6

891

1892

1893

12

1394

1595

1896 18

1897

20

2898

2899

24

2900

26

2901

28

2902

30

3903

32

3904

34

3905

36

3906

38

3907

40

4908

42
4309

44

4910

46

4911

48

4912

50

$5 \Phi 13$

52

5814

54

$5 \overline{9} 15$

56

5916

Bahia. Pesquisa e Atualização de Dados. 1ª ed., Salvador: CBPM, 2, 327-396.

Barbosa, N.S., Teixeira, W., Bastos Leal, L. R., Leal, A B. M., 2013. Evolução crustal do setor ocidental do Bloco Arqueano Gavião, Cráton do São Francisco, com base em evidências U-Pb, Sm-Nd e Rb-Sr. Revista do Instituto de Geociências - USP, 13, 6-88.

Bastos Leal, L.R., 1998. Geocronologia U/Pb (SHRIMP), ${ }^{207} \mathrm{~Pb} /{ }^{206} \mathrm{~Pb}, \mathrm{Rb}-\mathrm{Sr}, \mathrm{Sm}-\mathrm{Nd}$ e K-Ar dos Terrenos Granito-Greenstone do Bloco do Gavião: Implicações para Evolução arqueana e proterozóica do Cráton do São Francisco, Brasil. Tese de Doutoramento, Instituto de Geociências, Universidade Estado de São Paulo, 178p.

Bastos Leal, L.R., Cunha, J.C., Cordani, U.G., Teixeira, W., Nutman, A.P., Leal, A.B.M., Macambira, M.J.B., 2003. SHRIMP U-Pb, 207Pb/206Pb zircon dating, and $\mathrm{Nd}$ isotopic signature of the Umburanas Greenstone Belt, northern São Francisco Craton, Brazil. Journal of South American Earth Sciences, 5, 775-785.

Bastos Leal, L.R., Teixeira, W., Cunha, J.C., Macambira, M.J.B., 1998. Archean tonalitictrondhjemitic and granitic plutonism in the Gavião block, São Francisco Craton, Bahia, Brazil: Geochemical and geochronology characteristics. Revista Brasileira de Geociências, 2, 209-220.

Bastos Leal, L.R., Teixeira, W., Cunha, J.C., Leal, A.B.M., Macambira, M.J.B., Rosa, M.L.S., 2000. Isotopic signatures of paleoproterozoic granitoids of the Gavião block and implications for the evolution of the São Francisco craton, Bahia, Brazil. Revista Brasileira de Geociências, 30, 66-69.

Best, M.G., 2003. Igneous and Metamorphic Petrology, second ed. Blackwell Publishing, 729 p.

Boynton, W.R., 1984. Cosmochemistry of the rare earth elements meteorite studies. In:

Henderson, P. (Ed), Rare Earth Element Geochemistry, Elsevier Science, Amsterdan, pp. 63 114.

Buhn, B., Pimentel, M.M., Matteini, M., Dantas, E.L., 2009. High spatial resolution analysis of $\mathrm{Pb}$ and $\mathrm{U}$ isotopes for geochronology by laser ablation multi-collector inductively coupled 
plasma mass spectrometry (LA-MC-ICP-MS). Anais da Academia Brasileira de Ciências, 81, $9181-16$.

Campos, L.D., 2013. O depósito de Au-Cu Lavra Velha, Chapada Diamantina Ocidental: um exemplo de depósito da classe IOCG associado aos terrenos paleoproterozoicos do Bloco Gavião. Dissertação de Mestrado, Instituto de Geociências, Universidade Federal da Bahia, 922 113p.

Conceição, H., 1986. Os granitos do Rio Caveira: Petrologia de intrusões pré-cambrianas no

cisalhamento axial do Complexo Contendas-Mirantes (Bahia-Brasil). Dissertação Mestrado, Instituto de Geociências, Universidade Federal da Bahia, 248p.

Chemale-Jr, F., Philipp, R.P., Dussin, I.A., Formoso, M.L.L., Kawashita, K., Berttotti, A.L., 2011. Lu-Hf and U-Pb age determination of Capivarita Anorthosite in the Dom Feliciano Belt, Brazil. Precambrian Research, 186, 117-126.

Cordani, U.G., Sato, K., Marinho, M.M., 1985. The geologic evolution of the ancient granitegreenstone terrane of central-southern Bahia, Brazil. Precambrian Research 27, 187-213.

Cordani, U.G., Sato, K., Teixeira, W., Tassinari, C.C.G., Basei, M.A.S., 2000. Crustal Evolution of the South American Platform. In: Cordani, U.G., Milani, E.J., Thomaz-Filho, A., Campos, D.A. (Org.). Tectonic Evolution of South America. Rio de Janeiro: 31st International Geological Congress, Rio de Janeiro, Brazil, pp. 19-40.

Cordani, U.G., Iyer, S.S., Taylor, P.N., Kawashita, K., Sato, K., Mcreath, I., 1992. Pb-Pb, Rb$\mathrm{Sr}$, and K-Ar sistematic of the Lagoa Real uranium province (south-central Bahia, Brazil) and the Espinhaço Cycle (ca. 1.5-1.0 Ga). Journal South. American Earth Science 1, 33-46.

Cruz, S.C.P., 2004. A interação tectônica entre o Aulacógeno do Paramirim e o Orógeno Araçuaí-Oeste Congo. Tese de Doutorado, Departamento de Geologia, UFOP, 505 p.

Cruz, S.C.P., Barbosa, J.S.F., Alves, E.S., Damasceno, G.C., Machado, G.S., Borges, J.O., Gomes, A.M., Mesquita, L., Pimentel, I., Leal, A.B.M., Palmeira, D.S., 2009. Mapeamento geológico e levantamentos de recursos minerais da Folha Caetité (Escala 1:100.000). Programa de Levantamentos Geológicos Básicos, Convênio UFBA-CPRM-FAPEX, Salvador, 175p.

Cruz, S.C.P., Barbosa, J.S.F., Barbosa, A.C., Jesus, S.S.G., Medeiros, E.L.M., Figueiredo, B.S., Leal, A.B.M., Lopes, P., Souza, J.S. 2014a. Mapeamento Geológico e Levantamentos de 
Recursos Minerais das Folhas Espinosa e Guanambi, escala 1:100.000. Convênio UFBA/CPRM/FAPEX, Salvador, 253p. 2 mapas.

Cruz, S.C.P., Barbosa, J.S.F., Peucat, J.J., Paquette, J.L., 2014b. Correlação estratigráfica entre as Sequencias Metavulcanossedimentares do Bloco Gavião, Bahia. In: SBG, Congresso Brasileiro de Geologia, 46, Anais, p. 1342.

Cruz, S.C.P., Peucat, J.J., Teixeira, L., Carneiro, M.A., Martins, A.A.M., Santana, J.S., Souza,

J.S., Barbosa, J.S.F., Leal, A.B.M., Dantas, E., Pimentel, M., 2012. The Caraguataí syenitic suite, a ca. 2.7 Ga-old alkaline magmatism (petrology, geochemistry and UePb zircon ages). Southern Gavião block (São Francisco Craton), Brazil. Journal of South American Earth Sciences 37: 1-18.

Cruz Filho, B. E., Martins, A.A.M. 2013. Mapa Geológico Folha Condeúba (1:100.000). Serviço Geológico do Brasil.

Cuney, M., Sabaté P. Vidal P., Marinho M.M., Conceição H., 1990. The 2 Ga peraluminous magmatism of Jacobina-Contendas-Mirante Belt (Bahia) Brazil: Major and trace element geochemistry and metallogenetic potential. Journal of Volcanology and Geothermal Energy 44: $123-141$.

Cunha, J.C., Bastos Leal, L.R., Fróes, R.J.B., Teixeira, W., Macambira, M.J.B., 1996. Idade dos greenstone belts e dos terrenos TTG's associados da região de Brumado, centro oeste do Cráton do São Francisco (Bahia-Brasil). In: SBG, Congresso Brasileiro de Geologia, 39, Anais, p. 67-70.

Cunha, J.C., Fróes, R.J.B., 1994. Komatiítos com textura spinifex do Greenstone Belt de Umburanas, Bahia. Série Arquivos Abertos, CBPM, Salvador, 29 p.

Cunha, J.C., Lopes, G.A.C., Sabaté, P., 1994. Estrutura do Bloco do Gavião no Cráton do São Francisco (Bahia, Brasil): exemplo de tectogênese diacrônica do Proterozóico Inferior a Superior de um segmento continental Arqueano. In: SBG, Congresso Brasileiro de Geologia, 38, Anais, p. 381-382.

DePaolo, D.J., 1981. A neodymium and strontium isotopic studyof the Mesozoic calc-alkaline granitic batholiths of the Sierra Nevada and Peninsular Ranges, California. J. Geophys. Res. 86, 10470-10488. 
Feybesse, J.L., Johan, V., Triboulet, C., Guerrot, C., Mayaga-Mikolo, F., Bouchot, V., Eko N'dong, J., 1998. The West Central African belt: a model of 2.5-2.0 Ga accretion and twophase orogenic evolution. Precambrian Research, 87, 161-216.

Frost, B.R., Arculus, R.J., Barnes, C.G., Collins,W.J., Ellis, D.J., Frost, C.D., 2001. A geochemical classification of granitic rocks. Journal of Petrology 42, 2033-2048.

Gioia, S.M. and Pimentel, M.M., 2000. The Sm-Nd isotopic method in the geochronology laboratory of the University of Brasília. Anais da Academia Brasileira de Ciências 2, 219-245. Guimarães, J.T., Teixeira, L.R., Silva, M.G. Martins, A.A.M., Filho, E.L.A., Loureiro, H.S.C., Arcanjo, J.B., Dalton de Souza, J., Neves, J.P., Mascarenhas, J.F., Melo, R.C., Bento, R.V., 2005. Datações U/Pb em rochas magmáticas intrusivas no Complexo Paramirim e no Rifte Espinhaço: uma contribuição ao estudo da evolução geocronológica da Chapada Diamantina. In: SBG/BA-SE, Simpósio do Cráton do São Francisco, Salvador, Anais de Resumos Expandidos, 159-161.

Harris N B W, Pearce J A, Tindle A G., 1986. Geochemical characteristics of collision- zone magmatism. In: Coward M P, Ries A C (eds) Collision Tectonics. Geological Society London Special Publication 19, pp 67-81.

Irvine, T.N. and Baragar V.R.A., 1971. A guide to the chemical classification of common volcanic rocks. Canadian Earth Science 8, 523-548.

Lameyre, J. and Bowden, P., 1982. Plutonic rock types series: discrimination of various granitoid series and related rocks. Journal of Volcanology and Geothermal Research, 14 (1982) $169-186$.

Le Maitre, R.W., 2002. Igneous Rocks. A Classification and Glossary of Terms. Recommendations of the International Union of Geological Sciences Subcom-mission on the Systematics of Igneous Rocks. Cambridge University Press, Cambridge, UK.

Le Maitre, R.W.; Batemman, P.; Dudek, A.; Keller, J.; Lameyre, J.; Le Bas, M.J.; Sabine, P.A.; Schmidt, R.; Sorensen, H.; Streckeisen, A.; Wooley, R.A.; Zannttin, B. 1989. A Classification of igneous rocks and glossary of terms: recommendation of the International Union of Geological Sciences. Subcommission on the Systematics of Igneous Rocks. Londres. Blackwell Scientific Publications, Oxford, 193p. 
Leahy, G.A.S., 1997. Caracterização Petrográfica e Litogeoquímica da Intrusão Sienítica de

Ceraíma (Sudoeste da Bahia). Dissertação de Mestrado, Instituto de Geociências, Universidade Federal da Bahia, 114p.

Leal, A.B.M, Bastos Leal, L.R., Cunha, J.C., Teixeira, W., 2005. Características geoquímicas dos granitóides transamazônicos no Bloco Gavião, Craton São Francisco, Bahia, Brasil. Geochimica Brasiliensis 19: 8-21.

Ledru, P., Johan, V., Milesi, J.P., Tegyey, M., 1994. Evidence for a 2 Ga continental accretion in the circum-south Atlantic provinces. Precambrian Research 69, 169-191.

Lopes, G.A.C., 2002. Projeto Guajeru. Salvador CBPM, V. 1, 408p.

Loureiro, H.S.C., Lima, E.S., Macedo, E.P., Silveira, F.V., Bahiense, I.C., Arcanjo, J.B.A., Moraes-Filho, J.C., Neves, J.P., Guimarães, J.T., Rodrigues, L.T., Abram, M.B., Santos, R.A., Melo, R.C., 2010. Geologia e Recursos Mineris da Parte norte do Corredor de Deformação do Paramirim: Projeto Barra-Oliveira dos Brejinhos. Salvador: CBPM, 118p. il. Série Arquivos Abertos, 33.

Ludwig, K.R., 2003. User's Manual for Isoplot/Ex version 3.00-A Geochronology Toolkit for Microsoft Excel, No. 4. Berkeley Geochronological Center Special Publication, 70 p.

Maniar, P.D., Picolli, P.M., 1989. Tectonic discrimination of granitoids. Geological Society of American Bulletin 101, 635-643.

Marinho, M.M., 1991. La séquence volcano-sédimentaire de Contendas Mirante et la bordure occidentale du Bloc de Jéquié (Craton du São Francisco, Brésil): un exemple de transition Archéan-Protérozoique. Thèse de l'Université de Clemont-Ferrand, 257p.

Marinho, M.M., Rios, D.C., Conceição, H., Rosa, M.L.S., 2008. Magmatismo alcalino neoarqueano no Cráton do São Francisco, Bahia: pluton Pé de Serra. In: SBG, Congresso Brasileiro de Geologia, 44, Anais, p. 57.

Martin, H., Moyen, J.-F., Rapp, R., 2010. Sanukitoids and the Archaean-Proterozoicboundary. Transactions of the Royal Society of Edinburgh-Earth Sciences 100,15-33.

Martins, A.A.M. 2014. Projeto Brumado - Condeúba. Salvador: CPRM, 2014. No prelo. Programa Geologia do Brasil - PGB.

Martin, H., Peucat, J.J., Sabaté, P., Cunha, J.C., 1991. Um segment de croûte continentale d'Age archéean ancien (3.5 millards d'années): lê massif de Sete Voltas (Bahia, Brésil). Les Comptes Rendus de l'Académie des Sciences Paris 313, 531-538. 
Martin, H., Moyen, J.-F., Rapp, R., 2010. Sanukitoids and the Archaean-Proterozoicboundary.

Transactions of the Royal Society of Edinburgh-Earth Sciences 100,15-33.

Martins, A.A.M. 2014. Projeto Brumado - Condeúba. Salvador: CPRM, 2014. No prelo. Programa Geologia do Brasil - PGB.

Mascarenhas, J.F., 1979. Evolução Geotectônica do Precambriano do Estado da Bahia. In: Inda, H. A. V. (Ed.), Geologia e Recursos Minerais do Estado da Bahia. Textos Básicos. SME/CPM, Salvador, Bahia, 2, 57-165.

Medeiros, E. L., 2013. Geologia e geocronologia do complexo Santa Izabel na região de Urandi, Bahia. Universidade Federal da Bahia. Dissertação de Mestrado, 203p.

Medeiros, L.M., Cruz, S.C.P., Barbosa, J.S.F., Carneiro, M.A., Jesus, S.S.G.P., Armstrong, R., Brito, R., Delgado, I., 2011. Ortognaisses migmatíticos do Complexo Santa Isabel na região de Urandi-Guanambi, Bahia: análise estrutural, geocronologia e implicações tectônicas. In: SBG, XIII Simpósio Nacional de Estudos Tectônicos and VII International Symposium on Tectonics, Campinas, CD de resumos expandidos.

Muller, D., and Groves, D.I., 1993. Direct and indirect associations between potassic igneous rocks, shoshonites and gold-copper deposits: Ore Geology Reviews, v. 8, p. 383- 406.

Noce, C.M., Pedrosa Soares, A.C., Silva, L.C., Armstrong, R., Piuzana, D., 2007. Evolution of polycyclic basement complexes in the Aracuaí Orogen, based on U-Pb SHRIMP data: Implications for Brazil-Africa links in Paleoproterozoic time. Precambrian Research 159, 6078.

Noce, C.M., Teixeira, W., Quemeneur, J.J.G., Martins, V.T.S., Bolzachini, E., 2000. Isotopic signatures of Paleoproterozoic granitoids from the southern São Francisco Craton and implications for the evolution of the Transamazonian Orogeny. Journal of South American Earth Sciences, $13: 225-239$.

Nunes, L.C., 2007. Geocronologia, Geoquímica Isotópica e Litoquímica do Plutonismo Diorítico-Granítico entre Lavras e Conselheiro Lafaiete: Implicações para a Evolução Paleoproterozóica da Parte Central do Cinturão Mineiro. Dissertação de Mestrado, Instituto de Geociências, Universidade de São Paulo, 218p 
Nutman, A.P. and Cordani, U.G., 1993. SHRIMP U-Pb zircon geochronology of Archean granitoids from the Contendas Mirante area of the São Francisco Craton, Bahia, Brazil. Journal of South American Earth Science 7, 107-114.

Paim, M.M., 1998. Petrologia da Intrusão Sienítica de Cara Suja (Sudoeste da Bahia). Dissertação de Mestrado, Instituto de Geociências, Universidade Federal da Bahia, 147p.

Paim, M.M., 2014. Maciço De Cara Suja: Expressão do Magmatismo Alcalino Potássico PósColisional No Sudoeste da Bahia. Tese de Doutorado, Instituto de Geociências, Universidade Federal da Bahia, 188p.

Palmeiras, D.S., 2010. Petrografia do granitoide Broco: evidência de fusão crustal no greenstone belt ibitira-ubiraçaba, ibiassucê, bahia. Trabalho Final de Graduação, Universidade Federal da Bahia, 78 p.

Pearce, J.A., 1996. Sources and settings of granitic rocks. Episodes 19, 120-125.

Pearce, J.A., Harris, N.B.W., Tindle, A.G., 1984. Trace Element Discrimination Diagrams for the Tectonic Interpretation of Granitic Rocks. Journal of Petrology, 25, 956-983.

Pedrosa Soares, A.C.P., Noce, C.M., Vidal, P.H., Monteiro, R.L.B.P., Leonardos, C.O. H., 1992. Toward a new model for the Late Proterozoic Araçuaí (SE Brazil) - West Congolian (SW Africa) Belt. Journal South American Earth Science, 1/2, 22-47.

Pedrosa Soares, A.C.; Noce, C.M.; Wiedemann, C.M., Pinto, C.P., 2001. The Araçuaí-WestCongo Orogen in Brazil: An overview of a confined orogen formed during Gondwanaland assembly. Precambrian Research, 110, 307-323.

Petta, R.A., 1979. Geoquímica do granito Gameleira e suas relações com o embasamento da Bacia do Médio Rio de Contas, Bahia. Dissertação de Mestrado, Instituto de Geociências, Universidade Federal da Bahia, 147p.

Peucat, J.J., Barbosa, J.S.F., Pinho, I.C. A., Paquette, J.L., Martin, H., Fanning, C.M., Leal, A.B.M., Cruz, S., 2011. Geochronology of granulites from the south Itabuna-Salvador-Curaçá Block, São Francisco Craton (Brazil): Nd isotopes and U-Pb zircon ages. Journal of South American Earth Sciences 31: 397-413.

Peucat, J.J., Mascarenhas, J.F., Barbosa, J.S.F., de Souza, S.L., Marinho, M.M., Fanning, C.M., Leite, C.M.M., 2002. 3.3 Ga SHRIMP U-Pb zircon age of a felsic metavolcanic rock 
from the Mundo Novo Greenstone belt in the São Francisco Craton, Bahia (NE Brazil). South

American Journal of Earth Sciences 15, 363-373.

Plank, T., Langmuir, C.H., 1998. The chemical composition of subducting sedimentand its consequences for the crust and mantle. Chemical Geology, 145, 325-394.

Porada, H., 1989. Pan-African rifting and orogenesis in southern to equatorial Africa and Eastern Brazil. Precambrian Research, 44, 103-136.

Pupin, J. P., 1980. Zircon and granite petrology. Contribution to Mineralogy and Petrology 73, 207-220.

Rapp, R.P., Norman, M.D., Laporte, D., Yaxley, G.M., Martin, H., Foley, S.F., 2010. Continent formation in the Archean and chemical evolution of the cratonic litho-sphere: meltrock reaction experiments at 3-4 GPa and petrogenesis of ArcheanMg-diorites (sanukitoids). Journal of Petrology, 51, 1237-1260.

Rios, D.C., Davis, D.W., Conceicão, H. Davis, W.J., Rosa, M.L.S., Dickin, A.P., 2009. Geologic evolution of the Serrinha nucleus granite-greenstone terrane (NE Bahia, Brazil) constrained by U-Pb single zircon geochronology. Precambrian Research 170: 175-201.

Rios, D.C., Davis, D.W., Conceicão, H., Rosa, M.L.S., Davis, W.J., Dickin, A.P., Marinho, M.M., Stern, R., 2008. 3.65-2.10 Ga history of crust formation from zircon geochronology and isotope geochemistry of the Quijingue and Euclides plutons, Serrinha nucleus, Brazil. Precambrian Research 167, 53-70.

Rodrigues, J. B., Guimarães, J. T., Borges, V. P., Carvalho, C. B., Nogueira, A. C., 2012. Ryacian zircon age of metabasaltic rocks from Riacho de Santana Greenstone Belt, Bahia (Brazil). VIII South American Symposium on Isotope Geology. Medellin. CD-ROM.

Rosa, M.L.S., 1999. Geologia, geocronologia, mineralogia, litogeoquímica e petrologia do Batólito Monzo-Sienítico Guanambi-Urandi (SW-Bahia). Tese de Doutorado - Instituto de Geociências, Universidade Federal da Bahia, Salvador. 186p.

Rosa, A.M.L.S., Conceição, H., Oberli, F., Meier, M., Martin, H., Macambira, M.B., Santos, E.B., Paim, M.M., Leahy, G.A.S., Bastos Leal, L.R., 2000. Geochronology (U-Pb/Pb-Pb) and isotopic signature $(\mathrm{Rb}-\mathrm{Sr} / \mathrm{Sm}-\mathrm{Nd})$ of the paleoproterozoic Guanambi Batholith, southWestern Bahia State (NE Brazil). Revista Brasileira de Geociências 30: 062-065.

Rosa, A.M.L.S., Conceição, H, Paim, M.M., Santos, E.B., Alves, F.C. Leahy, G.S., Leal, L.R., 1996. Magmatismo potássico/ultrapotássico pós a tardi orogênico associado à 
subducção no oeste da Bahia: Batólito Monso-sienitico de Guanambi-Urandi e os sienitos de

Correntina. Geochimica Brasiliensis 1, 027-042.

Sabaté, P., Marinho, M.M., Vidal, P., Vauchette, M., 1990. The 2-Ga peraluminous magmatism of the Jacobina-Contendas Mirantes Belts (Bahia, Brazil): Geologic and isotopic constraints on the sources. Chemical Geology 83, 325-338.

Santos, E.B., 1999. Petrologia dos Sienitos e Monzonítos Potássicos do Maciço do Estreito (SW-Bahia e NE-Minas Gerais.. Dissertação de Mestrado, Instituto de Geociências, Universidade Federal da Bahia, p.140.

Santos, E. B., 2005. Magmatismo Alcalino Potássico Paleoproterozoico no Sudoeste da Bahia e Nordeste de Minas Gerais: Evidência de Plutonismo Orogênico Associado a Arco Continental. Tese de Doutoramento, CPG Geologia, IGEO/UFBA, 163p.

Santos Pinto, M., Peucat, J.J., Martin, H., Sabaté, P., 1998. Recycling of the Archaean continental crust: the case study of the Gavião Block, Bahia, Brazil. Journal of South American Earth Science 11, 487-498.

Santos Pinto, M.A., 1996. Le recyclage de la croúte continentale archéenne: Exemple du bloc du Gavião-Bahia, Brésil. Mémoire de Géociences Rennes 75, 193p.

Santos Pinto, M., Peucat, J.J., Martin, Barbosa, J.S.F., Mark Fanning, C.M., Cocherie, A., Paquette, J.L., 2012. Crustal evolution between 2.0 and $3.5 \mathrm{Ga}$ in the southern Gavião block (Umburanas-Brumado-Aracatu region), São Francisco Craton, Brazil: A 3.5e3.8 Ga protocrust in the Gavião block?. Journal of South American Earth Science 40, 129-142.

Sawyer, E.W., 2008. Atlas of Migmatites, The Canadian Mineralogist, pp. 371.

Seixas, L.A.R., Bardintzeff, J.-M., Stevenson, R., Bonin, B., 2013. Petrology of the high-Mg tonalites and dioritic enclaves of the ca. 2130 Ma Alto Maranhão suite: evidence for a juvenile crustal addition event during the Rhyacian oroge-nesis, Mineiro Belt, southeast Brazil. Precambrian Research, 238, 18-41.

Seixas, L.A.R., David, J., Stevenson, R., 2012. Geochemistry, Nd isotopes and U-Pb geochronology of a 2350 Ma TTG suite, Minas Gerais Brazil: implications for the crustal evolution of the southern São Francisco craton. Precambrian Research 196-197, 61-80.

Silva, L.C, Pedrosa Soares, A.C., Teixeira, L. R., Armstrong, R., 2008. Tonian rift-related, Atype continental plutonism in the Araçuaí Orogen, eastern Brazil: New evidence for the 
breakup stage of the São Francisco-Congo Paleocontinent. Gondwana Research , 13, 527 537.

Silva, L.C., McNaughton, N.J., Melo, R.C., Fletcher, J.R., 1997. U-Pb SHRIMP ages in the Itabuna-Caraíba TTG high-grade Complex: the first window beyond the Paleoproterozoic overprinting of the eastern Jequié craton, NE Brazil. In: International Symposium on Granites and Associated Mineralizations, 2, Salvador. Extended Abstract and Program, 282-283.

Silva, L.C da, Armstrong, R., Delgado, I.M., Pimentel, M., Arcanjo, J.B., Mello, R.C., JostEvangelista, H., Cardoso Filho, J.M., Pereira, L.H.M., 2002a. Reavaliação da evolução geológica em terrenos pré-cambrianos brasileiros com base em novos dados U-Pb SHRIMP, Parte I: Limite centro-oriental do Cráton São Francisco na Bahia. Revista Brasileira de Geociências, 32(2), 501-512.

Silva, L.C., Armstrong, R., Noce, C.M., Carneiro, M.A., Pimentel, M., Pedrosa Soares, A. C., Leite, C.A., Vieira, V.S., Silva, M.A., Paes, V.J.C., Cardoso-Filho, J.M., 2002b. Reavaliação da evolução geológica em terrenos pré- cambrianos brasileiros com base em novos dados UPB SHRIMP, Parte 2: Orógeno Araçuaí, Cinturão mineiro e Cráton São Francisco Meridional. Revista Brasileira de Geociências 32, 513-528.

Souza, J.D., Kosin, M., Melo, R.C., Teixeira, L.R., Sampaio, A.R., Vieira Bento, R., Borges, V.P., Martins, A.A.M., Arcanjo, J.B., Loureiro, H.S.C., Angelim, L.A.A., 2003. Mapa Geológico do Estado da Bahia - Escala 1:1.000.000. Salvador, CPRM, Versão 1.1, Programas Carta Geológica do Brasil ao Milionésimo e Levantamentos Geológicos Básicos do Brasil (PLGB). Convênio de Cooperação e Apoio Técnico-Científico CBPM-CPRM.

Streckeisen, A.L., 1967. Classification and nomenclature of igneous rocks. Neues Jahrb.Mineral. Abh., 107 (2/3): 144--240.

Teixeira, L.R., 2000. Projeto Vale do Paramirim. Relatório Temático de Litogeoquímica. Convênio CPRM/CBPM, 35p.

Teixeira, L., 2005. Projeto Ibitiara-Rio de Contas. Relatório Temático de Litogeoquímica. Convênio CPRM/CBPM, 33p.

Teixeira, L., 2014. Projeto Brumado-Condeúba. Relatório Temático de Litogeoquímica. Convênio CPRM/CBPM, 84p. 
Teixeira, W., Ávila, C.A., Dussin, I.A., Corrêa Neto, A.V., Bongiolo, E.M., Santos, J.O., Barbosa, N.S., 2015. A juvenile accretion episode (2.35-2.32 Ga) in the Mineiro belt andits role to the Minas accretionary orogeny: Zircon $\mathrm{U}-\mathrm{Pb}-\mathrm{Hf}$ andgeochemical evidences. Precambrian Research, 256, 148-169.

Thieblemont, D., Castaing, C., Billa, M., Bouton, P., Preat, A., 2009. Notice explicative de la Carte géologique et ades Ressources minerals de la Republique Gabonaise à 1/1.000.000. Editions DGMG- Minstère des Mines, du Pétrole, des Hydrocarbures, Libreville, 384p.

Trompette, R., 1994. Geology of Western Gondwana (2000-500 Ma). Balkema, Amsterdam. $350 \mathrm{pp}$.

Vitória, R.S., 2014. Estudos petrográfico e geoquímico das rochas máficas do Greenstone Belt Ibitira-Ubiraçaba, Folha Caetité, BA. Trabalho Final de Graduação, Universidade Federal da Bahia, $110 \mathrm{p}$.

Zincone, T. and Oliveira, E. P., 2014. A Sequência supracrustal Contendas-Mirante, norte do Craton São Francisco: evidências de uma Bacia Foreland Paleoproterozoica. In: SBG, Congresso Brasileiro de Geologia, 46, Anais, p. 1342.

Wosniak, R., A.A.M.M, Oliveira, R.L.M., 2013. Mapa Geológico Folha Condeúba (1:100.000). Serviço Geológico do Brasil.

\section{Figures captions}

Figure 1. Schematic geological map showing the limits, marginal fold belts and major structural units of the São Francisco Craton. Adapted from Alkmin et al. (1993). The grey rectangle indicates the study area.

Figure 2. Location of the Gavião Paleoplate granitoids. Adapted from Barbosa et al. (2012).

Figure 3. Field aspects of the studied granitoids. (a) Jussiape II granite, (b) Lagoa das Almas granodiorite, (c) Humaitá granodiorite, (d) Belo Campo granodiorite (e) Broco granodiorite. Figure 4. QAP modal diagram (after Strekeisen, 1967) for the Jussiape II, Lagoa das Almas, Humaitá, Belo Campo and Broco granitoids showing important fields of various granitoid series of the Lameyre and Bowden (1982).

Figure 5. Zircon U-Pb concordia plot for the Jussiape II granite (Sample SCP SJ 01) (a, b) and Lagoa das Almas granite (Sample L-05) (c). TL = transmitted light and BS = backscattered images. White circles correspond to the laser spot (size $\sim 20 \mu \mathrm{m}$ ). Ellipses are reported at $1 \sigma$. 
Figure 6. Zircon U-Pb concordia plot for the Humaitá granodiorite (Sample OPU-6356) (a, b) and Belo Campo granite-gneiss $(\mathrm{c}, \mathrm{d}) . \mathrm{TL}=$ transmitted light and $\mathrm{BS}=$ backscattered images. White circles correspond to the laser spot (size $\sim 20 \mu \mathrm{m}$ ). Ellipses are reported at $1 \sigma$. Zircon (e) and monazite (f) U-Pb concordia plot for the Broco granitoid (Sample TB-05). TL = transmitted light and BS = backscattered images. White circles correspond to the laser spot (size $\sim 20 \mu \mathrm{m}$ ). Ellipses are reported at $1 \sigma$.

Figure 7. Epsilon Nd vs time diagram for the samples of the Jussiape II, Humaitá, Belo Campo and Broco granitoids. Field for the Archean gneisses of the Gavião Block, after Santos-Pinto et al. (2012) and Barbosa et al. (2013), as well as the granitoids of the Gavião Block (consult references in table 1), are reported. * = Granitoids studies herein.

Figure 8. Harker-like diagrams of major (wt.\%) and trace elements (ppm) for Jussiape II, Lagoa das Almas, Humaitá, Belo Campo and Broco granitoids.

Figure 9. Whole-rock, major and trace element geochemistry for Humaitá, Lagoa das Almas, Jussiape II and Broco granitoids. (a) $\mathrm{FeOt} /\left(\mathrm{FeOt}+\mathrm{MgO}\right.$ ) ( $\mathrm{Fe}$-index) versus $\mathrm{SiO}_{2}$ diagram (Frost et al., 2001). (b) $\mathrm{Na}_{2} \mathrm{O}+\mathrm{K} 2 \mathrm{O}-\mathrm{CaO}$ (MALI) versus $\mathrm{SiO}_{2}$ plot. (c) Diagram $[\mathrm{Al} 2 \mathrm{O} 3 /(\mathrm{CaO}+\mathrm{Na} 2 \mathrm{O}+\mathrm{K} 2 \mathrm{O})]_{\mathrm{mol}}$ versus $[\mathrm{Al} 2 \mathrm{O} 3 /(\mathrm{Na} 2 \mathrm{O}+\mathrm{K} 2 \mathrm{O})]_{\mathrm{mol}}$ (Maniar and Picolli, 1989). (d, e) Tectonic discrimination diagrams according to Pearce (1996). WPG- Within plate granites, ORG- Ocean Ridge granites, VAG- Volcanic Arc granites, Syn-COLG- Syncollision granites and Pos-COLG- Post-collision granites.

Figure 10. (a-d) REE patterns for the studied granitoids normalized to chondrite values after Boynton (1984); (e-h) Spider diagrams normalized to ORG (ocean ridge Granites) values after Pearce et al. (1984).

Figure 11. Crystallization ages for the granitoids of the southern region of the Gavião Paleoplate. Based on table 1.

Figure 12. QAP modal diagram (after Streekeisen, 1967) for the granitoids of the southern region of the Gavião Paleoplate showing important fields of various granitoid series by Lameyre and Bowden (1982). Data for the granitoids: Aracatu (Santos Pinto 1996), Boquira (Arcanjo et al., 2005), Broco (this work), Caculé (Bastos Leal 1998, Cruz et al., 2009), Campo do Meio (Lopes 2002), Cara Suja (Rosa 1999, Paim 1998, 2014), Ceraíma (Rosa 1999, Santos 1999, 2005), Espírito Santo (Bastos Leal 1998, Cruz et al., 2009), Estreito (Rosa 1999, Leahy 1997), Guanambi (Rosa 1999), Humaitá (this study), Ibitirara (Guimarães et al., 2005), Iguatemi (Bastos Leal 1998), Jussiape I (Guimarães et al., 2005), Jussiape II (this study), Lagoa das Almas (this study), Mariana (Santos Pinto 1996), Pé do Morro and Piripá 
(Cruz Filho and Martins 2013), Ibitiara-Queimada Nova (Arcanjo et al., 2005), Rio do Paulo

(Bastos Leal 1998), Santa Isabel (Cruz et al., 2014b), Serra da Franga (Santos Pinto 1996), Umburanas (Santos Pinto 1996, Martins et al., 2014), Veredinha (Arcanjo et al., 2005).

Figure 13. (a-1) Harker-like diagrams of major elements (wt.\%) for the granitoids of the southern region of the Gavião Paleoplate; (m) $\mathrm{K}_{2} \mathrm{O}$ versus $\mathrm{Ba}$; (n) $\mathrm{Sr}$ versus $\mathrm{CaO}$ for the groups of granitoids individualized in this article.

Figure 14. Harker-like diagrams of trace elements (ppm) for the granitoids of the southern

1355 14 1856 region of the Gavião Paleoplate.

Figure 15. (a) Figure 15- discriminative diagrams for the samples of the individualized groups of granitoids in the present study. (a) $\mathrm{K}_{2} \mathrm{O}$ versus $\mathrm{Na}_{2} \mathrm{O}$ with the limit (full line) that separates the potassic and sodic rocks according to Le Maitre et al. (1989). The dashed lines represent the fields with proportions between $\mathrm{K}_{2} \mathrm{O}$ and $\mathrm{Na}_{2} \mathrm{O}$; (b) $\mathrm{K}_{2} \mathrm{O}-\mathrm{Na}_{2} \mathrm{O}$ diagram, alkaline and subalkaline fields from Irvine and Baragar, (1971); (c) $\mathrm{K}_{2} \mathrm{O}-\mathrm{SiO}_{2}$ diagram, high-, mediumand low-K series fields from Le Maitre (2002); (d) $\mathrm{FeO}_{\mathrm{t}} /\left(\mathrm{FeO}_{\mathrm{t}}+\mathrm{MgO}\right)$ versus $\mathrm{SiO}_{2}$ diagram (Frost et al., 2001); (e) $\mathrm{Na}_{2} \mathrm{O}+\mathrm{K}_{2} \mathrm{O}-\mathrm{CaO}$ (MALI) versus $\mathrm{SiO}_{2}$ plot (Frost et al., 2001).

Figure 16. (a-e) REE patterns for the studied granitoids normalized to chondrite values after Boynton (1984). The yellow polygon shows the values for the Alto do Maranhão granitoid (see text for discussion); (e) and (f) total REE versus ( $\mathrm{La} / \mathrm{Yb}) \mathrm{N}$ and $\mathrm{Eu} / \mathrm{Eu}^{*}$ ratios, respectively.

Figure 17. a-e) Spider diagrams normalized to ORG (Ocean Ridge Granites) values after Pearce et al. (1984) for the groups of granitoids individualized in this study. f) Spider diagrams normalized to ORG for some granitoids presented by Pearce et al., (1984).

Figure 18- Tectonic discrimination diagrams according to (a) Harris et al. (1986), (b, c) Pearce et al. (1984), and (d-f) Müller and Groves (1993). WPG- Within plate granites, ORGOcean Ridge granites, VAG- Volcanic Arc granites, Syn-COLG- Syn-collision granites and Pos-COLG- Post-collision granites.

Figure 19. Comparison of the $\square_{\mathrm{Nd}}(\mathrm{t})$ data for the various granitoids of the southern region of the Gavião Paleoplate. See text for discussion.

Figure 20. Schematic model of the tectonic environment for the formation of the granitoids of groups 1 and 2. a) 2.38 to 2.1: installation of a magmatic arc and a subduction zone to the west, producing the calcic to calc-alkalic granitic group 1; b) metamorphism between 2.1 and $2.09 \mathrm{Ga}$ with syn-collisional migmatization; c) 2.06 to 2.04 : crystallization of alkali to alkali calcic granitoids of Group 2a and of alkali - calcic to alkali granitoids of Group 2b; (d) 2.04 
1280

to 1.8: large anatexis associated with the melting of continental crust and metavolcanosedimentary rocks and crystallization of the granitoids of groups $2 \mathrm{c}$ and $2 \mathrm{~d}$. Figure 21. Summary of the age of pre-collisional and post-collisional granitoids in the Gavião Paleoplate (Ar- Aracatu, H- Humaitá, I- Ibitiara, JI- Jussiape I, LA- Lagoa das Almas, RPRio do Paulo, V- Veredinha), Mineiro Belt (AM- Alto Maranhão, Br- Brumado, CaCassiterita, G- Glória, Ge- Gentil, LD- Lagoa Doutorada, La- Lajedo, R- Ritápolis, SSerrinha and Ti- Tiradentes), Mantiqueira Belt (D- Several granitoids from Noce et al. (2007), EC- Ewbank da Câmara, Pn1- Ponte Nova 1/inherited nuclei, Pn2- Ponte Nova 2, PRG-Piedade do Rio Grande, RPo-Rio Pomba), Serrinha Paleoplate (A-Arara, B-Barrocas, Ca- Cansação, C- Cipó, Ef- Eficeas, Eu- Euclides, It-Itareru, L- Lagoa dos Bois, NNordestina, Q- Quinjingue, Te-Teofilanfia, T-trilhado) and eburnean granitoids of the Congo Paleoplate (LW- Lambaréné-Waka, O- L’Ogooué). Based on Silva et al. (2002b), Nunes (2007), Rios et al. (2008, 2009 and authors cited therein), Noce et al. (2007), Thieblemont et al. (2009 and authors cited therein) and the authors cited in table 1.

Figure 22. Suggested outline for the continuity between the Western Bahia Magmatic Arc and the Mantiqueira and Mineiro arcs. GP- Gavião Paleoplate, JP- Jequié Paleoplate, SP- Serrinha Paleoplate.

Figure 23. Comparison between the $\square_{\square d}(\mathrm{t})$ data of the various granitoids in the southern region of the Gavião Paleoplate and the $\square_{\square d}(\mathrm{t})$ data of the granitoids of the Mineiro Belt, of the Archean Basement of the São Francisco Craton and the Lavras mafic dike swarm of the Mineiro Belt. Groups A and B were obtained from Noce et al. (2000). See text for discussion.

\section{Table captions}

Table 1. Summary of the U-Pb ages (SHRIMP, TIMS and LA-ICPMS) in the Gavião Paleoplate and the corresponding Nd isotopes modified from Santos Pinto et al., (2012). Methodologies: (i) U-Pb: (1) SHRIMP, (2) TIMS evaporation, (3) TIMS (ID), (4) LA ICPMS, (5) EPMA.(ii) (6) Rb-Sr. References: (1) Sabaté et al (1990) (2) Santos Pinto (1996), (3) Santos Pinto et al. (1998), (4) Rosa (1999), (5) Bastos Leal et al. (2000), (6) Rosa et al. (2000), (7) Lopes (2002), (8) Arcanjo et al. (2005), (9) Guimarães et al. (2005), (10) Santos Pinto et al. (2012), (11) Campos (2013), (12) Medeiros (2013), (13) Cruz Filho and Martins (2013), Wosniak et al. (2013).

Table 2. Summary of the LA-ICPMS U-Pb zircon results. Uncertainties are given at a $1 \sigma$ level. (-) parameter not analyzed. Coordinates in UTM (WGS 84 Datum). 
Table 3. Whole rock Sm-Nd results for the rock studied.

Table 4. Whole rock chemical analysis for the Jussiape II granitoid. Oxides are in wt.\% and trace elements in ppm. Detection limit for major elements was $0.01 \%$ and for trace elements: $\mathrm{Rb}(>2 \mathrm{ppm}), \mathrm{Sr}$ (> $10 \mathrm{ppm}), \mathrm{Ba}(>10 \mathrm{ppm}), \mathrm{Ga}(>0.1 \mathrm{ppm}), \mathrm{Cs}(>0.05 \mathrm{ppm}), \mathrm{Nb}(>0.05$ ppm), Y (> $10 \mathrm{ppm}), \mathrm{Zr}(>10 \mathrm{ppm}), \mathrm{Hf}(>0.05 \mathrm{ppm}), \mathrm{Ta}(>0.05 \mathrm{ppm}), \mathrm{Th}(>0.1 \mathrm{ppm}), \mathrm{U}(>$ $0.05 \mathrm{ppm}), \mathrm{La}(>0.1 \mathrm{ppm}), \mathrm{Ce}(>0.1 \mathrm{ppm}), \mathrm{Nd}(>0.1 \mathrm{ppm}), \mathrm{Sm}(>0.1 \mathrm{ppm}), \mathrm{Eu}(>0.05$ ppm), Gd (>0.05 ppm), Tb (>0.05 ppm), Dy (>0.05 ppm), Ho (>0.05 ppm), Er (>0.05 ppm), Yb (>0.1 ppm), Lu (>0.05).

Table 5. Whole rock chemical analysis for the Lagoa das Almas granitoid. Oxides are in wt.\% and trace elements in ppm. 1.The detection limit for major and trace elements is the same of table 4 .

Table 6. Whole rock chemical analysis for the Humaitá granitoid. Oxides are in wt.\% and trace elements in ppm. The detection limit for major and trace elements is the same of table 4.

Table 7. Whole rock chemical analysis for the Broco granitoid. Oxides are in wt.\% and trace elements in ppm. The detection limit for major and trace elements is the same of table 4.

Table 8. Synthesis of the geochemical data for the granitoids of the southern Gavião Paleoplate elaborated from Appendix 1.

\section{Appendix captions}

Appendix 1- Geochemical data (Major elements) for the granitoids of the southern Gavião Paleoplate: Aracatu (Santos Pinto 1996), Boquira (Teixeira 2000), Broco (this study), Caculé (Bastos Leal 1998, Leal et al., 2005), Caetano-Aliança (Cuney et al., 1990), Campo do Meio (Lopes 2002), Cara Suja (Rosa 1999, Paim 1998, 2014), Ceraíma (Rosa 1999), Espírito Santo (Bastos Leal 1998, Leal et al., 2005), Estreito (Rosa 1999, Santos 2005), Gameleira granitoid (Petta 1979, Marinho 1991, Cuney et al., 1990), Guanambi-Urandi multiples intrusion (Rosa 1999), Humaitá (this study), Ibitirara-Queimada Nova (Teixeira 2005), Iguatemi-Pé do Morro (Bastos Leal 1998, Leal et al., 2005, Teixeira 2014), Jussiape I (Teixeira 2005), Jussiape II (this study), Lagoa das Almas (this study), Lagoa Grande-Lagoinha (Conceição 1986, Cuney et al., 1990), Mariana (Santos Pinto 1996), Piripá (Teixeira 2014), Riacho das Pedras (Cuney et al., 1990, Marinho 1991), Rio do Paulo (Bastos Leal 1998, Leal et al., 2005, Teixeira 2014), Santa Isabel (Cruz et al., 2014b), Serra da Franga (Santos Pinto 1996), Umburanas (Santos Pinto 1996, Teixeira 2014), Veredinha (Teixeira 2000) granitoids. NC- Normative corundum. 
1346 Appendix 2- Geochemical data (Trace elements) for the granitoids of the southern Gavião

1347 Paleoplate. 2. The data source is the same of Appendix 1.

1348 Appendix 3- Geochemical data (Trace elements) for the granitoids of the southern Gavião 1349 Paleoplate. The data source is the same of Appendix 1.

1350 Appendix 4- Geochemical data for the granitoids of the southern Gavião Paleoplate based on 1351 the data from appendices 1 through 3 .

9

10

11

12

13

14

15

16

17

18

19

20

21

22

23

24

25

26

27

28

29

30

31

32

33

34

35

36

37

38

39

40

41

42

43

44

45

46

47

48

49

50

51

52

53

54

55

56

57

58

59

60

61 
Table 1.

\begin{tabular}{|c|c|c|c|c|c|c|c|c|c|c|}
\hline Group & Granitoid & Sample & Rock type & $\begin{array}{c}\text { Zircon age } \\
\text { (Ma or Ga) } \\
\pm 2 \delta \\
\text { (inherited) }\end{array}$ & Method & $\begin{array}{c}\text { Monazite* } \\
\text { age }\end{array}$ & $\begin{array}{c}\text { Methodolog } \\
\mathbf{y}\end{array}$ & $\begin{array}{c}\text { Nd } \\
\text { TDM } \\
\text { in Ga }\end{array}$ & $\begin{array}{c}\varepsilon(\mathbf{t}) \text { with } \\
t= \\
\text { zircon } \\
\text { age }\end{array}$ & Reference \\
\hline 1 & Aracatu & ARA170 & Isotropic granite & $\begin{array}{c}1999 \pm 14 \text { to } \\
2262 \pm 22\end{array}$ & 2 & $x y$ & & 3.58 & $-12,19$ & 2,3 \\
\hline 1 & Aracatu & ARA81-4 & $\begin{array}{c}\text { Leucossome of an } \\
\text { Archean } \\
\text { trondhlemite }\end{array}$ & $\begin{array}{c}2.38 \text { (to } 2.93 \\
\text { Ga) }\end{array}$ & 2 & & & 3.77 & $-12,95$ & 2,3 \\
\hline 1 & Humaitá & & Granodiorite & $2140 \pm 9$ & 4 & & & 2.76 & -4.0 & This work \\
\hline 1 & Ibitiara & & Tonalite & $2.091 \pm 6.6$ & 4 & & & & & 9 \\
\hline 1 & Ibitiara & IBI-01 & Granodiorite & $2.174+17-15$ & 4 & & & & & 11 \\
\hline 1 & Ibitiara & FPP-05 & Granodiorite & $2.174 \pm 51$ & & & & & & 11 \\
\hline 1 & $\begin{array}{l}\text { Lagoa das } \\
\text { Almas }\end{array}$ & L-05 & Granodiorite & $\begin{array}{c}2114 \pm 24 \\
(2250 \pm 23 \\
\mathrm{Ma})\end{array}$ & 4 & & & & & This work \\
\hline 1 & $\begin{array}{c}\text { Rio do } \\
\text { Paulo }\end{array}$ & & Granite & $2324 \pm 6$ & 4 & & & & & 13 \\
\hline 1 & Veredinha & & $\begin{array}{l}\text { Monzogranite and } \\
\text { granodiorite }\end{array}$ & $2113 \pm 11$ & 4 & & & & & 8 \\
\hline 1 & Jussiape I & & Granite & $2121 \pm 2.2$ & 4 & & & & & 9 \\
\hline $2 a$ & Boquira & & $\begin{array}{c}\text { Biotite } \\
\text { monzogranite }\end{array}$ & $2041 \pm 23$ & 4 & & & & & 8 \\
\hline $2 a$ & Cara Suja & 974 & Syenite & $2053 \pm 3$ & 3 & & & 2.61 & -7.5 & 4 \\
\hline $2 \mathrm{a}$ & Ceraíma & 1188 & Syenite & $2050 \pm 1$ & 3 & & & 2.84 & -9.5 & 4 \\
\hline
\end{tabular}




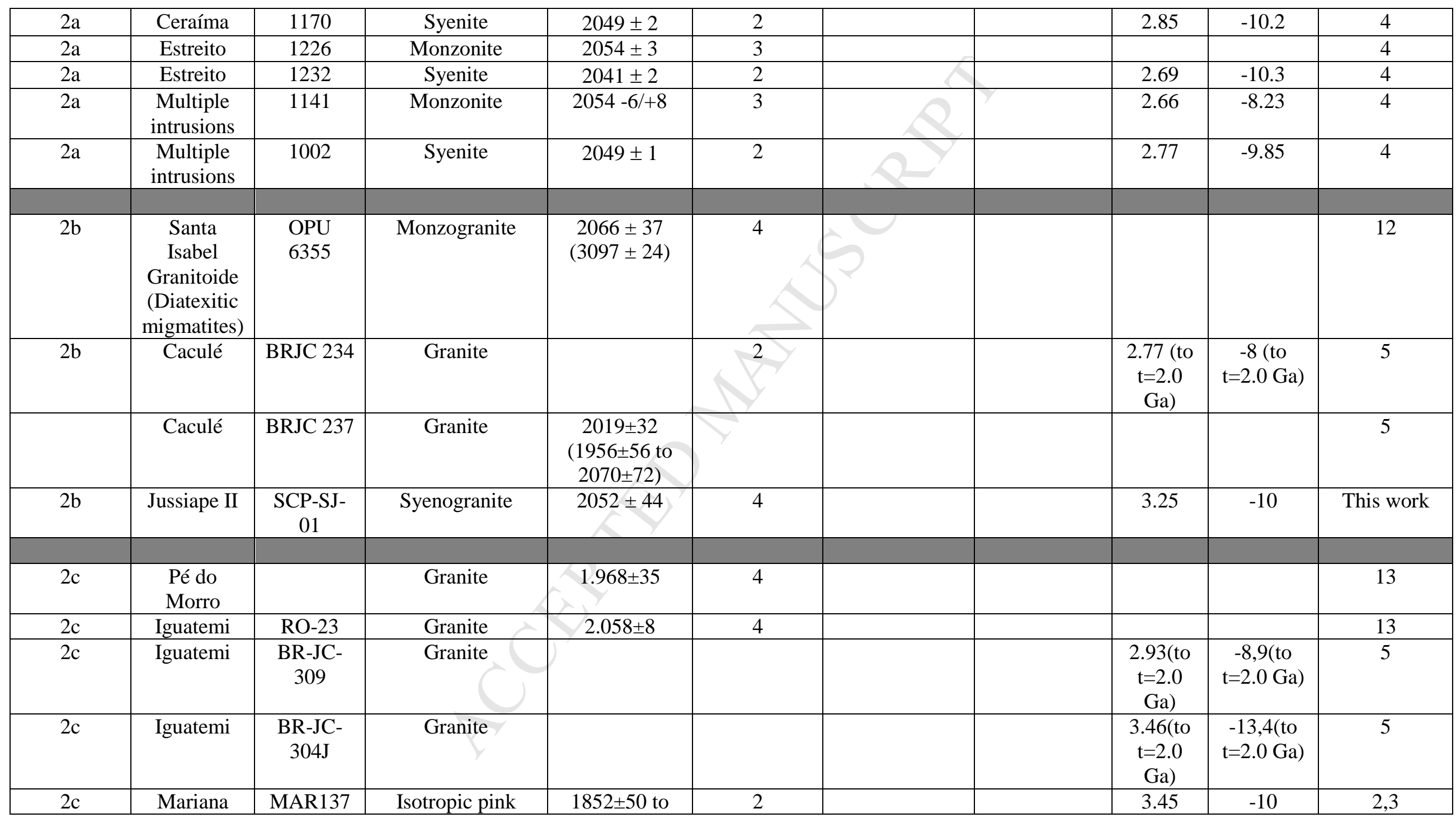




\begin{tabular}{|c|c|c|c|c|c|c|c|c|c|c|}
\hline & & & granite & $1944 \pm 14$ & & & & & & \\
\hline $2 c$ & $\begin{array}{l}\text { Serra da } \\
\text { Franga }\end{array}$ & SRF & $\begin{array}{c}\text { Isotropic } \\
\text { monzogranite }\end{array}$ & $2039 \pm 22$ & 2 & & & & & 2,3 \\
\hline $2 d$ & $\begin{array}{l}\text { Riacho da } \\
\text { Pedras }\end{array}$ & & Monzogranite & $1929 \pm 16$ & 6 & & & 3.16 & -6.2 & 1 \\
\hline $2 d$ & Broco & TB-05 & Granodiorite & $2038 \pm 8$ & 4 & $1964 \pm 9 *$ & 4 & 2.9 & -6.3 & This work \\
\hline $2 d$ & $\begin{array}{l}\text { Espírito } \\
\text { Santo }\end{array}$ & BR01/02 & Granite & $1997 \pm 32$ to & 2 & 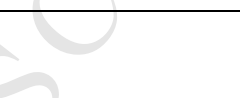 & & & & 5 \\
\hline $2 \mathrm{~d}$ & $\begin{array}{l}\text { Espírito } \\
\text { Santo }\end{array}$ & BR01/06 & Granite & $2023 \pm 26$ & & $Y$ & & & & 5 \\
\hline $2 d$ & $\begin{array}{l}\text { Espírito } \\
\text { Santo }\end{array}$ & BR01L & Granite & & & & & $\begin{array}{c}3.05 \text { (to } \\
\mathrm{t}=2.0 \\
\mathrm{Ga} \text { ) }\end{array}$ & $\begin{array}{c}-11,1 \\
\text { (to } \mathrm{t}=2.0 \\
\mathrm{Ga} \text { ) }\end{array}$ & 5 \\
\hline & & BR01S & Granite & & 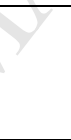 & & & $\begin{array}{c}3,09 \text { (to } \\
\mathrm{t}=2.0 \\
\mathrm{Ga})\end{array}$ & $\begin{array}{l}-12,0 \text { (to } \\
\mathrm{t}=2.0 \mathrm{Ga})\end{array}$ & \\
\hline $2 d$ & Umburana & ARN58-1 & $\begin{array}{l}\text { Isotrope anatetic } \\
\text { granite }\end{array}$ & $\begin{array}{c}(2570 \pm 20 \text { to } \\
2833 \pm 66)\end{array}$ & 2 & & & 3.30 & -14 & 2,3 \\
\hline $2 d$ & Umburana & ARN60-1 & $\begin{array}{l}\text { Granodiorite to } \\
\text { monzogranite }\end{array}$ & $\begin{array}{c}(2848 \pm 10 \text { to } \\
3103 \pm 8)\end{array}$ & 2 & & & 3.38 & -14 & 2,3 \\
\hline $2 \mathrm{~d}$ & Umburana & UMB 164 & $\begin{array}{l}\text { Granodiorite to } \\
\text { monzogranite }\end{array}$ & $\begin{array}{c}(3052 \pm 30 \text { to } \\
3130 \pm 14)\end{array}$ & 2 & & & 3.38 & -15 & 2,3 \\
\hline $2 \mathrm{~d}$ & Umburana & UMB 165 & $\begin{array}{l}\text { Granodiorite to } \\
\text { monzogranite }\end{array}$ & $\begin{array}{l}(2791 \pm 8 \text { to } \\
3006 \pm 18)\end{array}$ & 2 & $\begin{array}{l}2002 \pm 26 \text { to } \\
2049 \pm 12\end{array}$ & 2 & 3.35 & -15 & 10 \\
\hline $2 d$ & Umburana & UMB 165 & $\begin{array}{l}\text { Granodiorite to } \\
\text { monzogranite }\end{array}$ & & & $\begin{array}{c}1962 \pm 13 \text { to } \\
2053 \pm 17\end{array}$ & 5 & & & 10 \\
\hline $2 \mathrm{~d}$ & Umburana & UMB 165 & $\begin{array}{l}\text { Granodiorite to } \\
\text { monzogranite }\end{array}$ & & & $\begin{array}{c}1971 \pm 10 \text { and } \\
2.50\end{array}$ & 4 & & & 10 \\
\hline $2 \mathrm{~d}$ & $\begin{array}{l}\text { Lagoinha- } \\
\text { Lagoa }\end{array}$ & & Granite & $1974 \pm 36$ & 6 & & & & & 1 \\
\hline
\end{tabular}




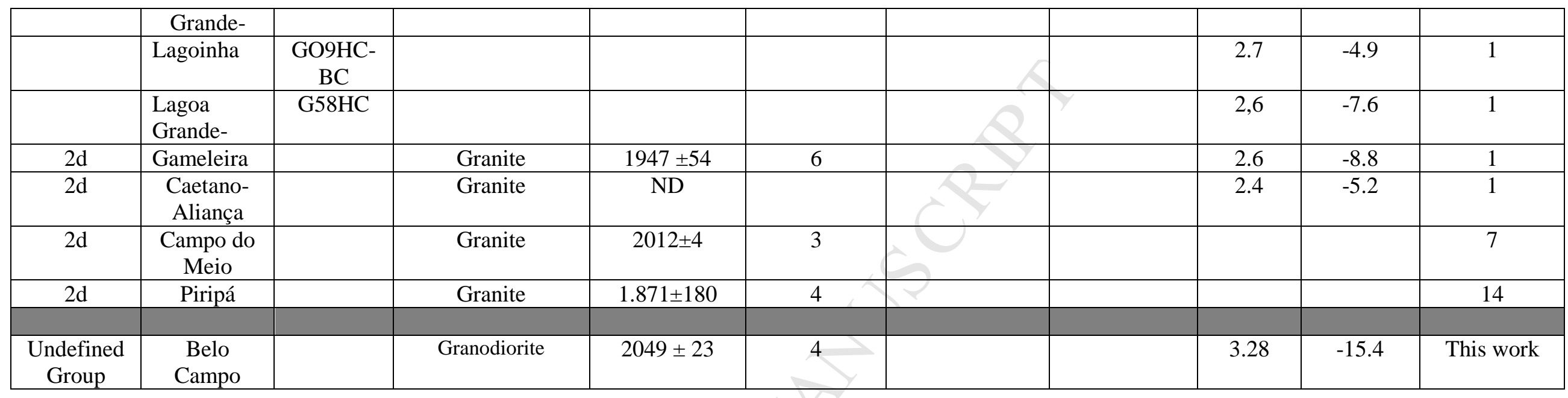




\section{Table 2}

\begin{tabular}{|c|c|c|c|c|c|c|c|c|c|c|c|c|c|c|c|c|c|c|c|}
\hline & $\mathrm{U}$ & $\mathrm{Pb}$ & Th & \multicolumn{3}{|c|}{ Isotopic ratios } & & & & & & & Ages in Ma & & & & & & \\
\hline \multirow{2}{*}{\multicolumn{2}{|c|}{\begin{tabular}{|l|c|} 
& ppm \\
Jussiape Gran
\end{tabular}}} & $\mathrm{ppm}$ & $\mathrm{ppm}$ & Th/U & $206 \mathrm{~Pb} / 204 \mathrm{P}$ & $\begin{array}{ll}\text { b } & 207 \mathrm{~Pb} / 206 \mathrm{~Pb} \\
\end{array}$ & $\pm 1 \mid(\%)$ & $207 \mathrm{~Pb} / 235 \mathrm{U}$ & $\pm 1 \mid(\%)$ & $206 \mathrm{~Pb} / 238 \mathrm{U}$ & $\pm 1(\%)$ & Rho & $207 \mathrm{~Pb} / 235 \mathrm{U}$ & \pm 1 & $206 \mathrm{~Pb} / 238 \mathrm{U}$ & \pm 1 & $207 \mathrm{~Pb} / 206 \mathrm{~Pb}$ & \pm 1 & Conc (\%) \\
\hline \multirow{2}{*}{\multicolumn{20}{|c|}{$\begin{array}{l}\text { Jussiape Granite, sample SCP SJ01. Coordinate: } 24 \text { L } 220332 \text { / } 8505202 \\
\text { LA-ICPMS analyses Brasilia / Brazil }\end{array}$}} \\
\hline & & & & & & & & & & & & & & & & & & & \\
\hline \multicolumn{20}{|c|}{ euhedral zircons ca $2.0 \mathrm{Ga}$} \\
\hline $\mathrm{Z2}$ & - & - & - & - & - & 0,1199 & 6,7 & 5,091 & 5,5 & 0,3078 & 3,8 & 0,85 & 1835 & 45 & 1730 & 58 & 1955 & 114 & 88 \\
\hline 25 & - & - & - & 0,32 & 19039 & 0,1176 & 6,3 & 2,956 & 8,9 & 0,1823 & 6,3 & 0,89 & 1396 & 67 & 1080 & 62 & 1920 & 112 & 56 \\
\hline 27 & - & - & - & 0,27 & 27025 & 0,1331 & 10,2 & 6,986 & 8,4 & 0,3808 & 5,9 & 0,94 & 2110 & 72 & 2080 & 104 & 2139 & 169 & 97 \\
\hline 28 & - & - & - & 0,20 & 100561 & 0,1190 & 14,8 & 3,706 & 12,3 & 0,2259 & 8,1 & 0,96 & 1573 & 94 & 1313 & \begin{tabular}{|l|}
97 \\
\end{tabular} & 1941 & 244 & 68 \\
\hline 29 & - & - & - & 0,02 & 6482 & 0,1216 & 7,7 & 4,929 & 6,3 & 0,2939 & 4,4 & 0,86 & 1807 & \begin{tabular}{|l|}
52 \\
\end{tabular} & 1661 & 64 & 1980 & 130 & 84 \\
\hline Z10 & - & - & - & - & 25150 & 0,1229 & 10,0 & 4,337 & 8,2 & 0,2559 & 5,7 & 0,002 & 1700 & $\begin{array}{l}65 \\
65\end{array}$ & 1469 & $\begin{array}{l}75 \\
\end{array}$ & 1999 & 167 & 73 \\
\hline Z11 & - & - & - & 0,18 & 593 & 0,1357 & 4,5 & 7,261 & 6,2 & 0,3881 & 4,4 & 0,79 & 2144 & 56 & 2114 & 78 & 2173 & 78 & 97 \\
\hline 212 & - & - & - & 0,03 & 64775 & 0,1275 & 10,3 & 6,428 & 8,4 & 0,3658 & 5,9 & 0,93 & 2036 & \begin{tabular}{|l|}
72 \\
\end{tabular} & 2010 & 101 & 2063 & 171 & 97 \\
\hline Z13 & - & - & - & 0,92 & 654 & 0,1336 & 8,8 & 4,226 & 7,4 & 0,2293 & 4,7 & 0,87 & 1679 & 59 & 1331 & \begin{tabular}{|l|}
58 \\
\end{tabular} & 2146 & 147 & 62 \\
\hline Z15 & - & - & - & 0,02 & 16377 & 0,1309 & 4,3 & 8,959 & 6,0 & 0,4965 & 4,1 & 0,86 & 2334 & \begin{tabular}{|l|}
54 \\
\end{tabular} & 2599 & 88 & 2110 & 75 & 123 \\
\hline Z16 & - & - & - & 0,04 & 210602 & 0,1272 & 4,7 & 7,415 & 6,6 & 0,4226 & 4,5 & 0,87 & 2163 & 59 & 2272 & \begin{tabular}{|l|}
87 \\
\end{tabular} & 2060 & 84 & 110 \\
\hline Z17 & - & - & - & 0,31 & 7400 & 0,1269 & 7,2 & 5,815 & 6,0 & 0,3324 & 4,1 & 0,85 & 1949 & \begin{tabular}{|l|}
50 \\
\end{tabular} & 1850 & 65 & 2055 & 122 & 90 \\
\hline Z19 & - & - & - & 0,02 & 25801 & 0,1234 & 5,8 & 6,427 & 8,2 & 0,3777 & 5,8 & 0,92 & 2036 & \begin{tabular}{|l|}
72 \\
72
\end{tabular} & 2066 & \begin{tabular}{|l|}
102 \\
\end{tabular} & 2006 & 104 & 103 \\
\hline$\frac{15}{720}$ & - & - & & 0,01 & 129780 & 0,1255 & 3,9 & 6,507 & 5,4 & 0,3761 & 3,7 & 0,85 & 2047 & \begin{tabular}{|l|l}
48 \\
\end{tabular} & 2058 & 65 & 2036 & 69 & 101 \\
\hline \multirow{2}{*}{\multicolumn{20}{|c|}{$\frac{220}{\mathrm{cores}}$ and inherited zircons ca $2.7 \& 3.1 \mathrm{Ga}$}} \\
\hline & - & - & - & - & - & 0,1738 & 7,5 & 10,395 & 6,1 & 0,4337 & 4,3 & 0,88 & 2471 & 55 & 2322 & 83 & 2595 & 119 & 89 \\
\hline 23 & - & - & - & - & - & 0,1594 & 9,7 & 8,701 & $\frac{1,1}{7,9}$ & 0,3959 & 5,6 & 0,89 & 2307 & 70 & 2150 & \begin{tabular}{|l|}
101 \\
\end{tabular} & 2449 & 155 & 88 \\
\hline 24 & - & - & - & - & - & 0,1847 & 6,4 & 12,157 & $\frac{1,5}{5,2}$ & 0,4773 & 3,7 & 0,89 & 2617 & 48 & 2515 & $\begin{array}{l}77 \\
\end{array}$ & 2696 & 102 & 93 \\
\hline 26 & - & - & - & 0,08 & 1267 & 0,1851 & 8,5 & 12,372 & 6,9 & 0,4848 & 4,9 & 0,92 & 2633 & \begin{tabular}{|l|}
63 \\
63
\end{tabular} & 2548 & 102 & 2699 & 133 & 94 \\
\hline Z14 & - & - & - & 0,07 & 17954 & 0,2397 & 7,3 & 20,279 & 6,0 & 0,6135 & 4,1 & 0,86 & 3105 & 57 & 3084 & 101 & 3118 & 112 & 99 \\
\hline Z18 & - & - & - & $\begin{array}{l}0,04 \\
\end{array}$ & \begin{tabular}{l|l}
1 & 17034 \\
\end{tabular} & $\begin{array}{l}0,1834 \\
\end{array}$ & $\begin{array}{l}, 3 \\
3,8 \\
\end{array}$ & 13,160 & 5,3 & 0,5205 & $\frac{3,1}{3,6}$ & 0,84 & 2691 & \begin{tabular}{|l|}
50 \\
\end{tabular} & 2701 & $\frac{11}{80}$ & 2684 & $\frac{112}{64}$ & 101 \\
\hline \multirow{2}{*}{\multicolumn{20}{|c|}{$\begin{array}{l}\text { Lagoa das Almas Granite, sample ( L-05). Coordinate: } 23 \text { L } 777329 \text { / } 8351468 \\
\text { LA-ICPMS analyses Brasilia / Brazil }\end{array}$}} \\
\hline & & & & & & & & & & & & & & & & & & & \\
\hline $\mathrm{Z1}$ & 723 & 248 & 23 & 0,03 & - & 0,1229 & 0,82 & 4,980 & 1,8 & 0,2939 & 1,62 & 0,89 & 1816 & 33 & 1661 & 27 & 1998 & 16 & 84 \\
\hline $\mathrm{Z2}$ & 502 & 187 & 152 & 0,30 & - & 0,1321 & 0,85 & 7,009 & 2,4 & 0,3847 & 2,19 & 0,93 & 2113 & \begin{tabular}{|l|l|}
50 \\
\end{tabular} & 2098 & 46 & 2127 & 18 & 99 \\
\hline Z3-1 & 535 & 159 & 57 & 0,11 & - & & 0,87 & 7,152 & 3,1 & 0,3974 & 2,98 & 0,96 & 2131 & 66 & 2157 & 64 & 2105 & 18 & 102 \\
\hline $23-2$ & 445 & 192 & 95 & 0,21 & - & 0,1328 & 0,79 & $\frac{1,102}{7,535}$ & $\frac{2,1}{2,3}$ & 0,4115 & $\frac{2,70}{2,12}$ & 0,94 & 2177 & 49 & 2222 & 47 & 2136 & 17 & 104 \\
\hline 24 & 598 & 220 & 555 & 0,93 & - & 0,1326 & 0,78 & $\frac{1,050}{7,555}$ & $\frac{15}{1,8}$ & 0,4132 & $\frac{2,12}{1,64}$ & 0,90 & 2180 & \begin{tabular}{|l|}
40 \\
40
\end{tabular} & 2230 & 37 & 2133 & 17 & 105 \\
\hline 25 & 125 & 52 & 39 & 0,31 & - & 0,1322 & 1,58 & 7,249 & 2,1 & $\frac{1,4132}{0,3975}$ & 1,32 & 0,64 & 2142 & \begin{tabular}{|l|l|}
44 \\
44
\end{tabular} & 2158 & \begin{tabular}{|l|}
29 \\
29
\end{tabular} & 2128 & 34 & 101 \\
\hline Z6 & 258 & 110 & 28 & 0,11 & - & 0,12 & 1,53 & 6,471 & 2,6 & 0,3664 & 2,16 & 0,82 & 2042 & 54 & 2012 & 43 & 2072 & 32 & 97 \\
\hline 27 & 53 & 29 & 19 & 0,35 & $\begin{array}{ll}- & \\
-\end{array}$ & 0,1434 & 1,73 & 8,143 & 2,5 & 0,4119 & 1,88 & 0,74 & 2247 & \begin{tabular}{|l|}
57 \\
\end{tabular} & 2224 & 42 & 2268 & 39 & 98 \\
\hline 28 & 591 & 238 & 82 & 0,14 & - & 0,1294 & 1,53 & 6,610 & 1,9 & 0,3706 & 1,15 & 0,60 & 2061 & \begin{tabular}{|l|}
39 \\
\end{tabular} & 2032 & \begin{tabular}{|l|}
23 \\
\end{tabular} & 2089 & 32 & 97 \\
\hline 20 & 1324 & 301 & 341 & 0,26 & - & 0,1152 & 1,91 & 3,520 & 2,4 & 0,2216 & 1,38 & 0,59 & 1532 & 36 & 1290 & \begin{tabular}{|l|}
25 \\
18
\end{tabular} & 1883 & 36 & 69 \\
\hline$\frac{29}{Z 10}$ & $\frac{1324}{2708}$ & $\frac{301}{398}$ & $\begin{array}{l}341 \\
199\end{array}$ & $\begin{array}{l}0,26 \\
0,07\end{array}$ & & $\frac{0,1152}{0,0954}$ & $\frac{1,91}{2,21}$ & $\begin{array}{l}3,200 \\
2,271\end{array}$ & $\frac{2,4}{2,6}$ & $\frac{0,2216}{0,1727}$ & $\begin{array}{l}1,38 \\
1,43\end{array}$ & $\begin{array}{l}0,59 \\
0,54\end{array}$ & $\begin{array}{l}1532 \\
1203\end{array}$ & \begin{tabular}{|l|}
36 \\
32 \\
\end{tabular} & $\begin{array}{l}1290 \\
1027\end{array}$ & \begin{tabular}{|l|l|}
15 \\
15
\end{tabular} & $\begin{array}{l}1883 \\
1536\end{array}$ & $\frac{36}{34}$ & $\frac{69}{67}$ \\
\hline
\end{tabular}


Table 2 ..cont.

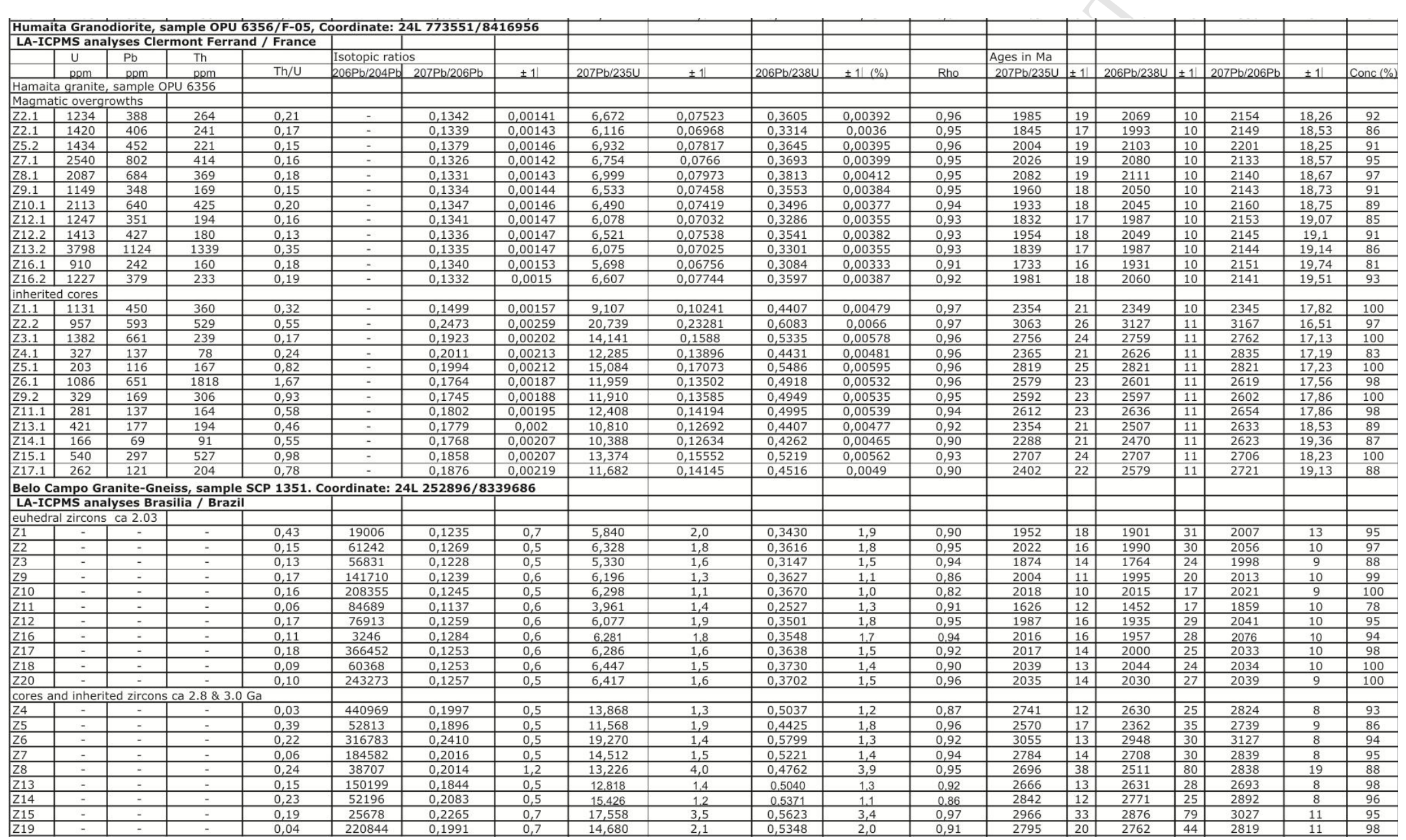


Table 2 ..cont

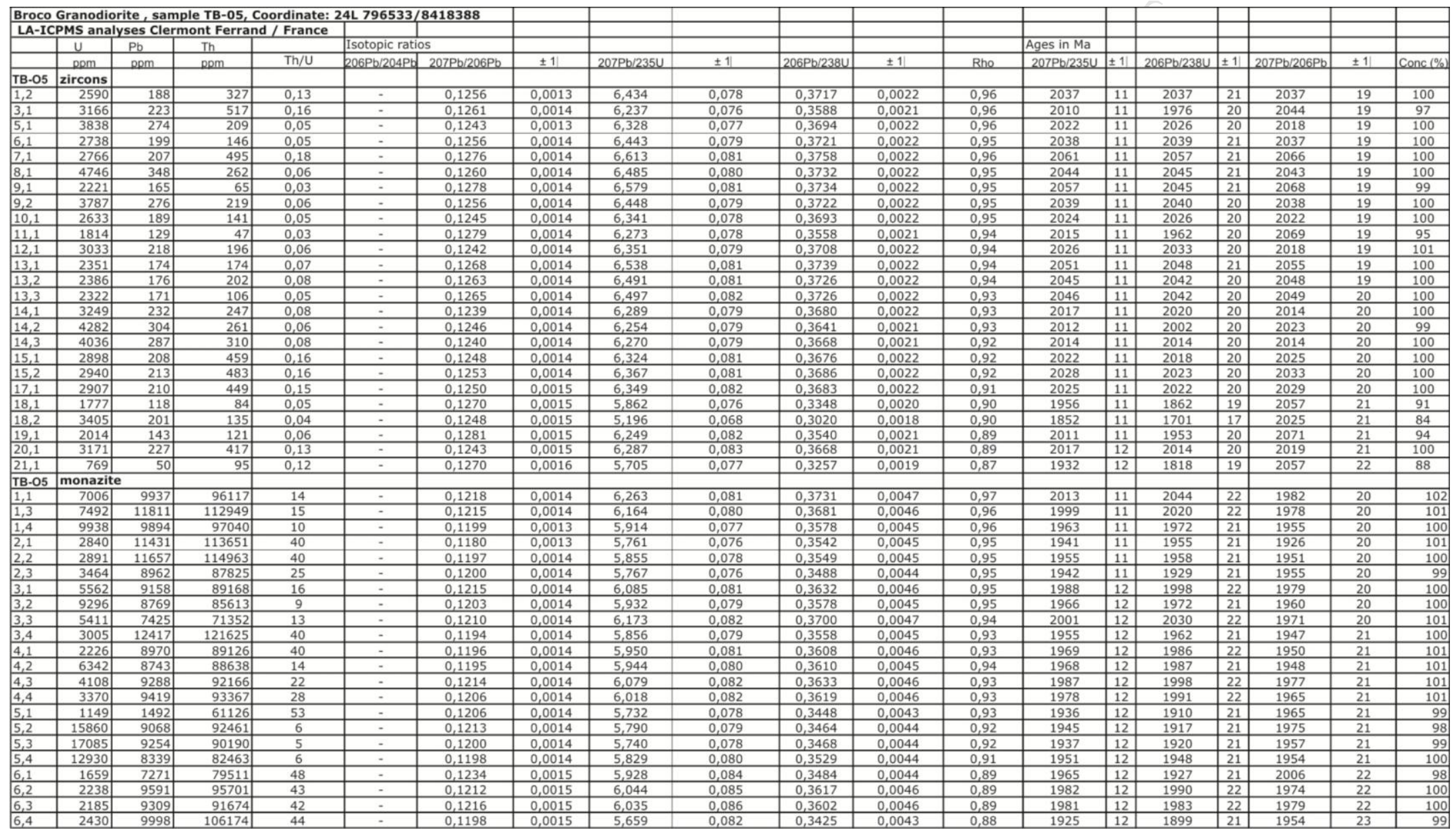


Table 3.

1

2

3 
Table 4

\begin{tabular}{|c|c|c|c|c|c|c|c|c|c|}
\hline ID & SCP-1449a1 & SCP-1449a2 & SCP- $1449 c$ & SCP-2019.5J & SCP-SJ01 & SCP-SJ-24b & SCP-1449b & SCP-2035b & SCP-2035c \\
\hline $\begin{array}{c}\text { General } \\
\text { classification }\end{array}$ & Syenogranite & Syenogranite & $\begin{array}{l}\text { Quartz- } \\
\text { syenite }\end{array}$ & $\begin{array}{l}\text { Quartz- } \\
\text { syenite }\end{array}$ & Syenogranite & Syenogranite & Syenogranite & Syenogranite & Syenogranite \\
\hline $\mathrm{SiO}_{2}$ & 74,80 & 74,80 & 66,70 & 67,07 & 72,80 & 76,90 & 75,70 & 74,90 & 73,40 \\
\hline $\mathrm{TiO}_{2}$ & 0,17 & 0,16 & 0,49 & 0,32 & 0,24 & 0,41 & 0,48 & 0,26 & 0,17 \\
\hline $\mathrm{Al}_{2} \mathrm{O}_{3}$ & 13,00 & 13,20 & 18,50 & 18,02 & 13,70 & 11,90 & 11,70 & 12,90 & 13,60 \\
\hline $\mathrm{FeO}$ & 0,87 & 0,79 & 3,19 & 3,18 & 1,03 & 1,73 & 4,56 & 4,36 & 0,88 \\
\hline $\mathrm{Fe}_{2} \mathrm{O}_{3}$ & 1,38 & 1,42 & 1,43 & 0,70 & 1,72 & 1,87 & 2,23 & 2,44 & 2,50 \\
\hline MnO & 0,02 & 0,02 & 0,04 & 0,02 & 0,02 & 0,04 & 0,03 & 0,03 & 0,03 \\
\hline MgO & 0,24 & 0,24 & 0,49 & 0,24 & 0,44 & 0,38 & 0,33 & 0,31 & 0,24 \\
\hline $\mathrm{CaO}$ & 1,03 & 1,10 & 3,36 & 1,76 & 1,16 & 0,80 & 0,95 & 1,14 & 1,22 \\
\hline $\mathrm{Na}_{2} \mathrm{O}$ & 3,20 & 3,10 & 9,10 & 5,39 & 3,10 & 2,70 & 3,00 & 3,20 & 3,30 \\
\hline $\mathrm{K}_{2} \mathrm{O}$ & 5,50 & 5,40 & 0,51 & 6,40 & 5,50 & 5,20 & 4,40 & 4,80 & 5,00 \\
\hline $\mathrm{P}_{2} \mathrm{O}_{5}$ & 0,04 & 0,04 & 0,10 & 0,12 & 0,10 & 0,08 & 0,07 & 0,04 & 0,04 \\
\hline LOI & 0,20 & 0,10 & 0,10 & 0,21 & 0,13 & 0,14 & 0,12 & 0,11 & 0,13 \\
\hline Total & 99,58 & 99,58 & 100,82 & 100,25 & 98,91 & 100,42 & 99,01 & 100,13 & 99,63 \\
\hline Ba & & & & & 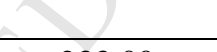 & & & & \\
\hline Cs & $1 / 8,00$ & 199,00 & 860,00 & 359,80 & 233,00 & 559,00 & 966,00 & 730,00 & 721,00 \\
\hline & $3 \mathrm{~J}, \mathrm{UU}$ & 55,00 & & 10,40 & $4+, 00$ & 35,00 & $<0.05$ & $<0.05$ & $<0.05$ \\
\hline & 210,00 & & & & $5 \angle 1,00$ & 489,00 & 415,00 & 729,00 & 514,00 \\
\hline & 10,00 & & $2 \angle, 00$ & & 20,00 & 12,00 & 21,00 & 19,00 & 19,00 \\
\hline & & & & 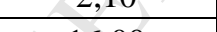 & 4,50 & 4,40 & 4,50 & 5,20 & 1,40 \\
\hline $\mathbf{R b}$ & 5600 & $\frac{11,00}{5500}$ & $\frac{15,00}{40,00}$ & 33,40 & $\frac{12,00}{78,00}$ & $\frac{12,00}{13800}$ & $\frac{39,00}{10400}$ & $\frac{24,00}{28200}$ & $\frac{29,00}{29200}$ \\
\hline $\mathrm{Sr}$ & 62,00 & 57,00 & 82,00 & 137,10 & 109,00 & 118,00 & 8,00 & 21,00 & 24,00 \\
\hline Ta & 18,00 & 20,00 & 30,00 & 23,80 & 22,00 & 18,00 & 12,00 & 12,00 & 14,00 \\
\hline Th & 45,10 & 19,20 & 67,00 & 116,00 & 83,70 & 106,00 & 34,20 & 119,00 & 117,00 \\
\hline $\mathbf{U}$ & 7,40 & 24,00 & 21,40 & 11,50 & 42,30 & 7,45 & 4,65 & 29,00 & 46,00 \\
\hline $\mathbf{Y}$ & 22,50 & 22,30 & 58,40 & 44,40 & 40,50 & 112,00 & 41,40 & 70,00 & 146,00 \\
\hline $\mathbf{Z r}$ & 9,00 & 9,30 & 9,20 & 9,10 & 8,55 & 9,55 & 599,00 & 232,00 & 197,00 \\
\hline
\end{tabular}




\begin{tabular}{|c|c|c|c|c|c|c|c|c|c|}
\hline $\mathrm{Ce}$ & 113,00 & 225,00 & 347,00 & 308,80 & 201,00 & 479,00 & 287,00 & 176,00 & 306,00 \\
\hline Dy & 5,06 & 5,07 & 14,10 & 8,21 & 9,08 & 25,50 & 10,00 & 6,18 & 17,00 \\
\hline Er & 2,07 & 2,06 & 5,77 & 2,55 & 3,66 & 9,63 & 3,73 & 3,61 & 8,77 \\
\hline Eu & 0,97 & 0,98 & 1,91 & 1,27 & 1,14 & 3,96 & 1,87 & 1,36 & 2,29 \\
\hline Gd & 7,04 & 8,13 & 24,50 & 16,38 & 14,30 & 46,50 & 17,10 & 9,01 & 20,20 \\
\hline Ho & 0,87 & 1,02 & 2,34 & 1,10 & 1,50 & 4,34 & 1,63 & 1,25 & 3,19 \\
\hline La & 53,20 & 52,20 & 159,00 & 142,50 & 94,20 & 335,00 & 136,00 & 92,30 & 210,00 \\
\hline Lu & 0,24 & 0,34 & 0,63 & 0,31 & 0,41 & 0,75 & 0,34 & 0,51 & 0,99 \\
\hline Nd & 36,40 & 40,05 & 128,00 & 132,30 & 76,80 & 223,00 & 99,90 & 56,40 & 123,00 \\
\hline Pr & 12,20 & 12,20 & 41,20 & 40,30 & 25,10 & 69,50 & 33,00 & 33,00 & 19,50 \\
\hline Sm & 7,10 & 8,05 & 27,10 & 21,80 & 17,60 & 45,20 & 19,00 & 10,40 & 23,70 \\
\hline $\mathbf{T b}$ & 1,10 & 1,10 & 3,20 & 3,80 & 2,00 & 5,92 & 2,32 & 1,26 & 3,29 \\
\hline Tm & 0,25 & 0,25 & 0,72 & 0,22 & 0,44 & 1,05 & 0,40 & 0,51 & 1,16 \\
\hline $\mathbf{Y b}$ & 1,60 & 2,00 & 4,40 & 1,85 & 2,90 & 5,50 & 2,30 & 3,30 & 7,60 \\
\hline
\end{tabular}

Cont...

\begin{tabular}{|c|c|c|c|c|c|c|c|c|}
\hline ID & SCP-SJ-24a & SCP-SJ-28 & SCP-SJ-04 & SCP-1858 & SCP-1723 & SCP-1726 & SCP-1828 & SCP-1822 \\
\hline & Syenogranite & Syenogranite & Syenogranite & Syenogranite & Syenogranite & Syenogranite & Syenogranite & Syenogranite \\
\hline $\mathbf{S i O}_{\mathbf{2}}$ & 72,80 & 76,20 & 73,80 & 72,20 & 73,00 & 74,00 & 74,20 & 75,30 \\
\hline $\mathbf{T i O}_{\mathbf{2}}$ & 0,41 & 0,41 & 0,16 & 0,22 & 0,16 & 0,26 & 0,15 & 0,11 \\
\hline $\mathbf{A l}_{\mathbf{2}} \mathbf{O}_{\mathbf{3}}$ & 11,70 & 11,70 & 13,90 & 13,40 & 14,60 & 13,10 & 13,40 & 13,50 \\
\hline $\mathbf{F e O}$ & 4,54 & 1,44 & 0,62 & 0,50 & 1,00 & 1,33 & 0,84 & 0,77 \\
\hline $\mathbf{F e}_{\mathbf{2}} \mathbf{O}_{\mathbf{3}}$ & 2,48 & 2,41 & 1,42 & 2,20 & 0,79 & 1,21 & 1,14 & 0,99 \\
\hline $\mathbf{M n O}$ & 0,03 & 0,04 & 0,03 & 0,03 & 0,01 & 0,02 & 0,03 & 0,01 \\
\hline $\mathbf{M g O}$ & 0,33 & 0,43 & 0,36 & 0,40 & 0,28 & 0,34 & 0,25 & 0,28 \\
\hline $\mathbf{C a O}$ & 1,10 & 1,75 & 0,80 & 1,06 & 0,59 & 0,80 & 0,66 & 0,97 \\
\hline $\mathbf{N a} \mathbf{O}$ & 2,80 & 3,20 & 3,40 & 3,00 & 3,60 & 3,10 & 3,40 & 3,70 \\
\hline
\end{tabular}




\begin{tabular}{|c|c|c|c|c|c|c|c|c|}
\hline $\mathbf{K}_{2} \mathbf{O}$ & 4,40 & 2,90 & 5,20 & 5,50 & 6,00 & 6,00 & 5,50 & 5,00 \\
\hline $\mathbf{P}_{2} \mathbf{O}_{5}$ & 0,07 & 0,07 & 0,09 & 0,09 & 0,09 & 0,12 & 0,03 & 0,04 \\
\hline LOI & & 0,02 & 0,21 & 0,44 & 0,24 & 0,39 & 0,37 & 0,17 \\
\hline Total & 100,66 & 100,57 & 99,99 & 99,04 & 100,36 & 100,67 & 99,97 & 100,84 \\
\hline $\mathbf{B a}$ & 816,00 & 790,00 & 399,00 & 410,00 & 608,00 & 464,00 & 362,00 & 384,00 \\
\hline Cs & ND & ND & ND & ND & ND & ND & ND & ND \\
\hline $\mathbf{F}$ & 341,00 & 502,00 & 202,00 & 315,00 & 211,00 & 360,00 & 249,00 & 286,00 \\
\hline Ga & 18,00 & 20,00 & 22,00 & 21,00 & 23,00 & 22,00 & 23,00 & 22,00 \\
\hline Hf & 5,40 & 6,10 & 6,50 & 7,20 & 8,20 & 2,20 & 2,40 & 2,30 \\
\hline $\mathbf{N b}$ & 38,00 & 45,00 & 45,00 & 55,00 & 25,00 & 59,00 & 36,00 & 16,00 \\
\hline $\mathbf{R b}$ & 199,00 & 168,00 & 401,00 & 357,00 & 343,00 & 307,00 & 394,00 & 272,00 \\
\hline $\mathbf{S r}$ & & 23,00 & 57,00 & 15,00 & 47,00 & 11,00 & 11,00 & 47,00 \\
\hline Ta & 16,00 & 3,10 & 8,20 & 5,20 & 7,90 & 6,30 & 8,20 & 9,10 \\
\hline Th & 97,00 & 28,00 & 52,10 & 80,00 & 58,70 & 75,40 & 52,60 & 45,40 \\
\hline $\mathbf{U}$ & 16,00 & 27,00 & 19,40 & 31,90 & 25,00 & 21,10 & 14,40 & 5,66 \\
\hline $\mathbf{Y}$ & 65,00 & 113,00 & 83,90 & 119,00 & 156,00 & 104,00 & 83,50 & 73,50 \\
\hline $\mathbf{Z r}$ & 621,00 & 613,00 & 173,00 & 197,00 & 176,00 & 225,00 & 142,00 & 130,00 \\
\hline & & & & & $\mathrm{N}$ & & & \\
\hline $\mathrm{Ce}$ & 274,00 & 296,00 & 124,00 & 199,00 & 130,00 & 200,00 & 146,00 & 121,00 \\
\hline Dy & 10,50 & 14,30 & 12,10 & 20,70 & 20,90 & 18,10 & 14,40 & 11,60 \\
\hline $\mathbf{E r}$ & 3,84 & 7,31 & 7,01 & 11,80 & 14,60 & 9,64 & 8,21 & 7,09 \\
\hline $\mathbf{E u}$ & 1,49 & 2,23 & 0,75 & 0,95 & 1,19 & 1,09 & 0,85 & 0,71 \\
\hline Gd & 17,80 & 19,50 & 12,20 & 18,70 & 17,50 & 21,70 & 14,10 & 10,80 \\
\hline Ho & 1,71 & 2,84 & 2,44 & 4,16 & 4,79 & 3,62 & 2,78 & 2,39 \\
\hline $\mathbf{L a}$ & 130,00 & 165,00 & 64,60 & 93,90 & 73,80 & 87,20 & 84,60 & 57,80 \\
\hline $\mathbf{L u}$ & 0,37 & 0,78 & 0,99 & 1,56 & 2,16 & 0,95 & 1,21 & 0,96 \\
\hline Nd & 99,80 & 117,00 & 51,90 & 77,30 & 55,10 & 77,30 & 61,60 & 44,70 \\
\hline $\operatorname{Pr}$ & 44,30 & 31,00 & 16,90 & 25,30 & 17,00 & 24,00 & 19,70 & 14,80 \\
\hline $\mathrm{Sm}$ & 19,10 & 22,60 & 13,00 & 19,70 & 13,80 & 20,10 & 15,10 & 11,30 \\
\hline $\mathbf{T b}$ & 2,44 & 2,88 & 2,16 & 3,45 & 3,28 & 3,38 & 2,48 & 1,98 \\
\hline $\mathrm{Tm}$ & 0,44 & 0,85 & 0,94 & 1,67 & 2,22 & 1,22 & 1,21 & 0,99 \\
\hline
\end{tabular}


Table 5

\begin{tabular}{|c|c|c|c|c|c|c|c|c|c|c|c|}
\hline ID & L-45 & L-46 & L-50 & L-52 & L-52 & L-59 & L-05A & L-16A & L-22 & L-40 & L-44A \\
\hline $\begin{array}{c}\text { General } \\
\text { classification }\end{array}$ & Granodiorite & Granodiorite & Granodiorite & Granodiorite & Granodiorite & Granodiorite & Granodiorite & Granodiorite & Granodiorite & Granodiorite & Granodiorite \\
\hline $\mathrm{SiO}_{2}$ & 72,70 & 73,80 & 73,50 & 66,20 & 66,90 & 68,30 & 73,60 & 71,50 & 71,10 & 71,00 & 70,30 \\
\hline $\mathrm{TiO}_{2}$ & 0,26 & 0,18 & 0,20 & 0,50 & 0,50 & 0,43 & 0,19 & 0,22 & 0,35 & 0,37 & 0,38 \\
\hline $\mathrm{Al}_{2} \mathrm{O}_{3}$ & 14,20 & 14,00 & 14,10 & 16,10 & 16,30 & 15,50 & 14,50 & 15,40 & 14,50 & 14,60 & 14,60 \\
\hline FeO & 1,77 & 1,57 & 2,21 & 2,69 & 2,87 & 2,99 & 0,38 & 0,89 & 0,99 & 0,94 & 0,27 \\
\hline $\mathrm{Fe}_{2} \mathrm{O}_{3}$ & 2,83 & 2,17 & 2,72 & 4,85 & 4,51 & 3,91 & 1,64 & 1,29 & 2,14 & 2,13 & 2,63 \\
\hline $\mathrm{MnO}$ & 0,04 & 0,03 & 0,03 & 0,05 & 0,05 & 0,04 & 0,03 & 0,02 & 0,05 & 0,04 & 0,06 \\
\hline MgO & 0,45 & 0,38 & 0,41 & 1,46 & 1,47 & 1,01 & 0,60 & 0,49 & 0,96 & 0,91 & 0,61 \\
\hline $\mathrm{CaO}$ & 1,27 & 1,29 & 1,53 & 2,44 & 2,44 & 2,81 & 0,50 & 0,53 & 1,54 & 0,99 & 1,89 \\
\hline $\mathrm{Na}_{2} \mathrm{O}$ & 3,90 & 3,97 & 4,23 & 5,60 & 5,70 & 4,75 & 5,30 & 3,60 & 3,50 & 3,60 & 3,70 \\
\hline $\mathbf{K}_{2} \mathbf{O}$ & 3,87 & 4,23 & 3,34 & 1,69 & 1,71 & 2,12 & 3,30 & 5,50 & 4,90 & 4,30 & 4,40 \\
\hline $\mathbf{P}_{2} \mathbf{O}_{5}$ & 0,08 & 0,08 & 0,06 & 0,19 & 0,19 & 0,13 & 0,16 & 0,09 & 0,13 & 0,15 & 0,11 \\
\hline LOI & 0,02 & 0,15 & 0,08 & 0,03 & 0,01 & 0,01 & 0,01 & 0,15 & 0,03 & 0,03 & 0,01 \\
\hline Total & 101,39 & 101,85 & 102,41 & 101,80 & 102,65 & 102,00 & 100,21 & 99,68 & 100,19 & 99,06 & 98,96 \\
\hline & & & & & 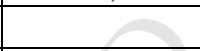 & & & & & & \\
\hline $\mathbf{B a}$ & 732,00 & 862,00 & 600,00 & 659,00 & 625,00 & 1296,00 & 632,00 & 1039,00 & 1644,00 & 8,33 & 1685,00 \\
\hline $\mathbf{F}$ & 610,00 & 384,00 & 1543,00 & 1425,00 & 424,00 & 502,00 & 147,00 & 197,00 & 397,00 & 443,00 & 1339,00 \\
\hline Ga & 26,00 & 25,00 & 27,00 & 21,00 & 23,00 & 23,00 & 22,00 & 22,00 & 19,00 & 17,00 & 25,00 \\
\hline Hf & 5,00 & 7,00 & 6,00 & 8,00 & 7,00 & 6,00 & 8,00 & 7,00 & 6,00 & 5,00 & 8,00 \\
\hline $\mathrm{Nb}$ & 9,00 & 17,00 & 22,00 & 9,00 & 10,00 & 8,00 & 17,00 & 23,00 & 12,00 & 19,00 & 18,00 \\
\hline $\mathbf{R b}$ & 191,00 & 193,00 & 172,00 & 78,00 & 68,00 & 80,00 & 193,00 & 361,00 & 198,00 & 208,00 & 214,00 \\
\hline $\mathrm{Sr}$ & 196,00 & 198,00 & 188,00 & 575,00 & 575,00 & 808,00 & 58,00 & 151,00 & 286,00 & 334,00 & 755,00 \\
\hline Ta & 0,50 & 0,45 & 0,44 & 0,54 & 0,54 & 0,55 & 0,54 & 0,70 & 0,88 & 0,66 & 0,66 \\
\hline Th & 15,00 & 5,00 & 14,00 & 22,00 & 22,00 & 22,00 & 13,60 & 29,40 & 51,30 & 29,90 & 93,50 \\
\hline $\mathbf{U}$ & 3,20 & 3,20 & 3,14 & 4,23 & 4,23 & 5,20 & 2,94 & 8,72 & 2,88 & 6,67 & 5,60 \\
\hline $\mathbf{Y}$ & 6,00 & 7,00 & 5,00 & 10,00 & 11,00 & 6,00 & 7,10 & 30,10 & 18,50 & 89,00 & 23,30 \\
\hline $\mathbf{Z r}$ & 148,00 & 134,00 & 151,00 & 236,00 & 237,00 & 225,00 & 137,00 & 169,00 & 333,00 & 255,00 & 209,00 \\
\hline $\mathrm{Ce}$ & 63,00 & 48,40 & 50,90 & 68,90 & 67,20 & 78,70 & 36,80 & 88,20 & 191,00 & 229,00 & 375,00 \\
\hline Dy & 2,08 & 1,92 & 1,20 & 1,94 & 1,97 & 1,03 & 1,41 & 5,35 & 3,77 & 12,50 & 7,13 \\
\hline Er & 0,76 & 0,70 & 0,31 & 0,96 & 0,91 & 0,38 & 0,56 & 3,07 & 1,66 & 6,44 & 1,86 \\
\hline
\end{tabular}




\begin{tabular}{|c|c|c|c|c|c|c|c|c|c|c|c|}
\hline Eu & 0,45 & 0,31 & 0,35 & 0,89 & 0,91 & 0,76 & 0,45 & 0,83 & 1,34 & 3,31 & 6,00 \\
\hline Gd & 2,98 & 2,63 & 2,37 & 2,76 & 2,43 & 1,71 & 2,60 & 5,71 & 8,04 & 18,20 & 18,30 \\
\hline Ho & 0,27 & 0,27 & 0,15 & 0,36 & 0,29 & 0,14 & 0,22 & 1,06 & 0,64 & 2,40 & 0,96 \\
\hline $\mathbf{L a}$ & 35,60 & 27,00 & 27,90 & 39,80 & 39,60 & 49,40 & 19,10 & 43,20 & 101,00 & 149,00 & 189,00 \\
\hline $\mathbf{L u}$ & 0,07 & 0,05 & 0,05 & 0,06 & 0,07 & 0,19 & $<0,05$ & 0,43 & 0,23 & 0,68 & 0,15 \\
\hline Nd & 25,60 & 20,70 & 20,20 & 27,10 & 26,50 & 25,10 & 14,80 & 32,60 & 69,60 & 106,00 & 159,00 \\
\hline Sm & 4,70 & 4,00 & 3,50 & 3,90 & 3,90 & 3,00 & 3,50 & 7,10 & 11,90 & 20,40 & 28,60 \\
\hline $\mathbf{T b}$ & 0,37 & 0,33 & 0,27 & 0,33 & 0,26 & 0,19 & 0,33 & 0,99 & 1,02 & 2,63 & 2,19 \\
\hline $\mathbf{Y b}$ & 0,70 & 0,60 & 0,30 & 0,90 & 0,90 & 0,40 & 0,40 & 2,90 & 1,60 & 4,80 & 1,30 \\
\hline
\end{tabular}


Table 6

\begin{tabular}{|c|c|c|c|c|c|c|c|c|}
\hline Sample & F-05 & F-22 & F-22A & F-22 B & F-22 C & F-20 & G-4 & G-13 \\
\hline $\begin{array}{c}\text { General } \\
\text { classification }\end{array}$ & Granodiorite & Granodiorite & Granodiorite & Granodiorite & Granodiorite & Granodiorite & Granodiorite & Granodiorite \\
\hline $\mathrm{SiO}_{2}$ & 72,5 & 71,7 & 70,8 & 72,3 & 72,6 & 73,5 & 71,6 & 70,2 \\
\hline $\mathrm{TiO}_{2}$ & 0,11 & 0,11 & 0,11 & 0,12 & 0,12 & 0,03 & 0,09 & 0,11 \\
\hline $\mathrm{Al}_{2} \mathrm{O}_{3}$ & 16,1 & 15,9 & 15,8 & 16,2 & 16,3 & 13,9 & 16,2 & 16,1 \\
\hline $\mathrm{FeO}$ & 0,18 & 0,22 & 0,19 & 0,22 & 0,2 & 0,32 & 0,35 & 0,44 \\
\hline $\mathrm{Fe}_{2} \mathrm{O}_{3}$ & 1,2 & 1,22 & 1,24 & 1,18 & 1,22 & 1,5 & 1,63 & 2,21 \\
\hline $\mathrm{MnO}$ & 0,02 & 0,03 & 0,1 & 0,2 & 0,1 & 0,04 & 0,04 & 0,04 \\
\hline MgO & 0,51 & 0,56 & 0,55 & 0,53 & 0,51 & 0 & 0,29 & 0,38 \\
\hline $\mathrm{CaO}$ & 2,75 & 2,75 & 2,77 & 2,76 & 2,75 & 1,34 & 2,65 & 2,79 \\
\hline $\mathrm{Na}_{2} \mathrm{O}$ & 4,2 & 4,2 & 4,2 & 4,2 & 4,1 & 3,53 & 4,74 & 4,68 \\
\hline $\mathrm{K}_{2} \mathrm{O}$ & 3,2 & 2,4 & 2,8 & 2,5 & 3 & 4,89 & 3 & 3,17 \\
\hline $\mathbf{P}_{2} \mathrm{O}_{5}$ & 0,02 & $<0.01$ & $<0.01$ & $<0.01$ & $<0.01$ & 0,074 & 0,028 & 0,045 \\
\hline LOI & 0,02 & 0,2 & 0,13 & 0,02 & 0,01 & 0,08 & $<0,01$ & $<0,01$ \\
\hline $\mathrm{SiO}_{2}$ & 100,81 & 99,29 & 98,69 & 100,23 & 100,91 & 99,204 & 100,618 & 100,165 \\
\hline & & & & & 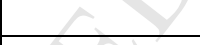 & & & \\
\hline $\mathbf{B a}$ & 1460 & 951 & 1290 & 1345 & 1090 & 1449 & 1095 & 1502 \\
\hline $\mathbf{F}$ & 182 & 236 & 189 & 199 & 219 & 30 & 347 & 448 \\
\hline $\mathbf{G a}$ & 20 & 20 & 21 & 22 & 19 & 14 & 21 & 20 \\
\hline Hf & 8 & 9 & 6 & 5 & 8 & 9 & 6 & 7 \\
\hline $\mathrm{Nb}$ & 6 & 5 & 6 & 7 & 5 & 9 & 18 & 14 \\
\hline $\mathbf{R b}$ & 120 & 80 & 92 & 95 & 89 & 117 & 51 & 58 \\
\hline $\mathbf{S r}$ & 830 & 748 & 789 & $\begin{array}{r}800 \\
\end{array}$ & 799 & 343 & 762 & 766 \\
\hline $\mathbf{T a}$ & 0,45 & 0,56 & 0,43 & 0,5 & 0,54 & 0,65 & 0,55 & 0,44 \\
\hline Th & 22 & 2,2 & 3,2 & 6,4 & 12 & 4 & 3,4 & 3,5 \\
\hline $\mathbf{U}$ & 8,5 & 4,8 & 4,9 & 5,9 & 8,5 & 4.5 & 4,5 & 4,6 \\
\hline $\mathbf{Y}$ & 6,1 & 7,7 & 6,2 & 7,4 & 6,2 & 18 & 14 & 17 \\
\hline $\mathbf{Z r}$ & 129 & 94 & 99 & 103 & 111 & 49 & 177 & 179 \\
\hline
\end{tabular}




\begin{tabular}{|c|c|c|c|c|c|c|c|c|}
$\mathbf{C e}$ & 24,9 & 23,1 & 23,2 & 23,6 & 24,6 & 17,1 & 17,9 & 17,9 \\
\hline $\mathbf{D y}$ & 1,05 & 0,93 & 0,95 & 0,93 & 0,98 & 1,04 & 0,58 & 0,61 \\
\hline $\mathbf{E r}$ & 0,5 & 0,51 & 0,5 & 0,52 & 0,5 & 0,74 & 0,32 & 0,3 \\
\hline $\mathbf{E u}$ & 0,36 & 0,41 & 0,41 & 0,38 & 0,4 & 0,4 & 0,35 & 0,31 \\
\hline $\mathbf{G d}$ & 1,48 & 1,44 & 1,44 & 1,47 & 1,46 & 1,05 & 0,99 & 1,1 \\
\hline $\mathbf{H o}$ & 0,19 & 0,19 & 0,2 & 0,18 & 0,19 & 0,23 & 0,12 & 0,11 \\
\hline $\mathbf{L a}$ & 14,6 & 17,2 & 15,4 & 16,8 & 14,5 & 14,5 & 10,2 & 12,6 \\
\hline $\mathbf{L u}$ & 0,06 & 0,05 & 0,06 & 0,06 & 0,07 & 0,15 & 0,05 & 0,05 \\
\hline $\mathbf{N d}$ & 9,5 & 8,7 & 8,7 & 9,2 & 8,8 & 6,8 & 6 & 7,6 \\
\hline $\mathbf{P r}$ & 3,15 & 2,92 & 2,88 & 2,87 & 2,89 & 2,13 & 1,85 & 2,16 \\
\hline $\mathbf{S m}$ & 1,8 & 1,9 & 1,9 & 1,9 & 1,9 & 1,2 & 1,1 & 1,3 \\
\hline $\mathbf{T b}$ & 0,22 & 0,2 & 0,21 & 0,2 & 0,2 & 0,16 & 0,11 & 0,12 \\
\hline Tm & 0,07 & 0,07 & 0,07 & 0,08 & 0,07 & 0,14 & 0,05 & 0,05 \\
\hline
\end{tabular}


Table 7

\begin{tabular}{|c|c|c|c|c|c|c|c|}
\hline ID & TB-01 & TB-02 & TB-03 & TB-04 & TB-05 & TB-06 & TB-07 \\
\hline $\begin{array}{c}\text { General } \\
\text { classification }\end{array}$ & Granodiorite & Granodiorite & Granodiorite & Granodiorite & Granodiorite & Granodiorite & Granodiorite \\
\hline $\mathrm{SiO}_{2}$ & 74,40 & \begin{tabular}{|l|}
68,80 \\
\end{tabular} & \begin{tabular}{|l|}
66,00 \\
\end{tabular} & \begin{tabular}{|l|}
69,20 \\
\end{tabular} & \begin{tabular}{|l|}
72,10 \\
\end{tabular} & \begin{tabular}{|l|}
53,7 \\
\end{tabular} & 54,1 \\
\hline $\mathrm{TiO}_{2}$ & 0,04 & 0,43 & 0,35 & 0,04 & 0,04 & 0,97 & 0,95 \\
\hline $\mathrm{Al}_{2} \mathrm{O}_{3}$ & 14,50 & 15,50 & 16,40 & 16,50 & 15,50 & 15,7 & 15,7 \\
\hline $\mathrm{FeO}$ & 0,78 & 3,05 & 2,36 & 3,10 & 0,79 & 10,85 & 11,21 \\
\hline $\mathrm{Fe}_{2} \mathrm{O}_{3}$ & 1,31 & 4,08 & 7,20 & 4,20 & 2,24 & 16,6 & 16,6 \\
\hline MnO & 0,02 & 0,04 & 0,15 & 0,02 & 0,01 & 0,28 & 0,27 \\
\hline MgO & 0,24 & 1,06 & 2,01 & 1,08 & 0,25 & 4,28 & 4,22 \\
\hline $\mathrm{CaO}$ & 1,54 & 2,67 & 1,94 & 2,55 & 1,66 & 1,82 & 1,86 \\
\hline $\mathrm{Na}_{2} \mathrm{O}$ & 4,13 & 4,81 & 3,14 & 4,50 & 4,12 & 2,68 & 2,65 \\
\hline $\mathrm{K}_{2} \mathrm{O}$ & 4,01 & 2,15 & 2,86 & 2,40 & 4,04 & 3,5 & 3,46 \\
\hline $\mathbf{P}_{2} \mathrm{O}_{5}$ & 0,04 & 0,12 & 0,04 & 0,02 & 0,04 & 0,065 & 0,069 \\
\hline LOI & 0,20 & 0,10 & 0,20 & 0,23 & 0,22 & 0,49 & 0,45 \\
\hline Total & 100,43 & 99,76 & 100,29 & 100,74 & 100,22 & 100,09 & 100,33 \\
\hline & & & & X & ) & & \\
\hline Ba & 195,00 & 1319,00 & 497,00 & 1322,00 & 212,00 & 463 & 427 \\
\hline $\mathbf{F}$ & 112,00 & 480,00 & 368,00 & 487,00 & 112,00 & 945 & 934 \\
\hline Ga & 25,00 & 21,00 & 22,00 & 22,00 & 22,00 & 19 & 20 \\
\hline Hf & 6,10 & 3,40 & 6,40 & 6,40 & 6,40 & 7 & 7 \\
\hline $\mathrm{Nb}$ & 19,00 & 6,00 & 20,00 & 6,00 & 22,00 & 23 & 30 \\
\hline $\mathbf{R b}$ & 128,00 & 78,00 & 81,00 & 77,00 & 144,00 & 127 & 132 \\
\hline $\mathrm{Sr}$ & 131,00 & 704,00 & 208,00 & 704,00 & 132,00 & 140 & 156 \\
\hline Ta & 12,00 & 13,00 & 10,00 & 12,00 & 12,00 & 9 & 9 \\
\hline Th & 13,00 & 9,00 & 3,00 & 10,00 & 10,00 & 4 & 3 \\
\hline $\mathbf{U}$ & 6,50 & 6,30 & 7,50 & 5,60 & 6,40 & 5 & 7 \\
\hline $\mathbf{Y}$ & 29,00 & $<3$ & 82,00 & 4,00 & 29,00 & 31 & 30 \\
\hline $\mathbf{Z r}$ & 33,00 & 220,00 & 148,00 & 221,00 & 32,00 & 100 & 101 \\
\hline & & 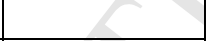 & & & & & \\
\hline $\mathrm{Ce}$ & 53,50 & 74,20 & 43,30 & 70,30 & 55,20 & 67,90 & 58,00 \\
\hline Dy & 3,22 & 1,20 & 3,33 & 1,20 & 3,22 & 5,98 & 4,70 \\
\hline $\mathbf{E r}$ & 2,00 & 0,42 & 2,20 & 0,44 & 2,00 & 2,96 & 2,52 \\
\hline Eu & 0,49 & 0,76 & 0,50 & 0,65 & 0,50 & 1,53 & $1 \mathrm{~m} 38$ \\
\hline Gd & 3,22 & 1,78 & 3,24 & 1,55 & 3,33 & 6,10 & 4,85 \\
\hline Ho & 0,64 & 0,19 & 0,66 & 0,20 & 0,55 & 1,28 & 1,02 \\
\hline $\mathbf{L a}$ & 37,00 & 46,10 & 31,70 & 46,30 & 38,00 & 43,40 & 36,10 \\
\hline Lu & 0,08 & 0,05 & 0,06 & 0,07 & 0,09 & 0,64 & 0,46 \\
\hline Nd & 17,50 & 22,80 & 14,40 & 23,10 & 18,30 & 31,10 & 25,80 \\
\hline $\mathrm{Pr}$ & 5,63 & 7,39 & 4,51 & 7,41 & 5,93 & 8,68 & 7,13 \\
\hline $\mathrm{Sm}$ & 3,10 & 2,90 & 2,90 & 3,10 & 3,20 & 6,20 & 4,70 \\
\hline $\mathbf{T b}$ & 0,44 & 0,18 & 1,1 & 0,12 & 0,55 & 1,18 & 0,89 \\
\hline $\mathrm{Tm}$ & 0,32 & 0,07 & 0.8 & 0,44 & 0,08 & 0,63 & 0,50 \\
\hline $\mathbf{Y b}$ & 2,1 & 0,4 & 2,2 & 2,10 & 2,20 & 2,90 & 2,50 \\
\hline
\end{tabular}


Table 8

\begin{tabular}{|c|c|c|c|c|c|c|c|c|c|c|}
\hline Data set/Group & \multicolumn{2}{|c|}{ G1 } & \multicolumn{2}{|c|}{ G2a } & \multicolumn{2}{|c|}{ G2b } & \multicolumn{2}{|c|}{ G2c } & \multicolumn{2}{|c|}{ G2d } \\
\hline Age U-Pb (Ma) & \multicolumn{2}{|c|}{$2324 \pm 6-2.091 \pm 6.6$} & \multicolumn{2}{|c|}{$2054-6 /+8-2041 \pm 23$} & \multicolumn{2}{|c|}{$2066 \pm 37-2019 \pm 32$} & \multicolumn{2}{|c|}{$2058 \pm 8-1852 \pm 50$} & \multicolumn{2}{|c|}{$2049 \pm 12-1929 \pm 16$} \\
\hline $\mathrm{K}_{2} \mathrm{O}$ versus $\mathrm{SiO} 2$ & \multicolumn{2}{|c|}{$\begin{array}{c}\text { Low-K . Medium-K. } \\
\text { High-K }\end{array}$} & \multicolumn{2}{|c|}{ High-K } & \multicolumn{2}{|c|}{ High-K } & \multicolumn{2}{|c|}{ Medium-K. High-K } & \multicolumn{2}{|c|}{ Medium-K. High-K } \\
\hline Plag. Comp & \multicolumn{2}{|c|}{$\begin{array}{l}\text { Oligoclase (An 22- } \\
29 \%)\end{array}$} & \multicolumn{2}{|c|}{ Oligoclase (An 20-30\%) } & \multicolumn{2}{|c|}{$\begin{array}{l}\text { Albite to oligoclase } \\
\text { (An 06-30\%) }\end{array}$} & \multicolumn{2}{|c|}{ oligoclase to albite (An 8-29\%) } & \multicolumn{2}{|c|}{ oligoclase to albite (An 8-28\%) } \\
\hline Element & $\mathrm{M}$ & SD & $\mathrm{M}$ & $\mathrm{SD}$ & $\mathrm{M}$ & SD & $\mathrm{M}$ & SD & $\mathrm{M}$ & SD \\
\hline $\mathrm{SiO}_{2}$ & 70.77 & 3.30 & 61.67 & 5.79 & 69.30 & 6.26 & 74.76 & 1.68 & 72.30 & 2.57 \\
\hline $\mathrm{TiO}_{2}$ & 0.34 & 0.22 & 0.93 & 0.45 & 0.82 & 2.30 & 0.13 & 0.12 & 0.21 & 0.12 \\
\hline $\mathrm{Al}_{2} \mathrm{O}_{3}$ & 14.74 & 1.26 & 15.35 & 1.85 & 14.02 & 1.50 & 13.35 & 1.37 & 14.48 & 0.85 \\
\hline $\mathrm{FeO}$ & 2.45 & 1.17 & 2.55 & 1.51 & 2.16 & 1.43 & 1.18 & 0.65 & 1.24 & 0.84 \\
\hline $\mathrm{Fe}_{2} \mathrm{O}_{3}$ & 2.16 & 2.10 & 3.08 & 1.15 & 3.45 & 2.79 & 2.00 & 0.97 & 2.26 & 1.40 \\
\hline MnO & 0.06 & 0.03 & 0.12 & 0.04 & 0.05 & 0.04 & 0.04 & 0.04 & 0.04 & 0.03 \\
\hline MgO & 0.69 & 0.44 & 2.15 & 1.51 & 0.91 & 1.19 & 0.22 & 0.16 & 0.60 & 0.54 \\
\hline $\mathrm{CaO}$ & 2.12 & 1.08 & 3.32 & 1.44 & 1.87 & 1.51 & 0.93 & 0.41 & 1.34 & 0.72 \\
\hline $\mathrm{Na}_{2} \mathrm{O}$ & 3.57 & 0.88 & 2.99 & 0.60 & 3.37 & 0.96 & 3.72 & 0.83 & 4.02 & 0.59 \\
\hline $\mathrm{K}_{2} \mathrm{O}$ & 3.96 & 1.17 & 6.07 & 1.57 & 4.90 & 1.18 & 4.76 & 0.93 & 4.30 & 1.26 \\
\hline $\mathbf{P}_{2} \mathbf{O}_{5}$ & 0.14 & 0.09 & 0.43 & 0.28 & 0.19 & 0.27 & 0.06 & 0.05 & 0.11 & 0.10 \\
\hline Normative corundum & 2.9 & 2.32 & 0.39 & 0.92 & 1.06 & 1.58 & 0.72 & 0.67 & 1.57 & 1.68 \\
\hline & & & & 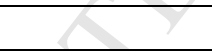 & & & & & & \\
\hline $\mathbf{R b}$ & 135.38 & 75.43 & 190.58 & 112.88 & 198.04 & 88.11 & 254.78 & 191.88 & 163.97 & 71.64 \\
\hline $\mathbf{S r}$ & 360.30 & 284.05 & 1018.48 & 925.25 & 316.86 & 446.10 & 94.97 & 102.48 & 266.08 & 241.86 \\
\hline $\mathbf{B a}$ & 1175.98 & 572.49 & 2418.18 & 4399.37 & 917.05 & 711.31 & 383.19 & 346.43 & 496.59 & 312.87 \\
\hline Ga & 21.00 & 3.68 & 35.00 & 1.02 & 19.97 & 2.46 & 25.68 & 6.79 & 21.26 & 2.66 \\
\hline Cs & 9.73 & 12.54 & 7.82 & 6.53 & 8.44 & 15.60 & 6.00 & 3.05 & 3.84 & 3.53 \\
\hline $\mathbf{N b}$ & 15.06 & 7.65 & 22.74 & 12.37 & 21.84 & 14.80 & 39.92 & 48.35 & 10.01 & 5.66 \\
\hline $\mathbf{Y}$ & 30.29 & 21.93 & 34.14 & 36.96 & 49.69 & 39.12 & 82.43 & 50.98 & 19.23 & 23.82 \\
\hline $\mathbf{Z r}$ & 259.03 & 192.39 & 490.66 & 264.77 & 293.22 & 241.86 & 181.20 & 136.37 & 166.04 & 98.81 \\
\hline Hf & 13.14 & 12.11 & 12.12 & 5.45 & 7.44 & 4.36 & 5.87 & 3.03 & 6.42 & 2.74 \\
\hline Ta & 4.21 & 6.98 & 5.07 & 0.35 & 5.21 & 7.17 & 4.98 & 7.23 & 4.33 & 4.23 \\
\hline Th & 31.69 & 30.07 & 32.38 & 43.57 & 52.98 & 31.32 & 29.79 & 19.36 & 30.62 & 32.53 \\
\hline
\end{tabular}




\begin{tabular}{|c|c|c|c|c|c|c|c|c|c|c|}
\hline $\mathbf{U}$ & 6.01 & 7.60 & 11.07 & 4.74 & 11.50 & 11.26 & 9.07 & 6.98 & 7.00 & 6.53 \\
\hline \multicolumn{11}{|l|}{$\mathrm{Cr}$} \\
\hline $\mathbf{F}$ & 426.46 & 313.57 & 0.26 & 0.22 & 353.76 & 152.50 & NI & NI & 311.80 & 188.40 \\
\hline La & 84.28 & 95.16 & 168.18 & 93.47 & 139.69 & 93.10 & 65.39 & 57.23 & 65.35 & 74.69 \\
\hline $\mathrm{Ce}$ & 143.62 & 150.86 & 346.31 & 179.32 & 256.93 & 154.68 & 111.53 & 95.00 & 100.96 & 100.97 \\
\hline Nd & 56.91 & 55.43 & 134.28 & 65.85 & 94.51 & 56.12 & 44.92 & 37.06 & 37.98 & 38.65 \\
\hline Sm & 9.11 & 7.77 & 18.82 & 8.90 & 16.04 & 8.85 & 9.60 & 7.13 & 6.03 & 5.86 \\
\hline Eu & 1.45 & 1.20 & 3.65 & 1.47 & 2.12 & 1.99 & 0.71 & 0.53 & 0.74 & 0.46 \\
\hline Gd & 6.30 & 5.65 & 10.88 & 5.18 & 12.15 & 7.54 & 9.37 & 8.01 & 4.00 & 3.85 \\
\hline $\mathbf{T b}$ & 0.84 & 0.74 & $\mathrm{NI}$ & $\mathrm{NI}$ & 2.86 & 1.13 & 2.19 & 0.87 & 1.13 & 1.00 \\
\hline Dy & 4.38 & 3.92 & 6.30 & 2.90 & 8.28 & 5.81 & 11.44 & 9.07 & 2.44 & 1.81 \\
\hline Ho & 0.79 & 0.73 & 1.12 & 0.55 & 1.52 & 1.16 & 2.91 & 1.84 & 0.47 & 0.36 \\
\hline Er & 2.08 & 1.96 & 2.52 & 1.27 & 3.98 & 3.22 & 7.33 & 6.32 & 1.08 & 0.82 \\
\hline $\mathbf{Y b}$ & 2.00 & 1.70 & 1.62 & 0.85 & 3.60 & 2.95 & 7.59 & 6.36 & 1.31 & 1.29 \\
\hline $\mathbf{L u}$ & 0.30 & 0.24 & 0.23 & 0.14 & 0.52 & 0.42 & 1.07 & 0.92 & 0.10 & 0.07 \\
\hline REE total & 335.60 & 315.75 & 693.90 & 349.45 & 547.38 & 315.28 & 263.98 & 219.38 & 244.77 & 250.73 \\
\hline $\mathbf{E u} / \mathbf{E u} \mathbf{u}^{*}$ & 0.62 & 0.22 & 0.82 & 0.46 & 0.44 & 0.30 & 0.32 & 0.13 & 0.57 & 0.25 \\
\hline LaN/YbN & 33.90 & 30.91 & 80.08 & 43.78 & 40.05 & 18.28 & 5.42 & 4.12 & 42.44 & 33.48 \\
\hline CeN/YbN & 21.57 & 16.34 & 63.72 & 34.23 & 28.70 & 11.15 & 3.61 & 2.63 & 28.40 & 22.94 \\
\hline A/NK & 1.47 & 0.19 & 1.42 & 0.10 & 1.30 & 0.16 & 1.19 & 0.08 & 1.30 & 0.16 \\
\hline A/CNK & 1.06 & 0.09 & 0.89 & 0.13 & 1.00 & 0.14 & 1.03 & 0.04 & 1.06 & 0.09 \\
\hline $\mathrm{K} 20 / \mathrm{Na} 2 \mathrm{O}$ & 1.23 & 0.58 & 2.32 & 2.05 & 1.61 & 0.60 & 1.38 & 0.49 & 1.13 & 0.53 \\
\hline$(\mathrm{Na}+\mathrm{K}) / \mathrm{Al}$ & 0.54 & 0.07 & 0.49 & 0.06 & 0.48 & 0.06 & 0.44 & 0.03 & 0.48 & 0.06 \\
\hline $\mathrm{Mg} /(\mathrm{Fe}+\mathrm{Mg})$ & 0.36 & 0.13 & 0.58 & 0.14 & 0.30 & 0.13 & 0.17 & 0.12 & 0.28 & 0.12 \\
\hline $\mathrm{Fe} /(\mathrm{Fe}+\mathrm{Mg})$ & 0.64 & 0.13 & 0.42 & 0.14 & 0.70 & 0.13 & 32.72 & 0.12 & 0.72 & 0.12 \\
\hline
\end{tabular}




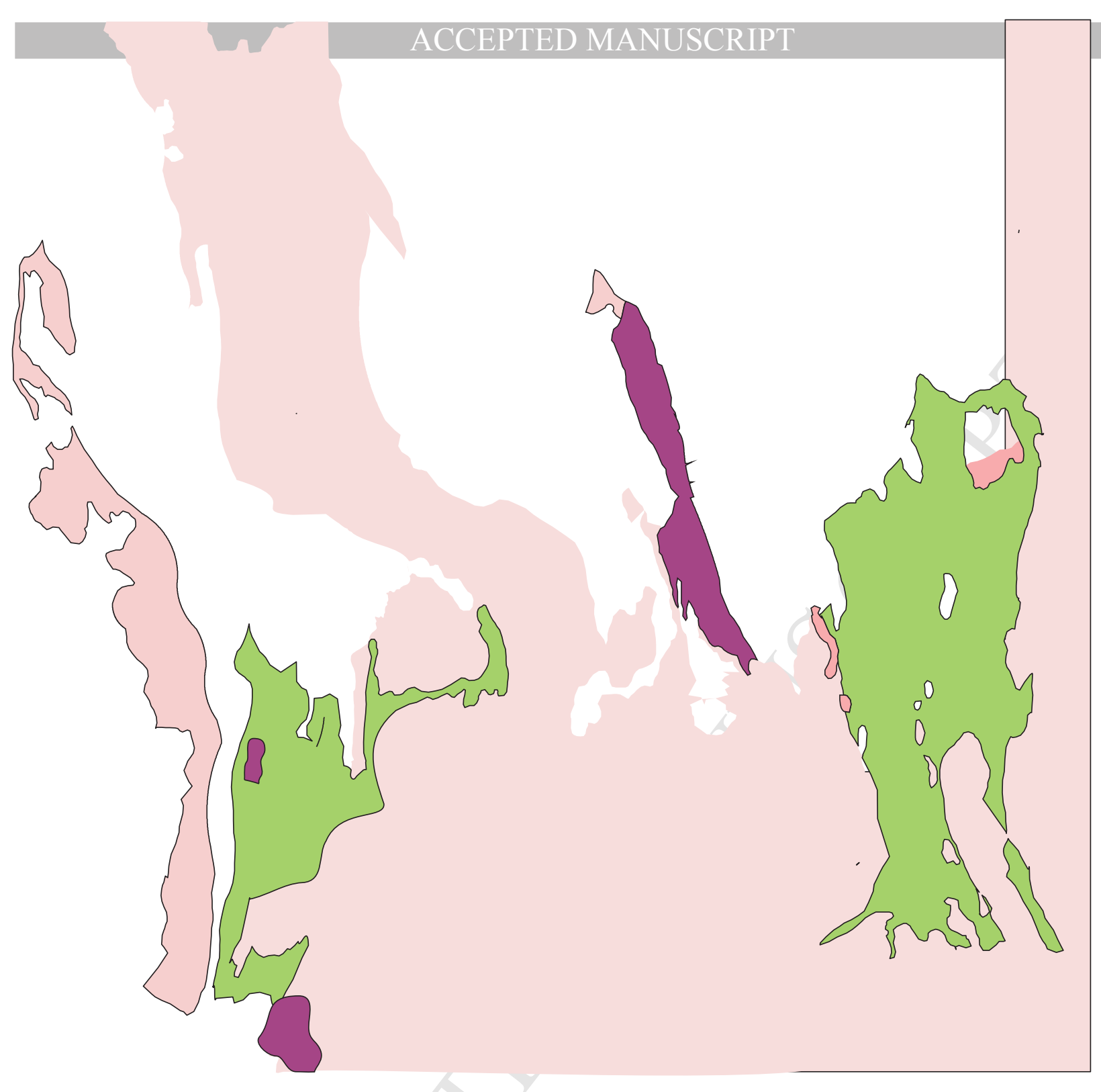

Staterian to Tonian metavolcanosedimentary sequences and Staterian Lagoa Real suite

\section{SIDERIAN-OROSIRIAN GRANITOIDS}

\section{Group 1}

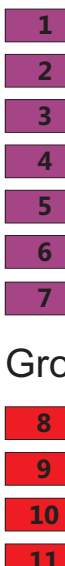

Veredinha

Ibitiara-Queimada Nova

Aracatu

Lagoa das Almas

Humaitá

Rio do Paulo

Jussiape I

Group 2a

\begin{tabular}{l}
\hline 8 \\
\hline 10 \\
\hline 11 \\
\hline 12
\end{tabular}

Estreito

Ceraíma

Cara Suja

Guanambi-Urandi Multiple intrusion

Boquira Granitoid

\section{Group 2b}

13 Caculé

14 Jussiape II

15 Santa Isabel

Group 2c

16 Pé do Morro

17 Riacho das Pedras

18 Serra da Franga

\section{Group 2d}

$+20+$ Umburanas

$+21+$ Mariana

$+22+$ Espírito Santo

+23+ Lagoa Grande-Lagoinha

$+24+$ Gameleira

+25+ Caetano-Aliança

$+26+$ Campo do Meio

$+27+$ Broco

$+28+$ Piripá

\section{ARCHEAN/PALEOPROTEROZOIC UNITS}

TTGs, gneisses, mafic intrusions,

migmatites and granulites

Metavolcanosedimentaries sequences 
a)

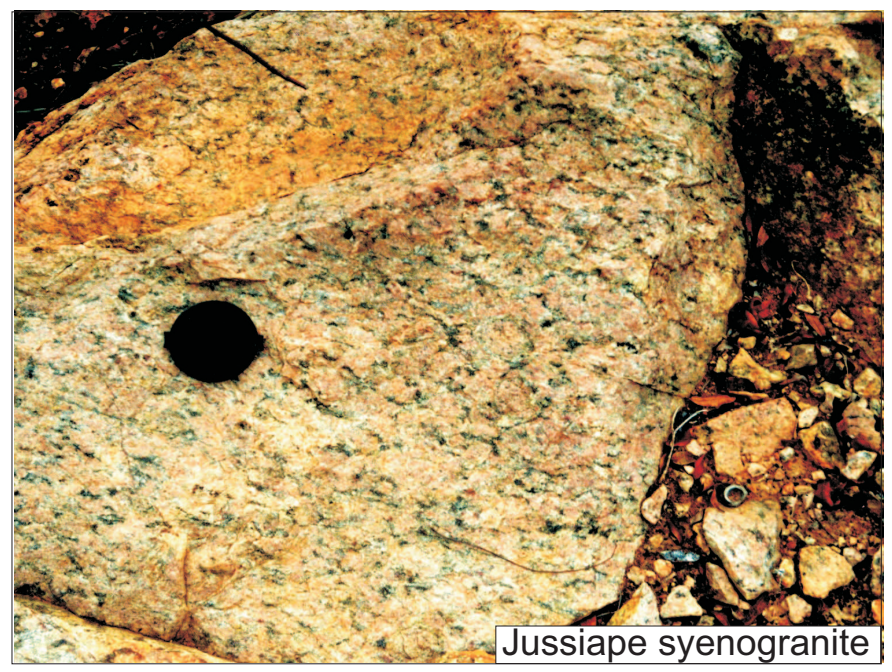

c)

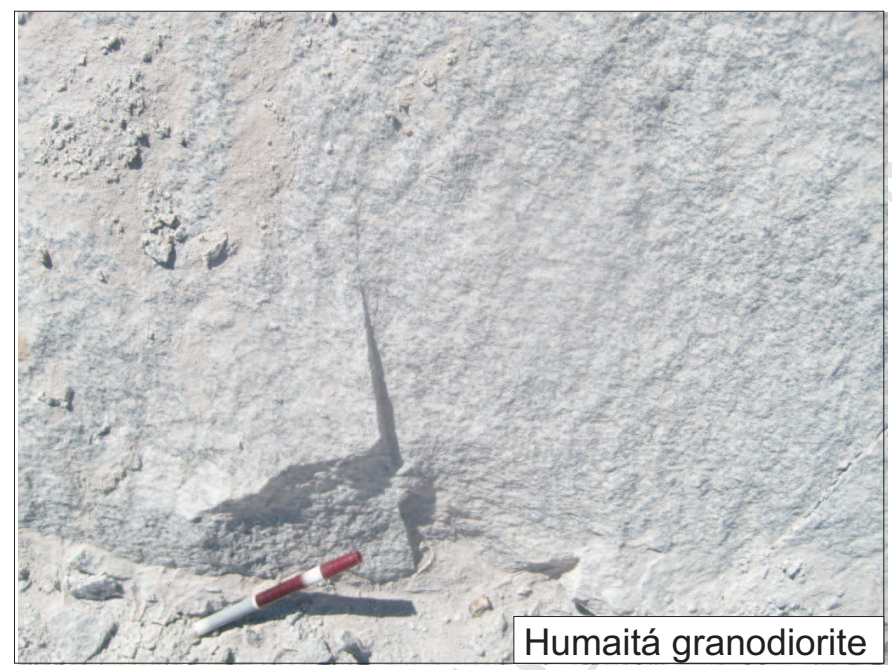

b)

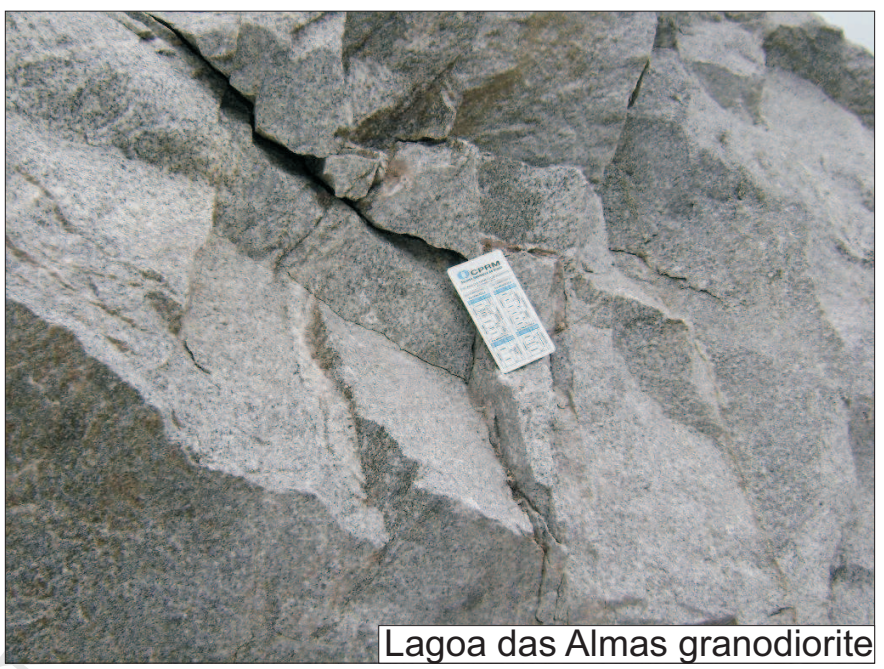

d)

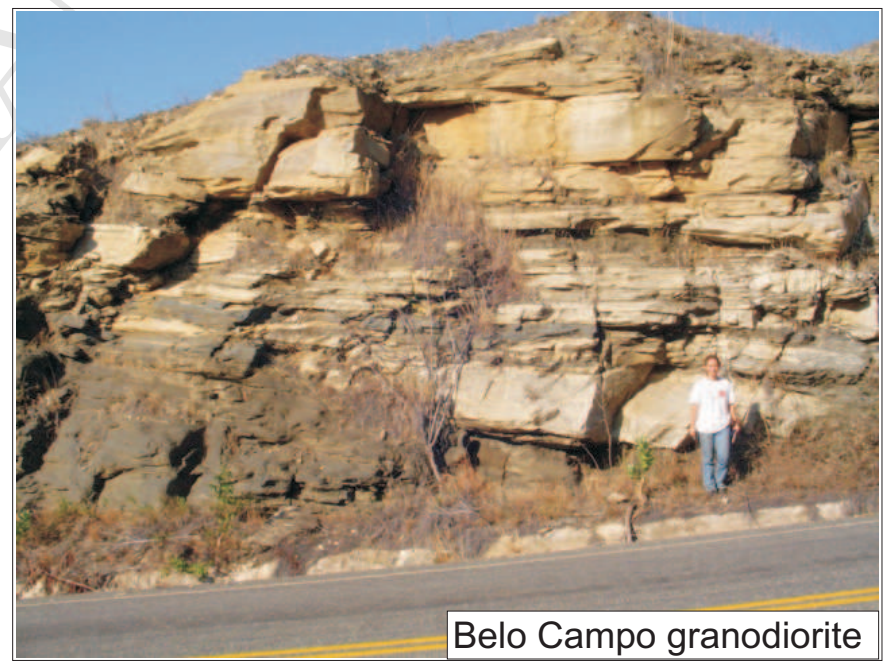

e)

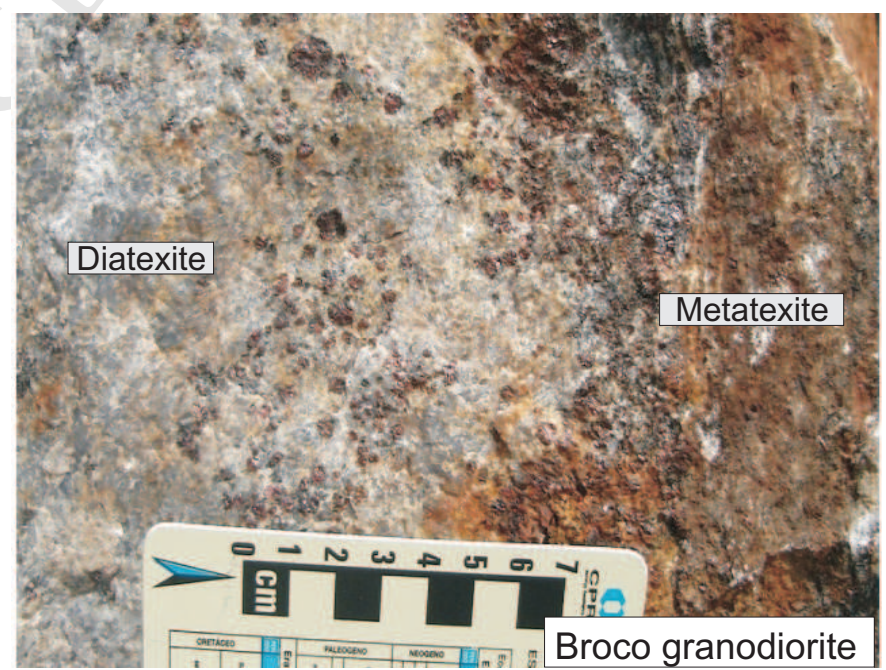

Figure 3 

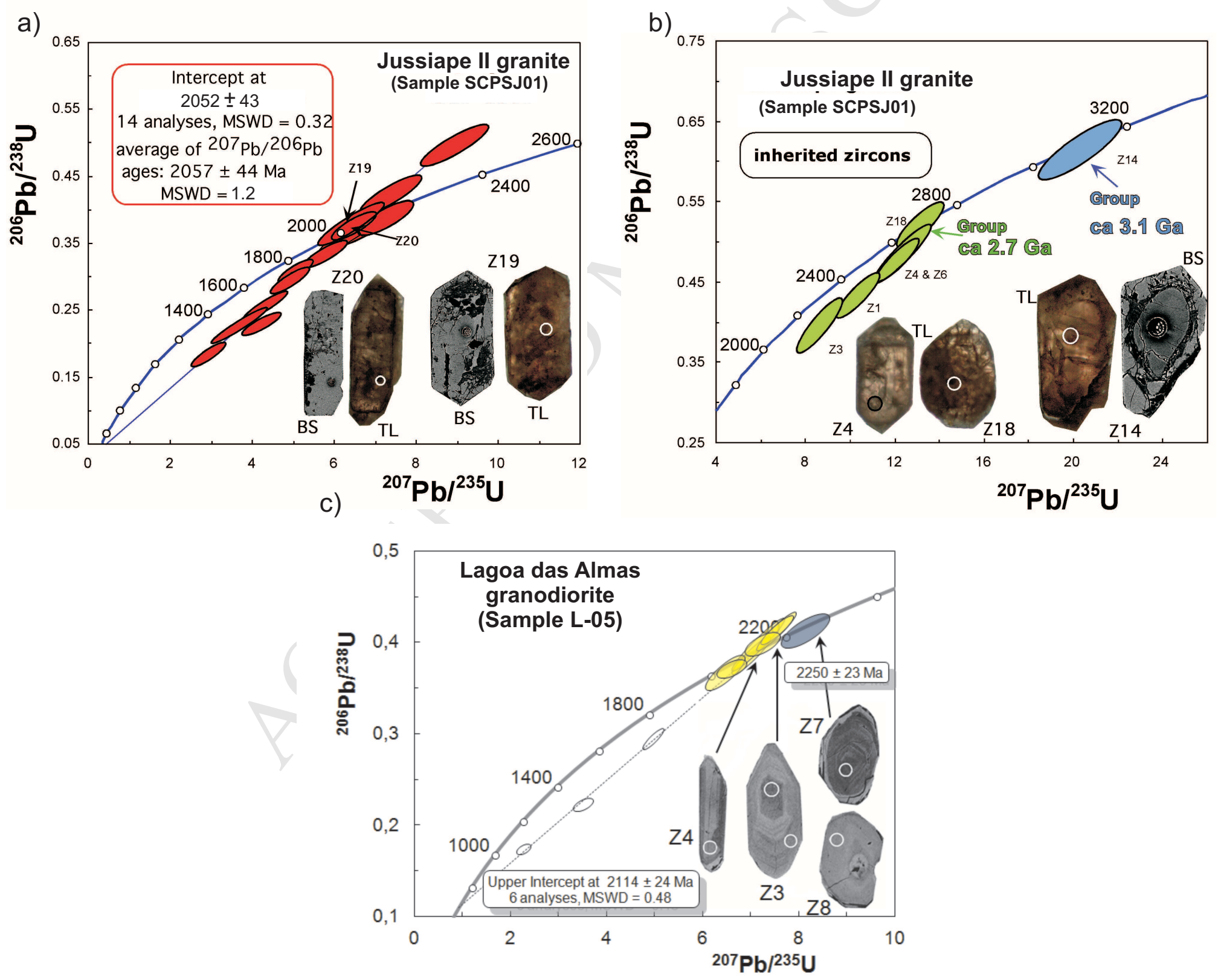


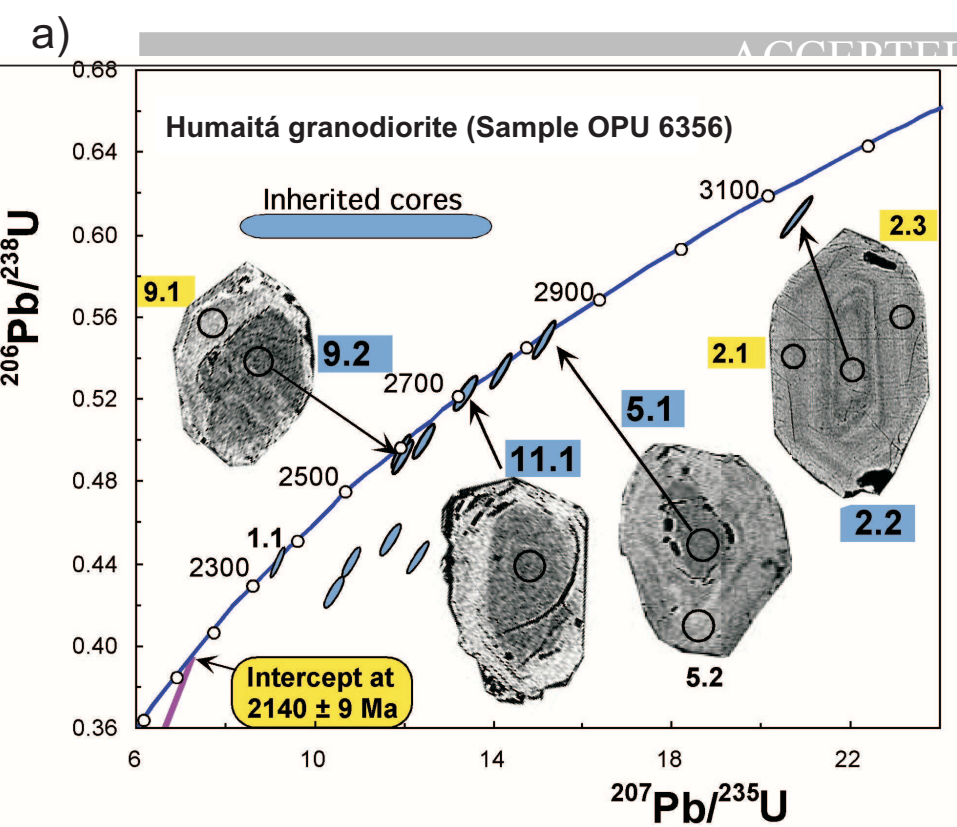

b)

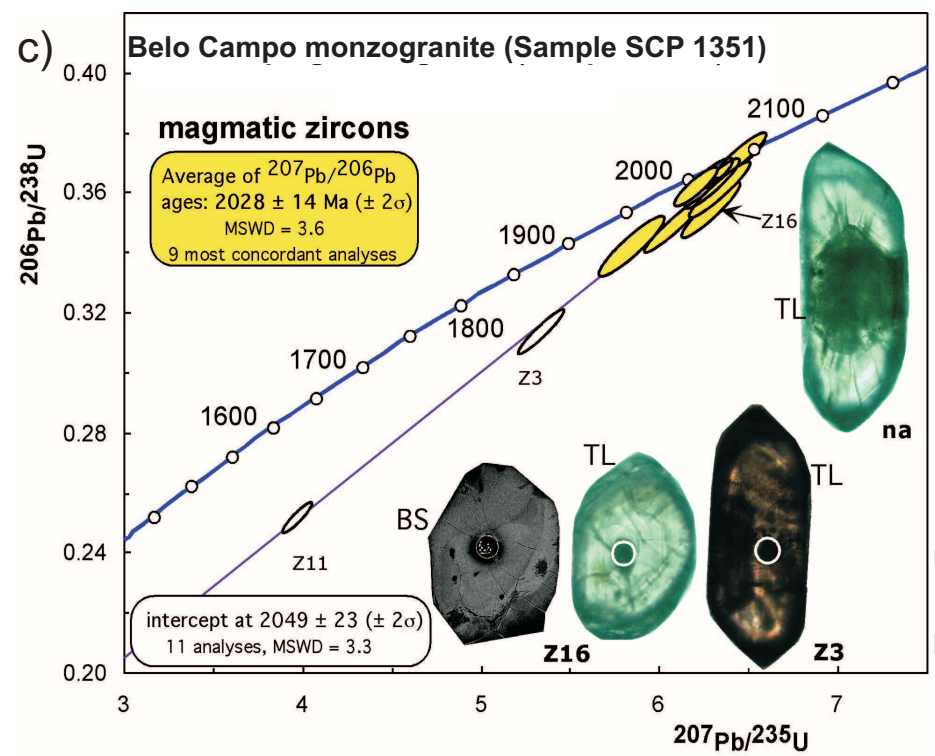

e)
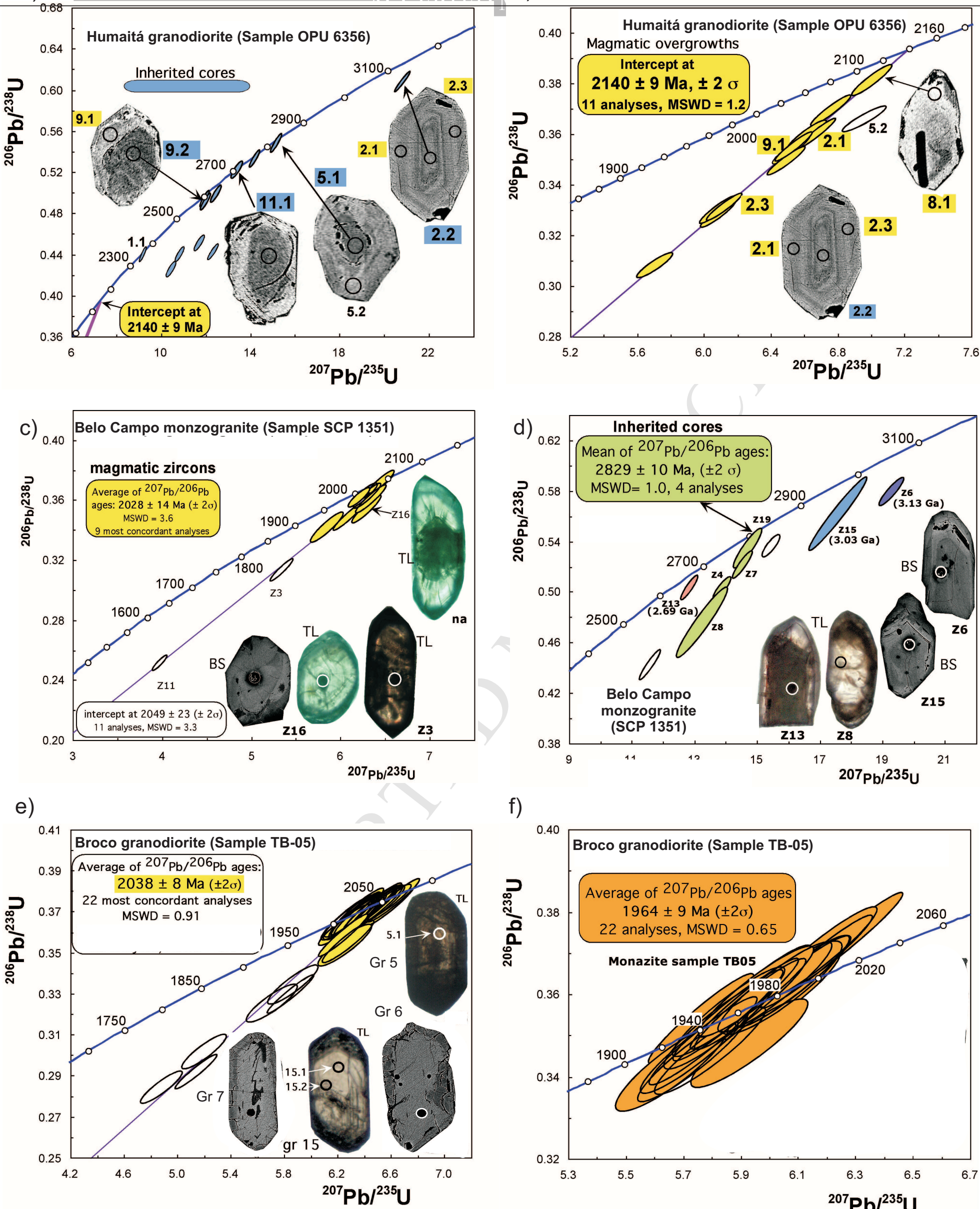

f)

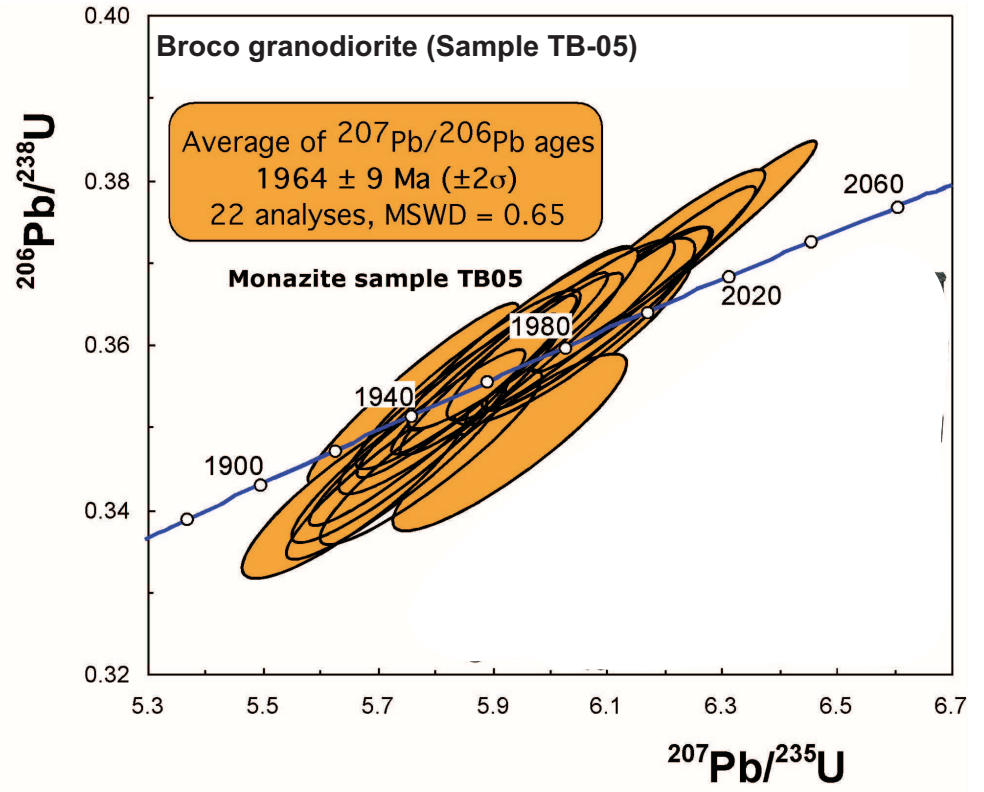




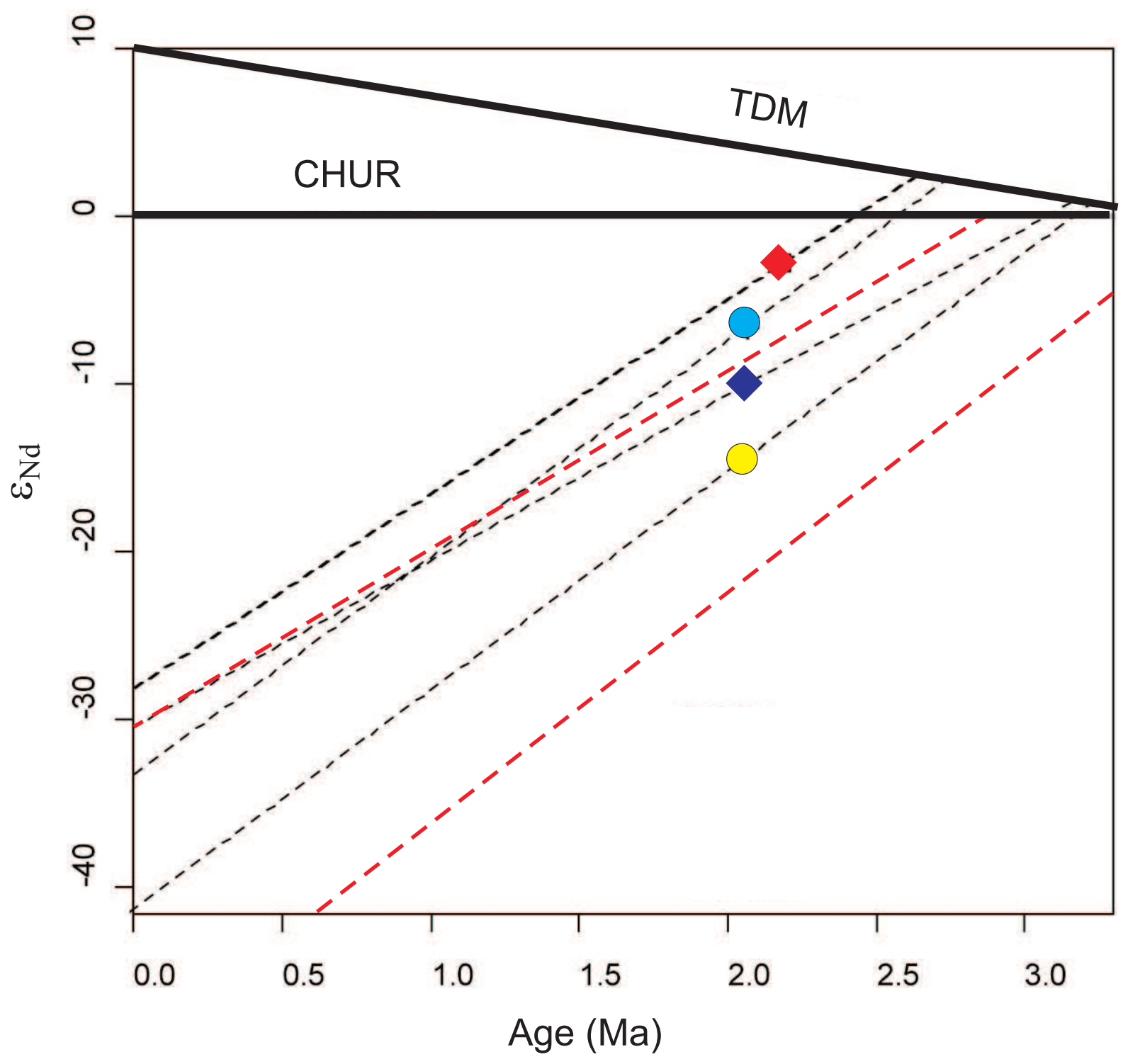

$\downarrow$ Jussiape $\diamond$ Humaitá $\bigcirc$ Belo Campo $\bigcirc$ Broco

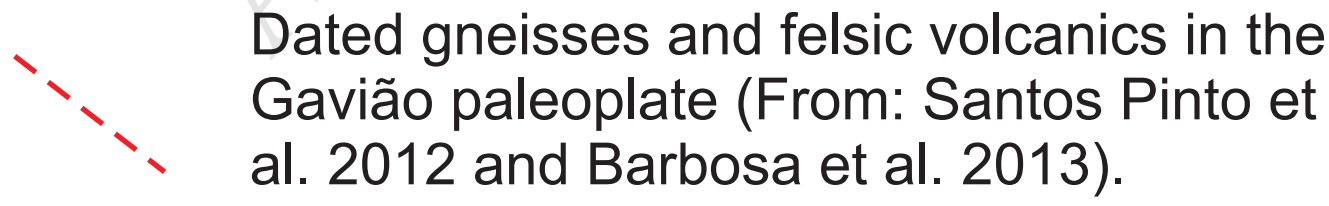


a) b)
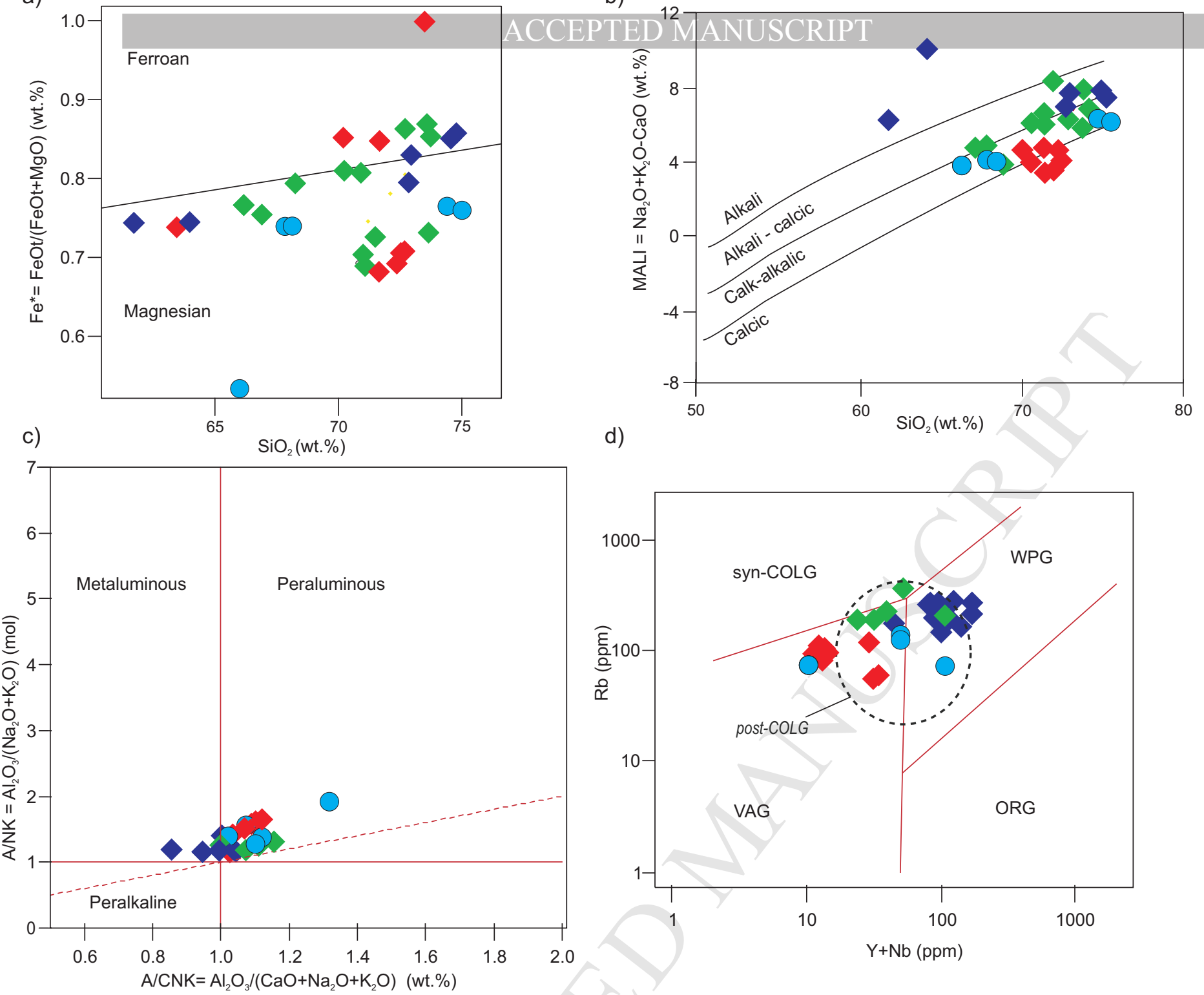

e)

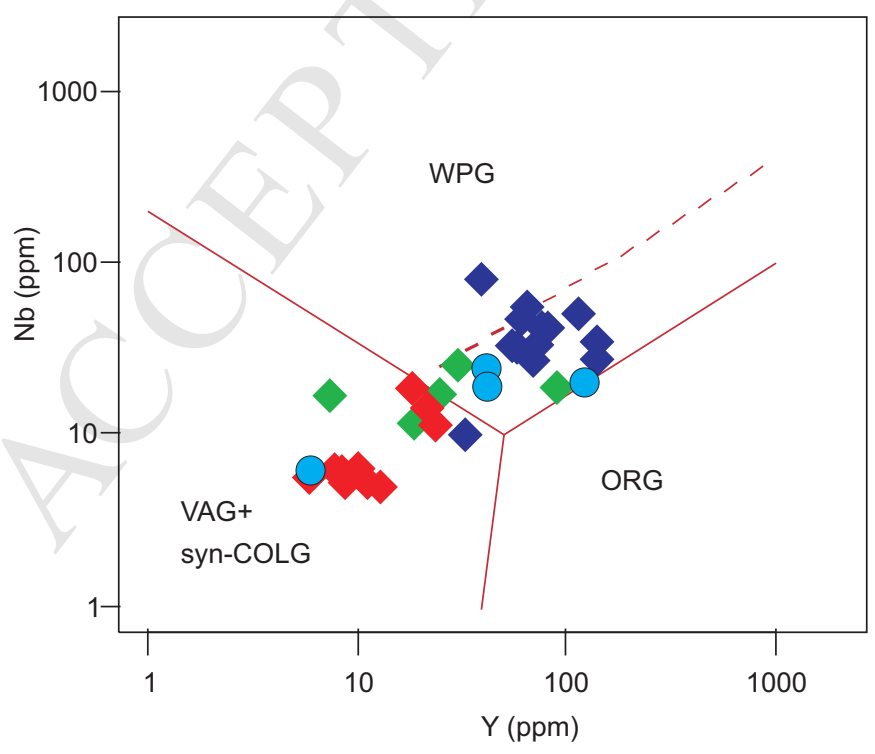

Humaitá $\diamond$ Lagoa das Almas $\diamond$ Jussiape Broco 
a) $£$

b) 8
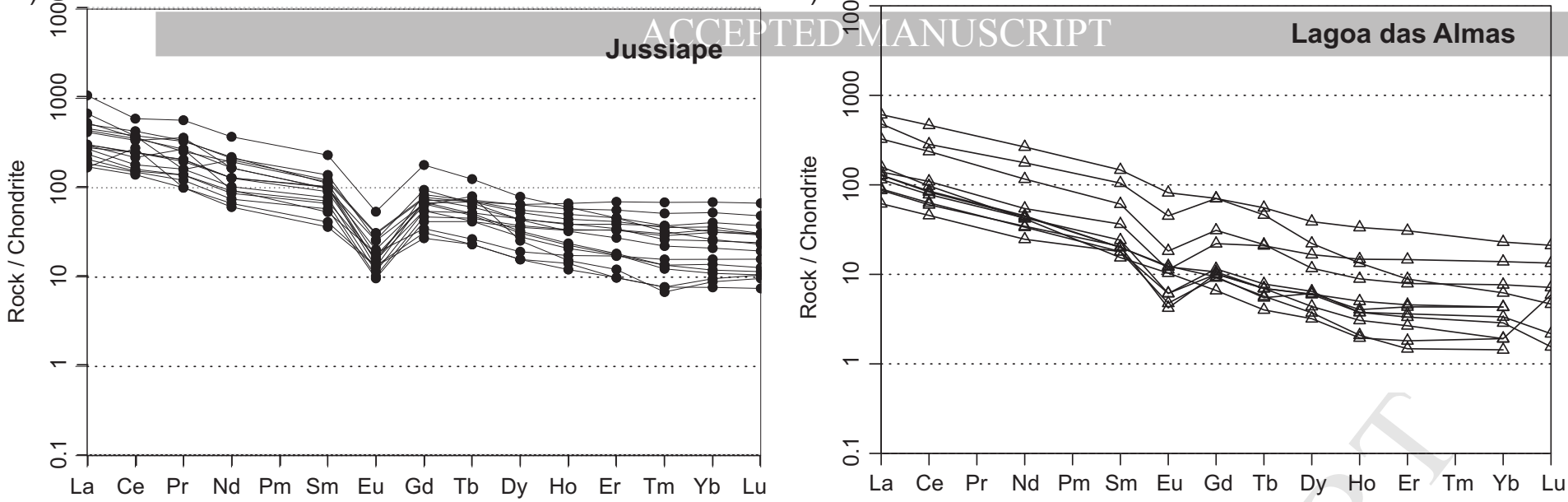

c)

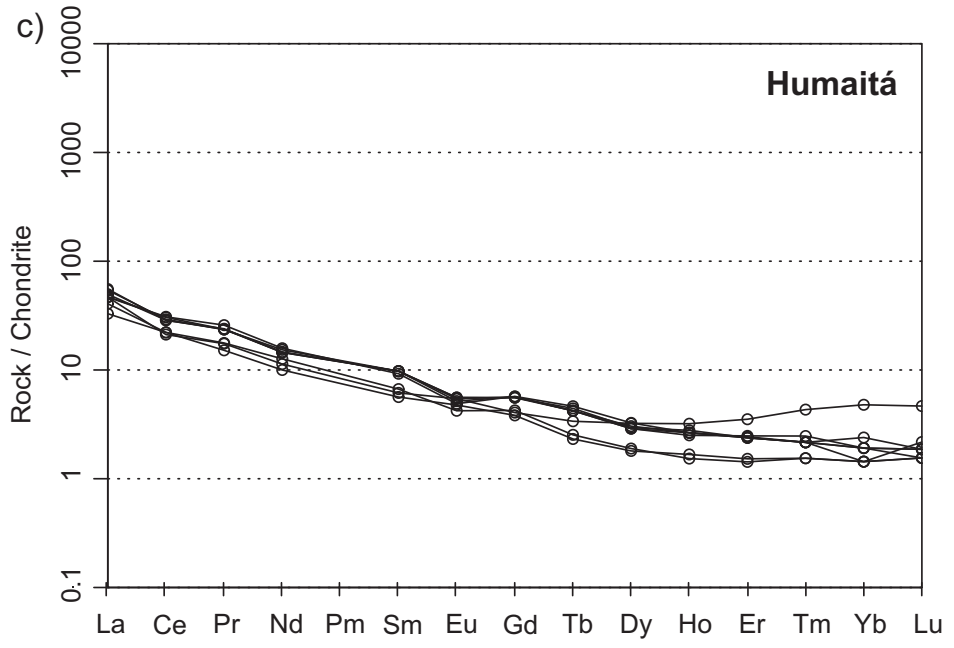

e)

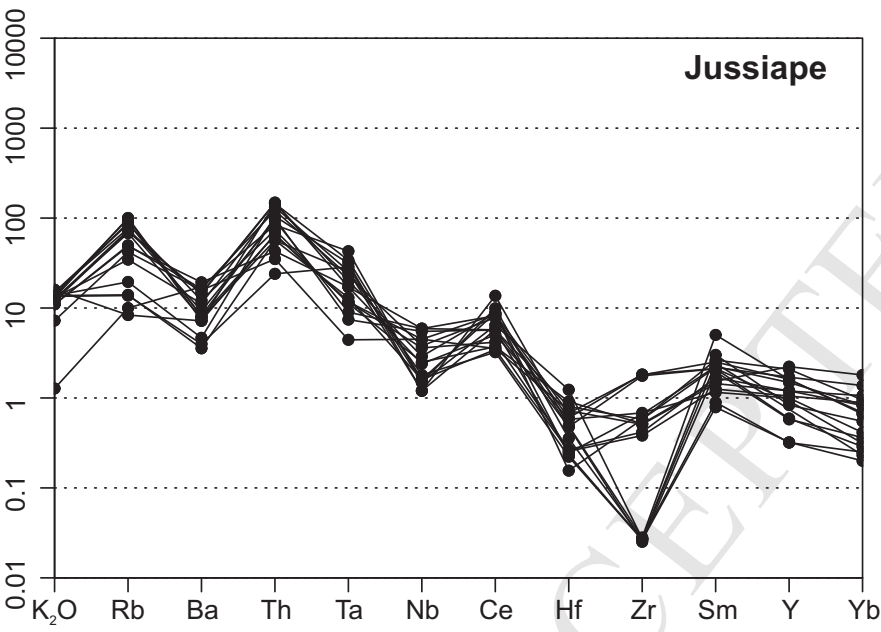

g)

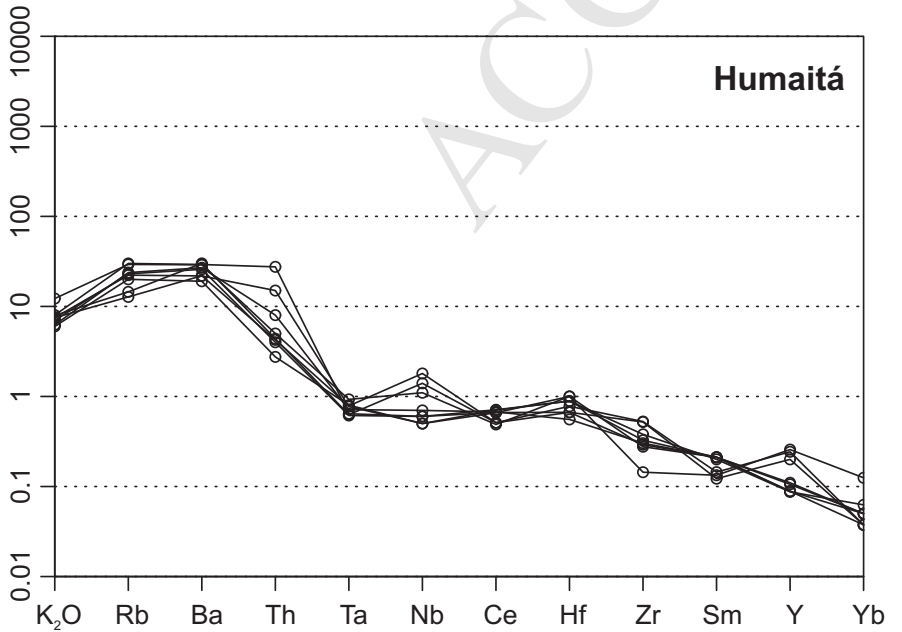

d)

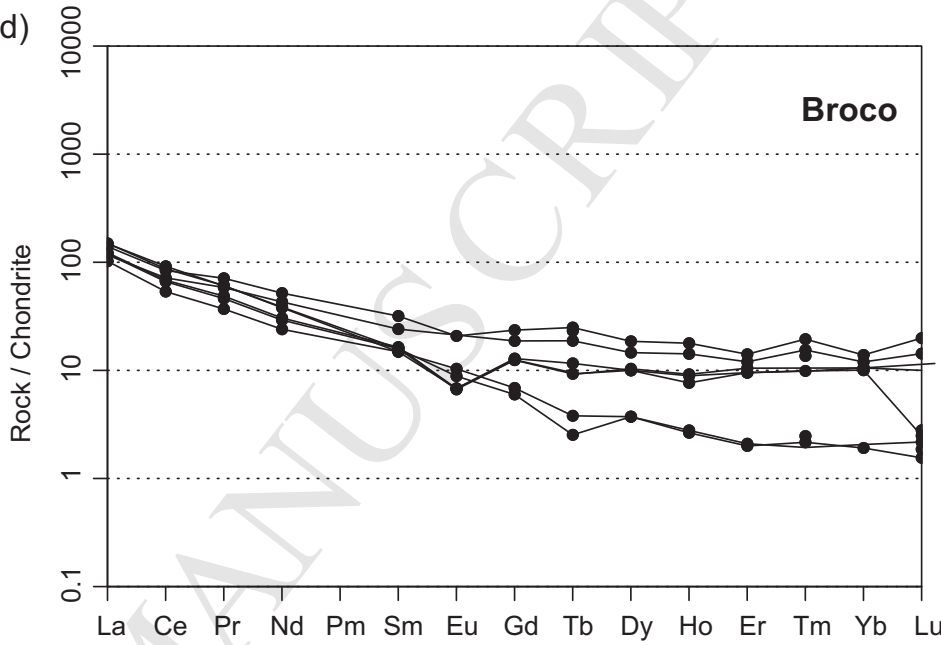

f)

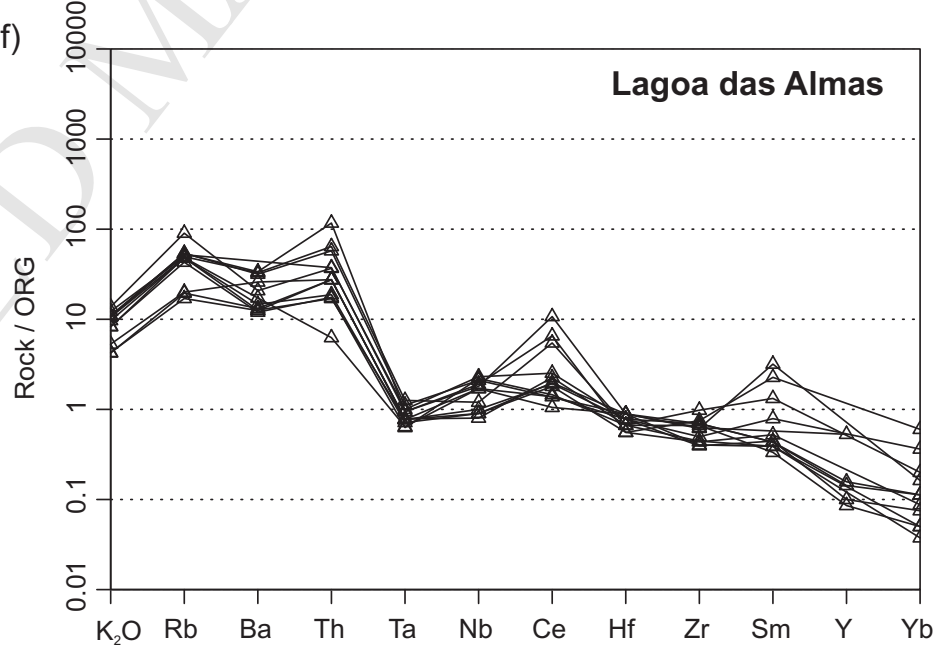

h)

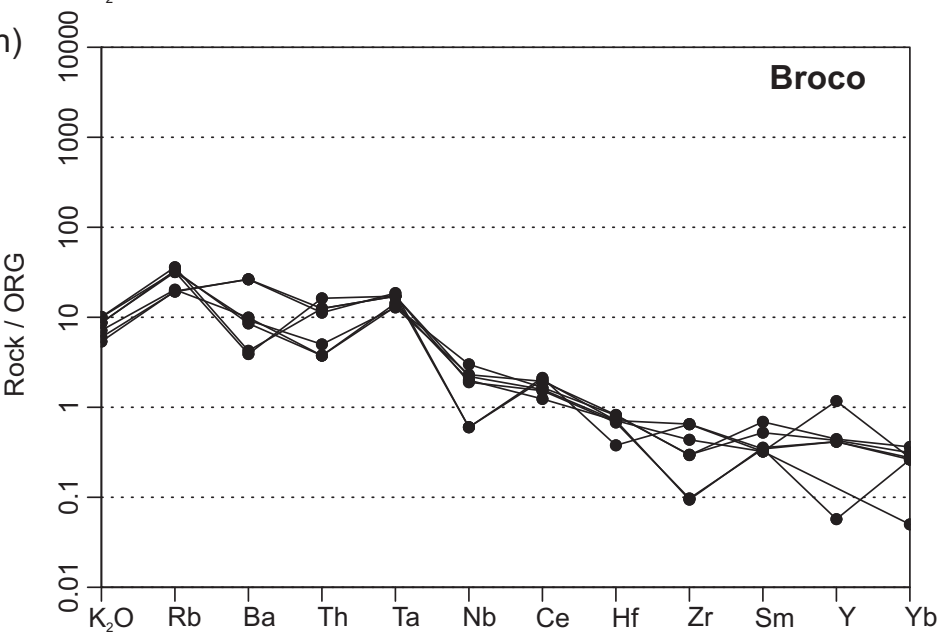




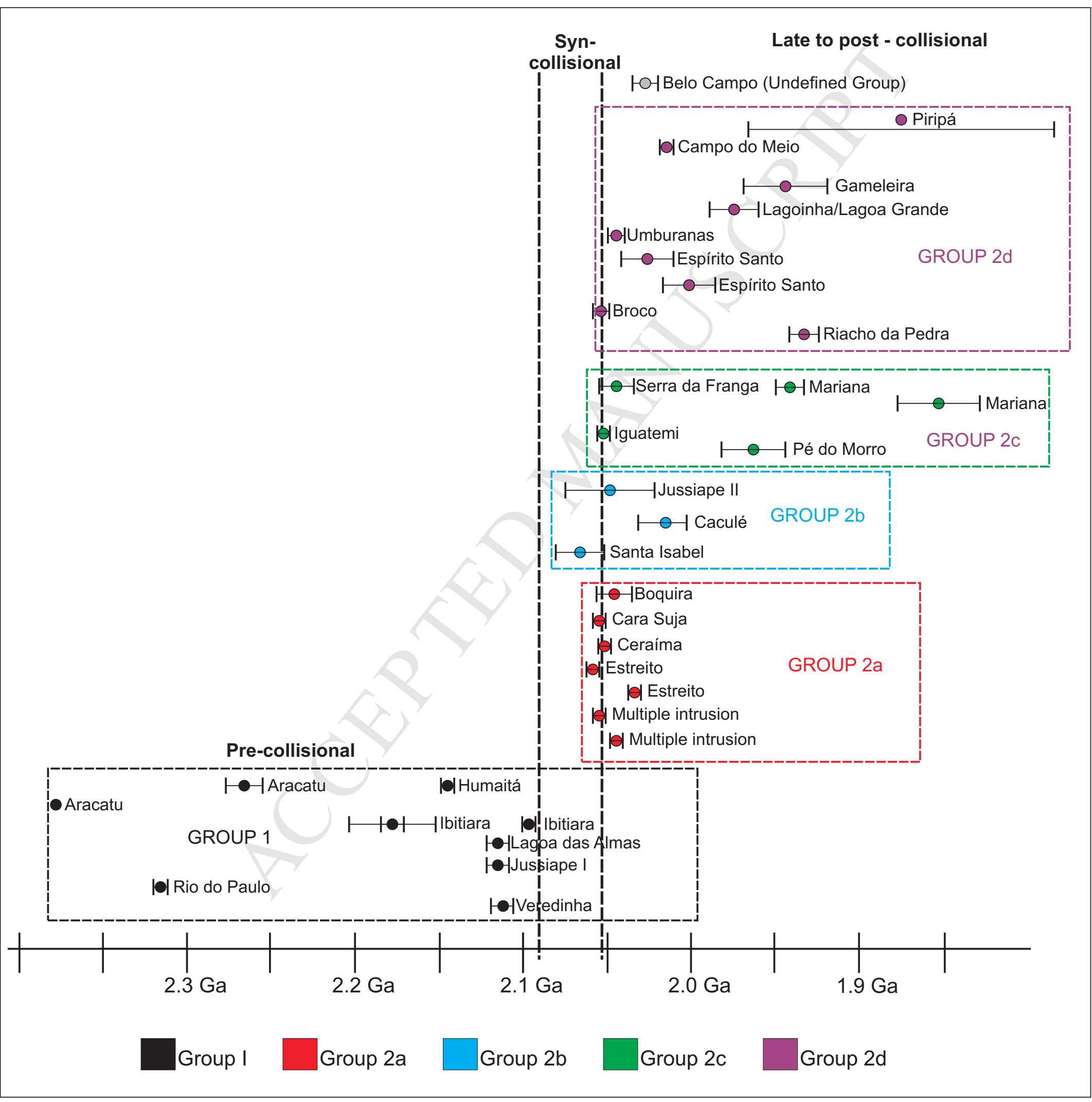




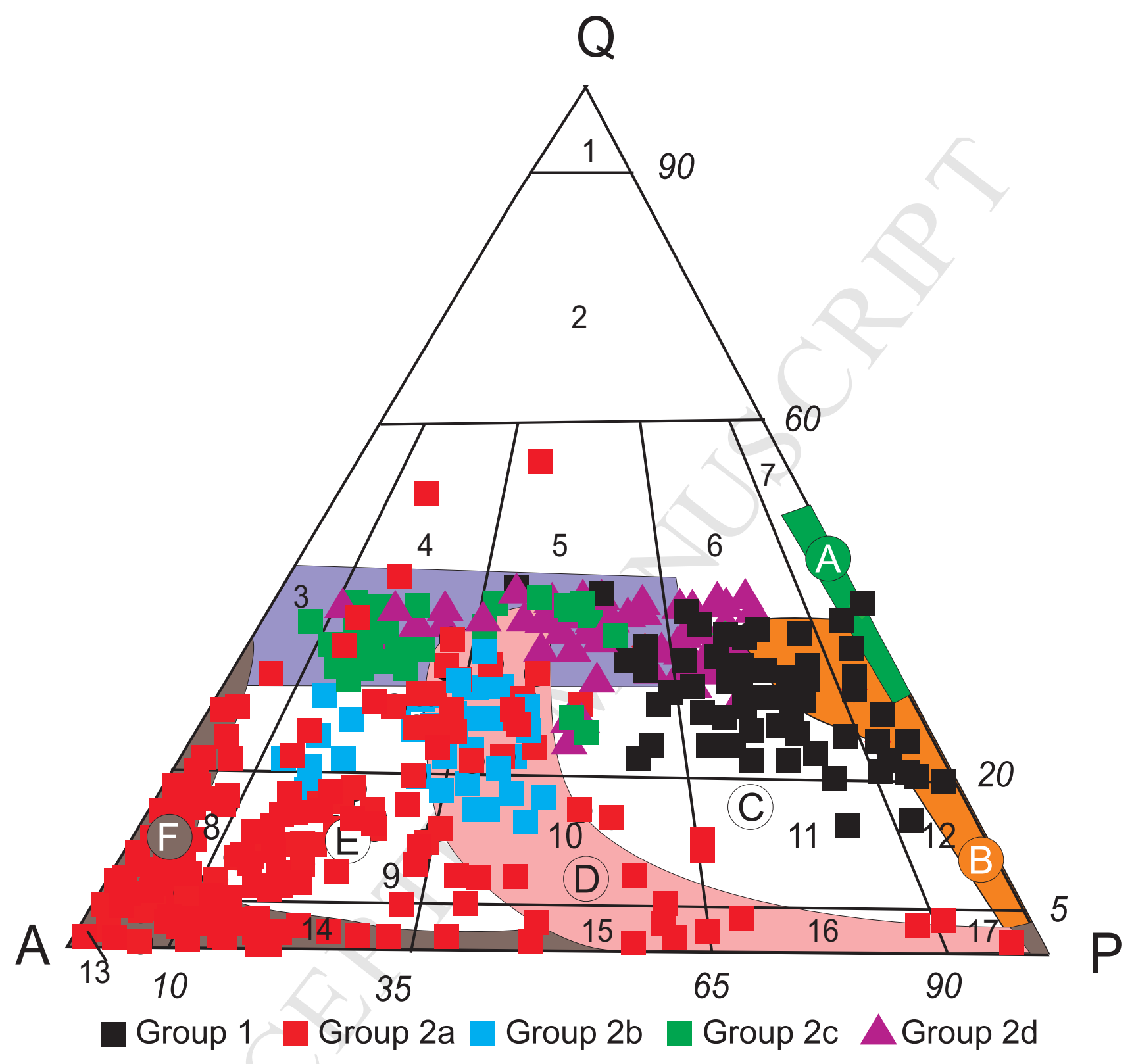

A tholeiitic trend (B) calc-alkaline-trondhjemitic (low K) trend

(C) calc-alkaline-granodioritic (medium K) trend (D) calc-alkaline monzonitic (high K) trend

(E) aluminous granitoids found in alkaline provinces $F$ alkaline and peralkaline trend

G overlapping field of granitoids formed by crustal fusion

1-Quartzolite, 2-Quartz-rich granitoids, 3-Alkali-granite, 4-Syenogranite, 5-Monzogranite, 6-Granodiorite, 7Tonalite, 8-Alkali-quartz sienite, 9-Quartz-syenite, 10-Quartz-monzonite, 11-Quartz-monzodiorite, 12-Quartzdiorite, 13-Alkali-syenite, 14-Syenite, 15-Monzonite, 16-Monzodiorite, 17-Diorite

\section{Figure 12}


a)

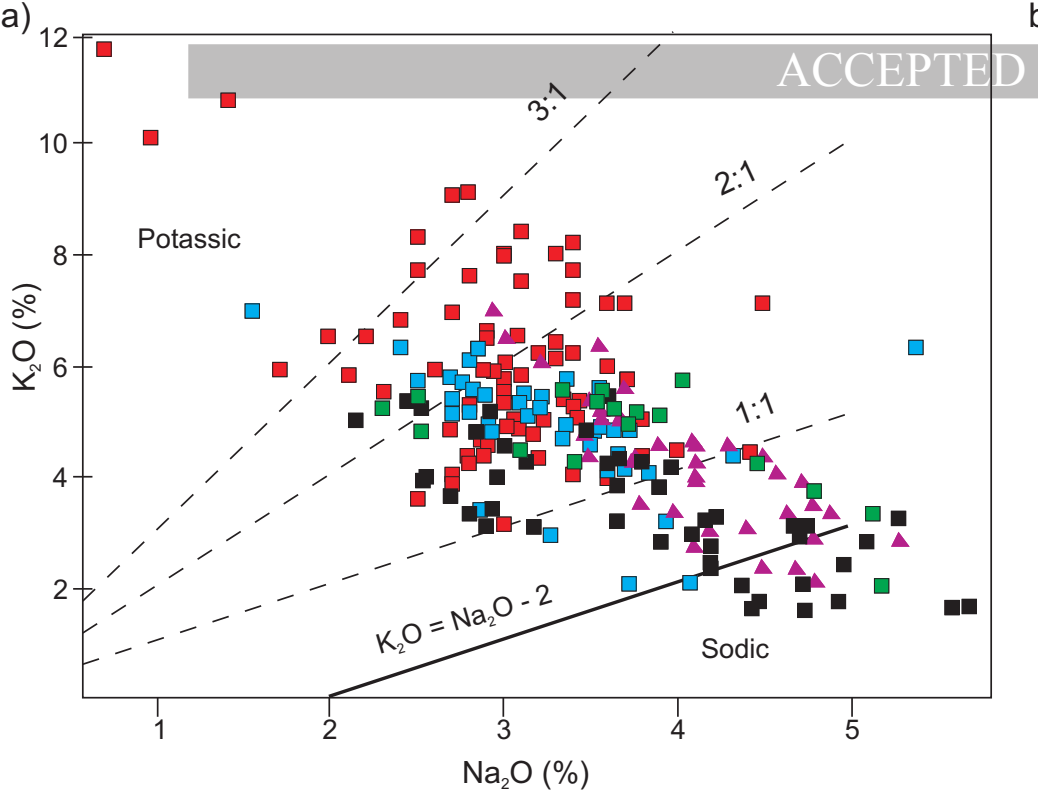

b)

c)

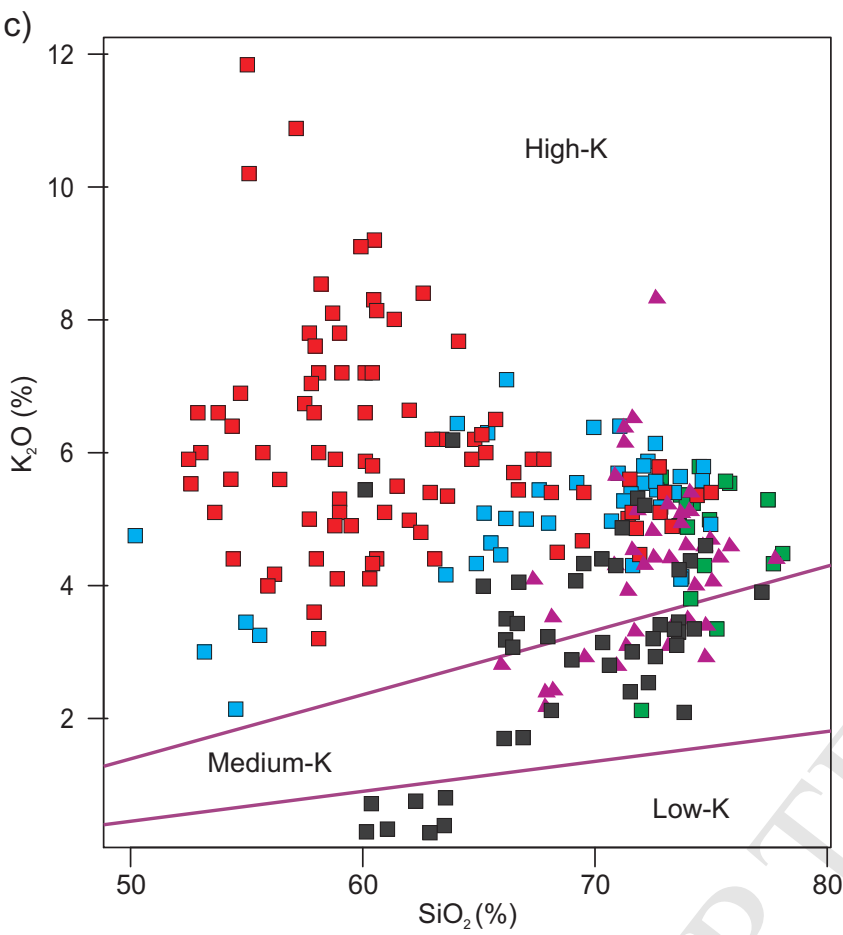

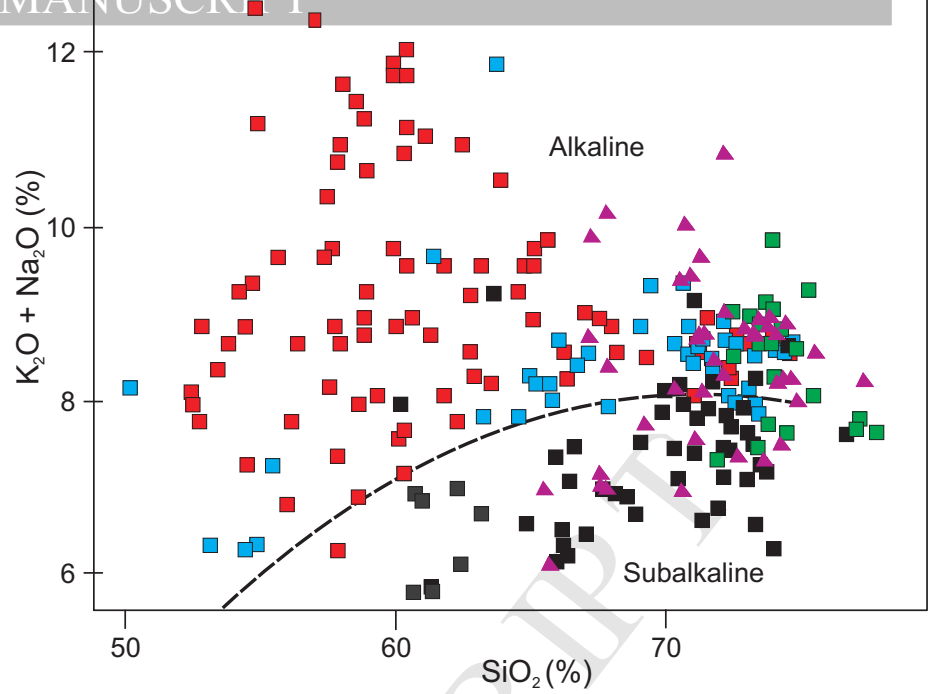

e)
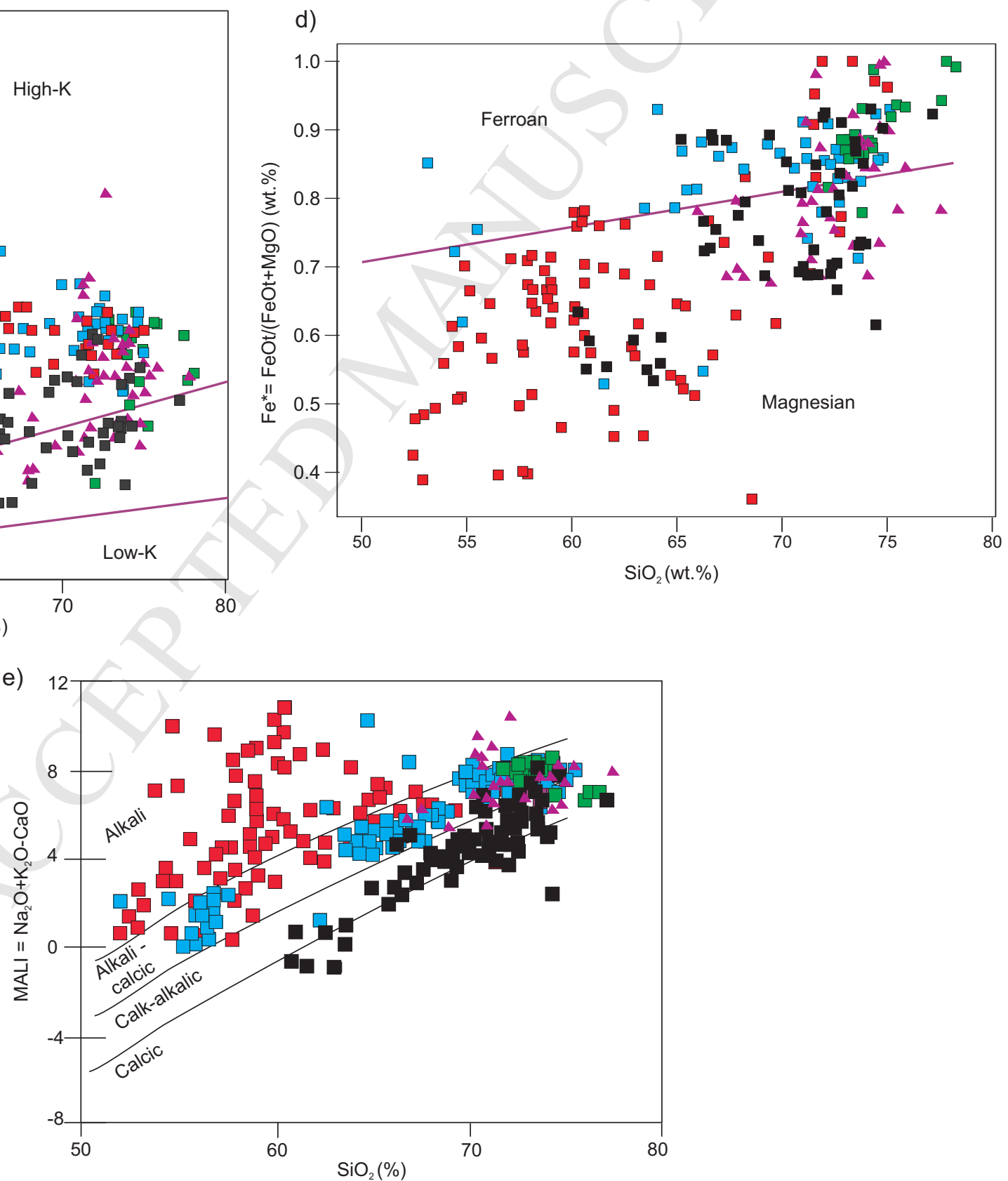
a)

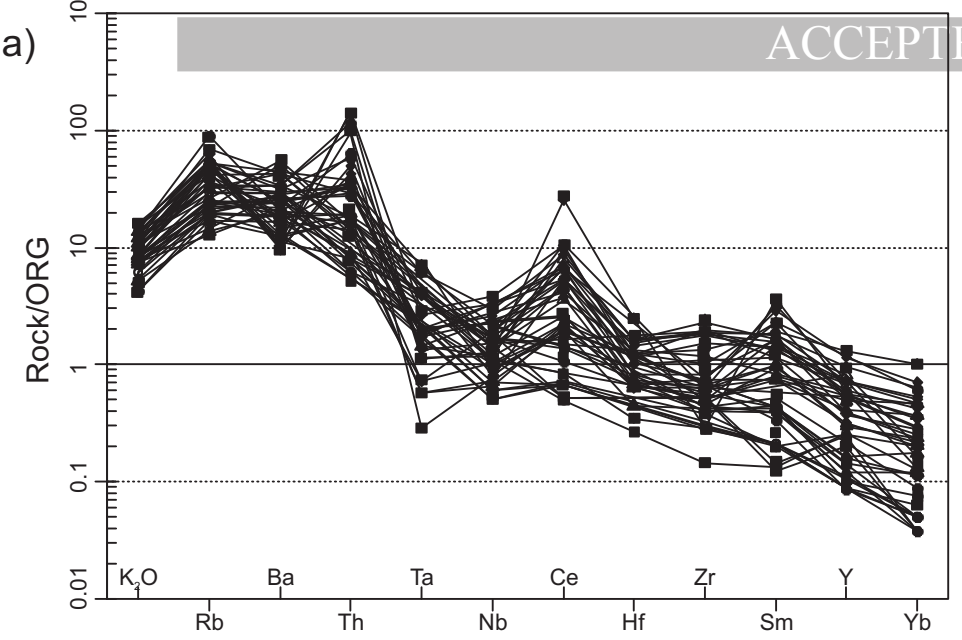

c)

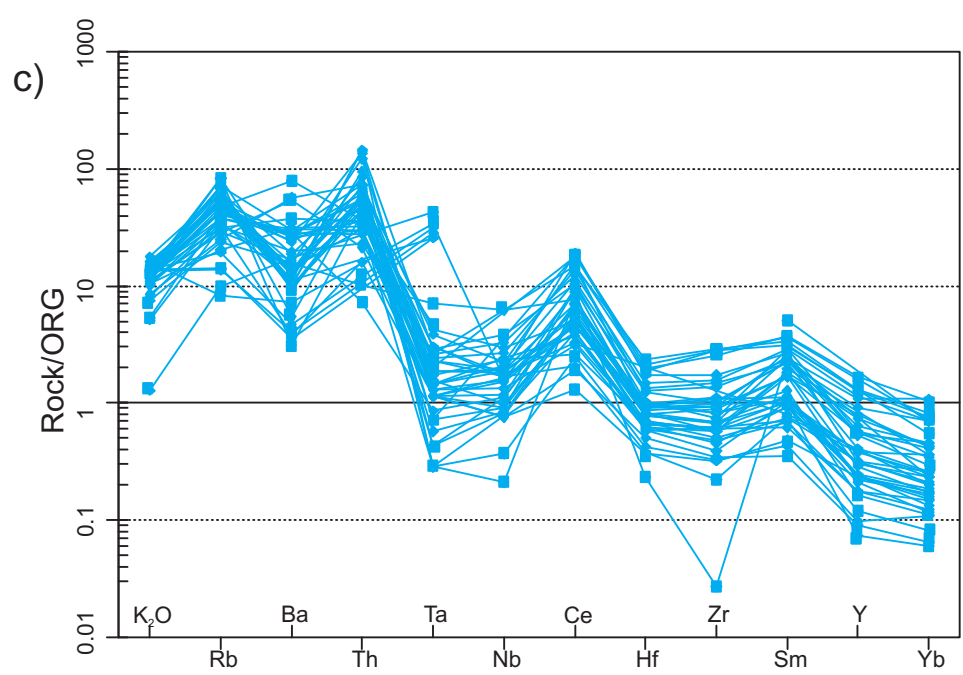

e)

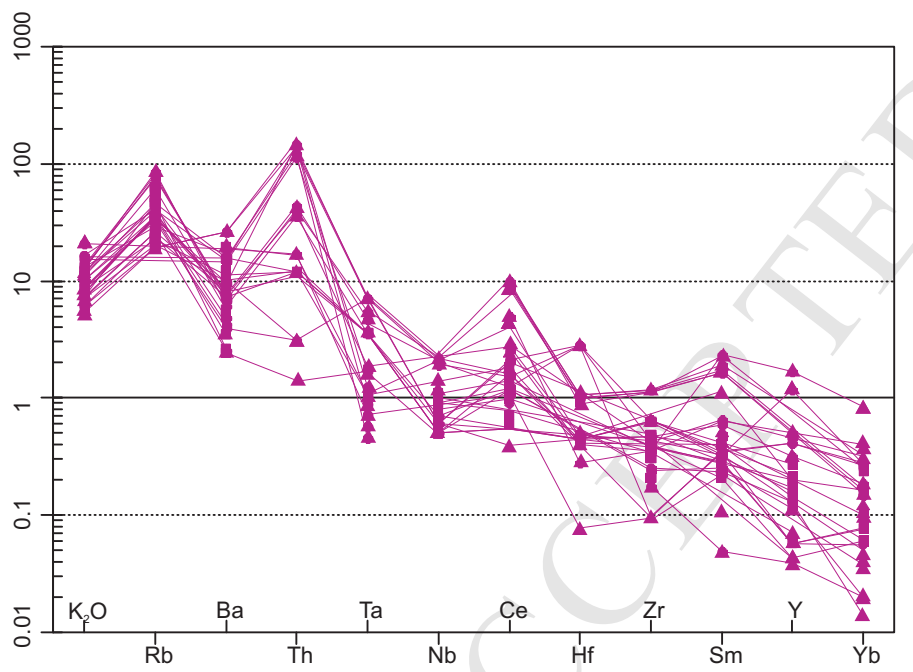

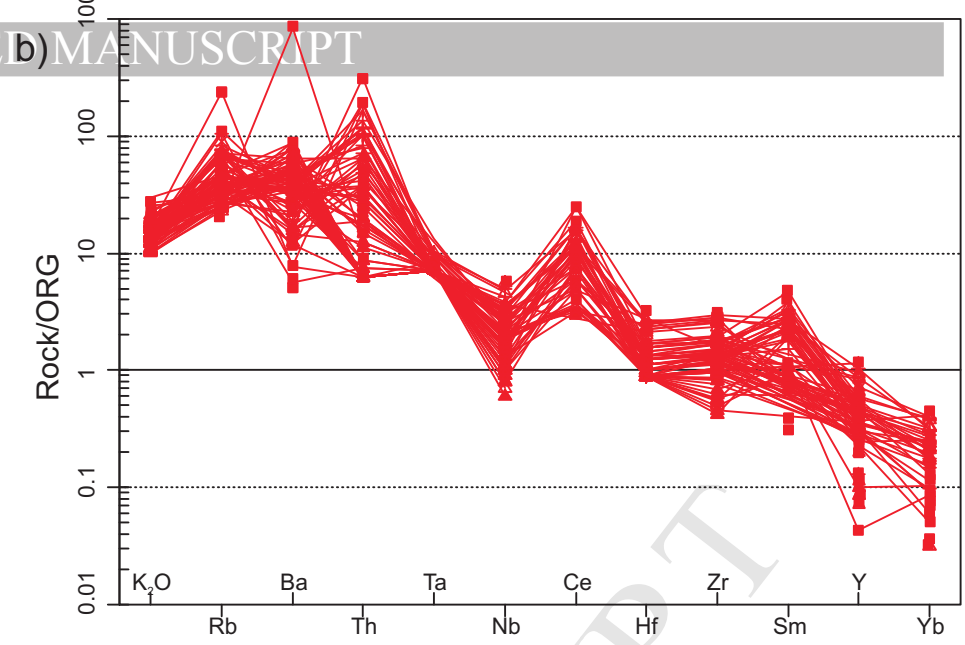
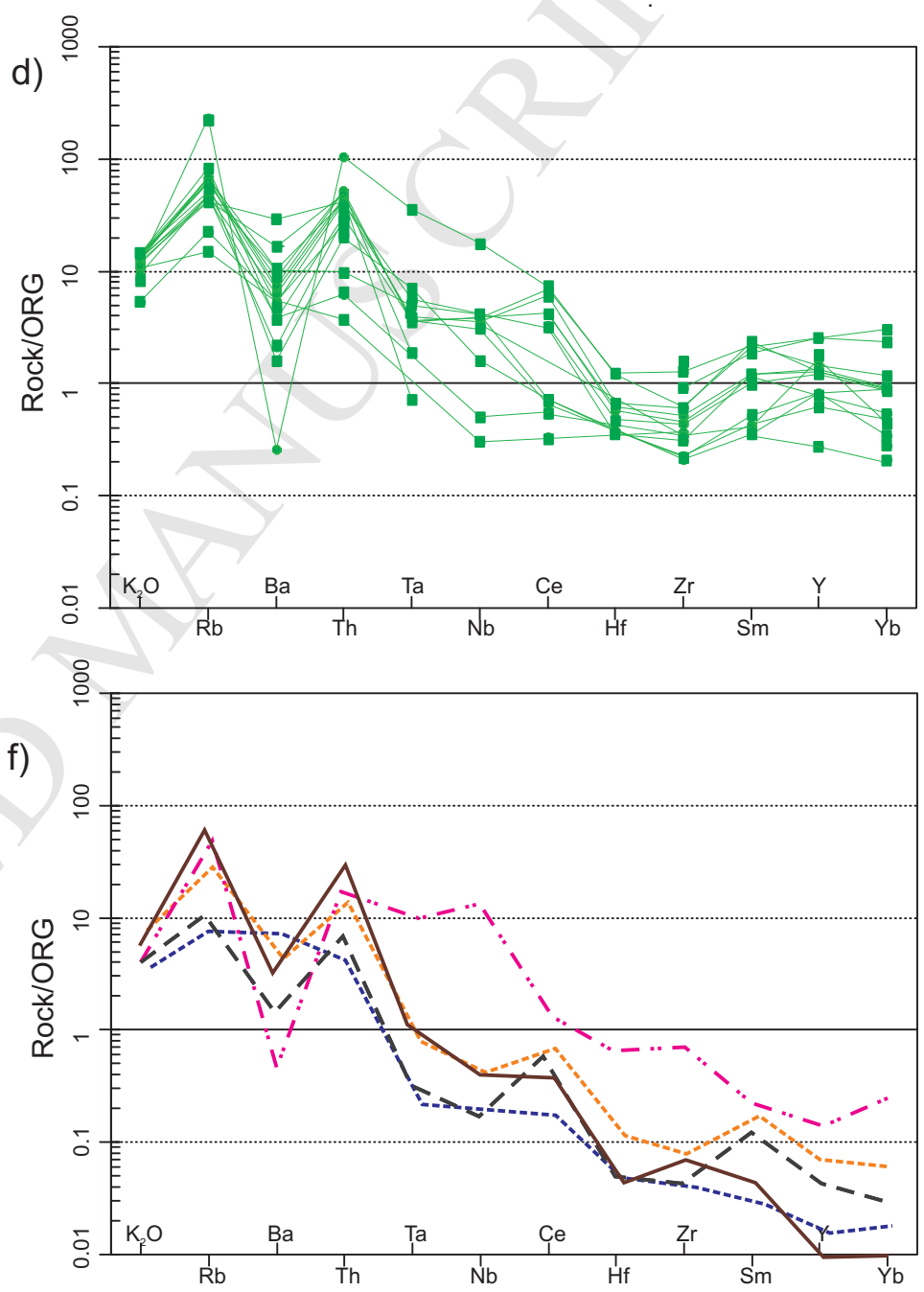

$\cdots$ Volcanic arc granites (Chile) $\cdots$ Volcanic arc granites (Jamaica)

Syn-collision granites (Tibet) $`$, Within plate granites (Ascencion)

- Post-collision granites

Group 1

Group 2a

Group 2b

Group 2c

$\Delta$ Group 2d

Figure 17 


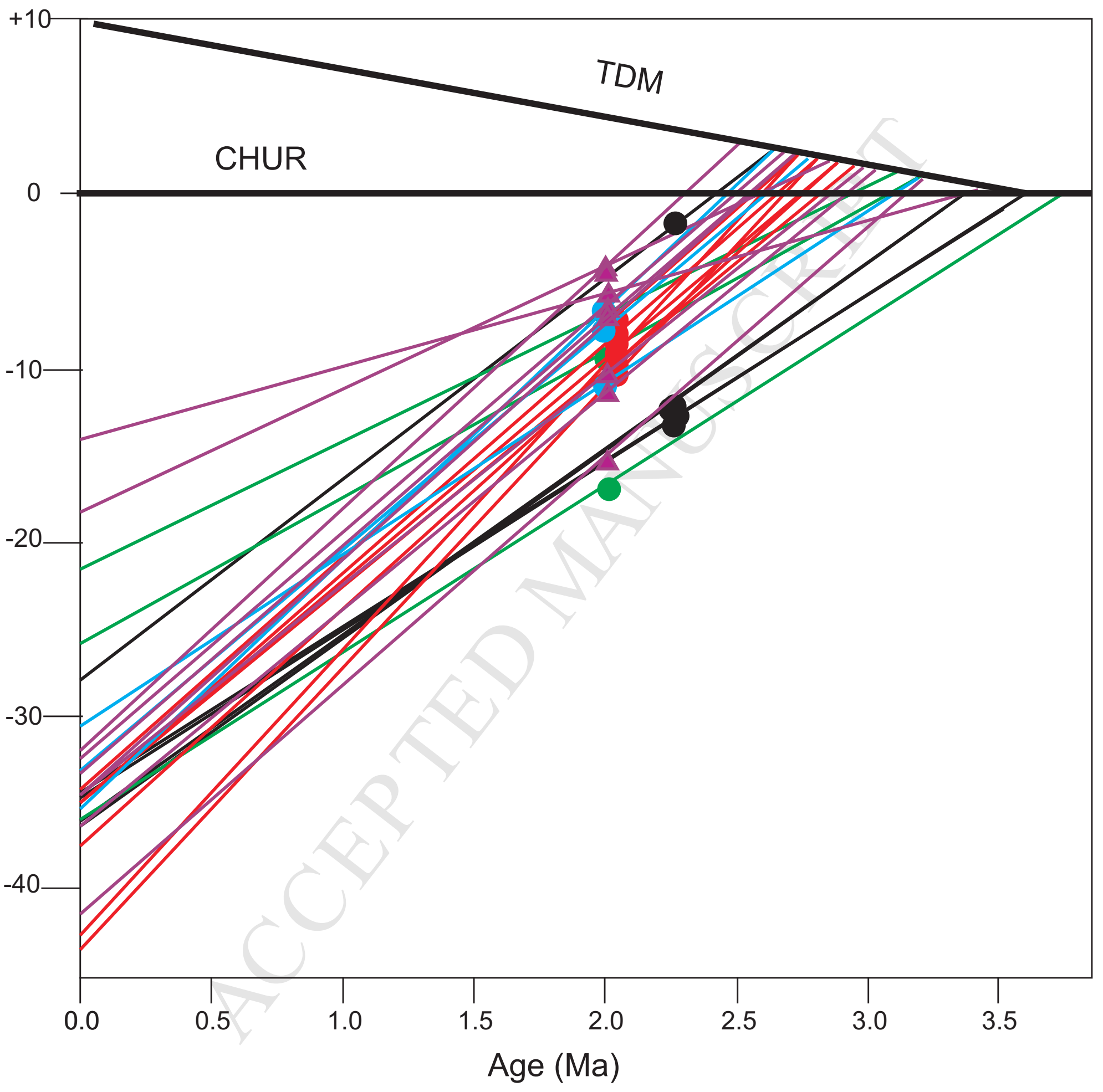

$\square$ Group $1 \square$ Group 2a $\square$ Group 2b $\square$ Group 2c $\Delta$ Group 2d 
a) $2400-2330$ (?) $\mathrm{Ma}$

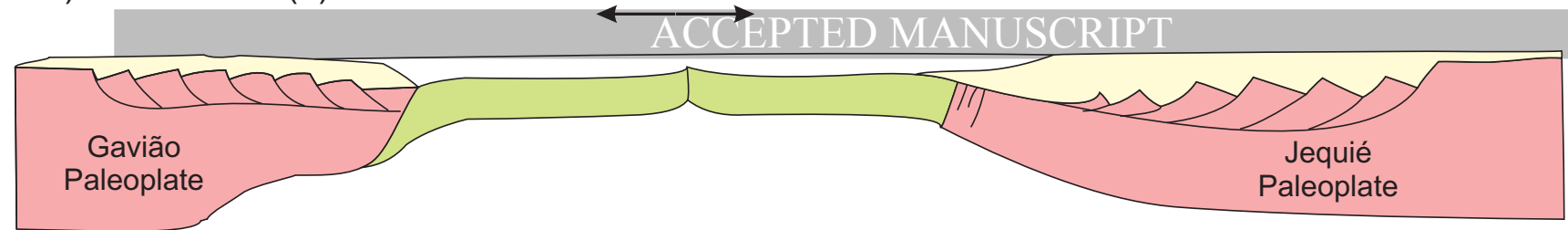

b) $2380-2120 \mathrm{Ma}$

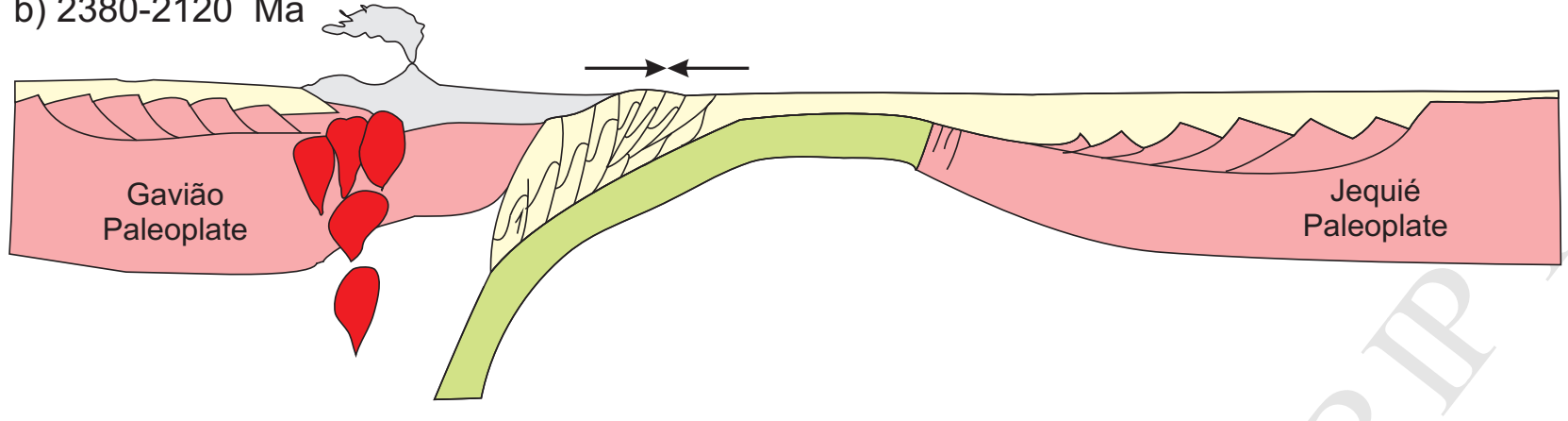

c) $2100-2090 \mathrm{Ma}$

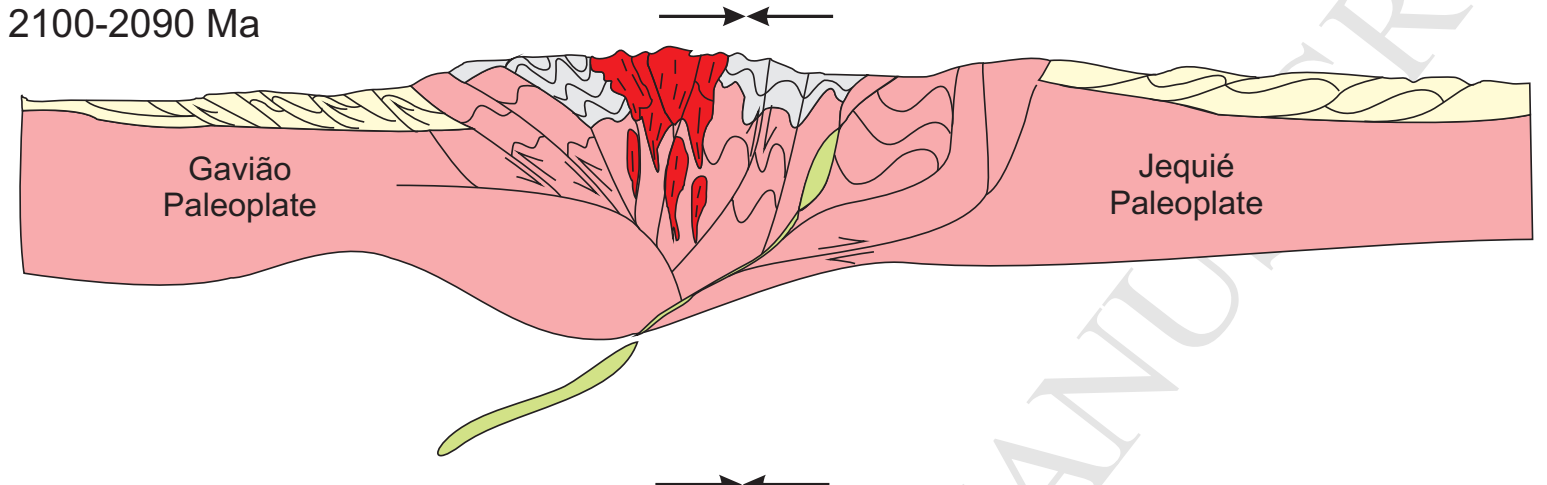

d) 2066-2030 Ma
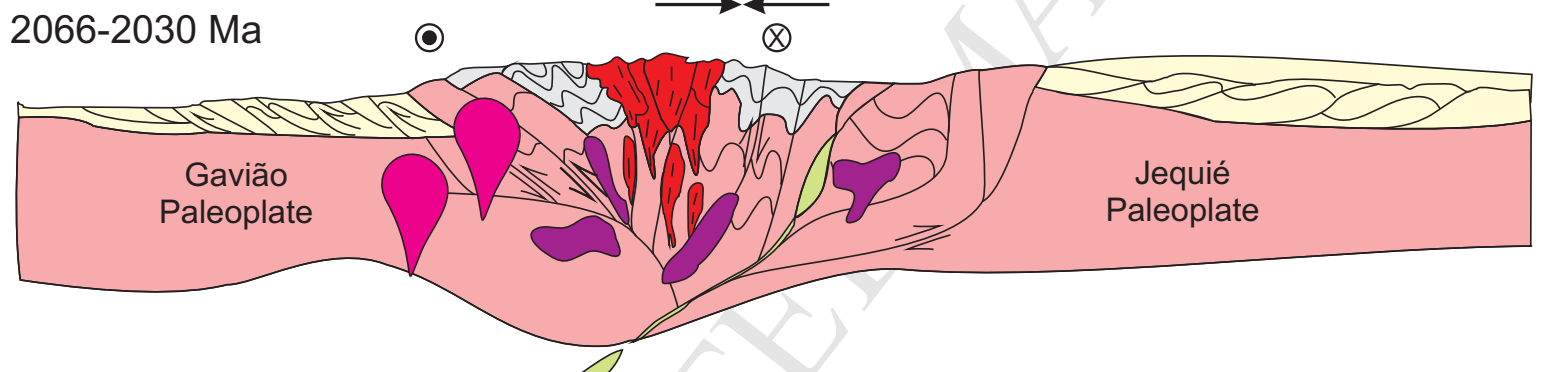

d) $2030-1900 \mathrm{Ma}$

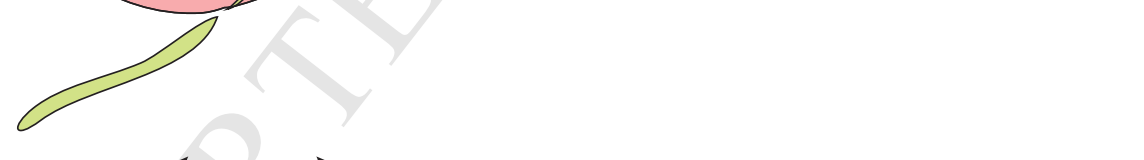

Gavião Paleoplate

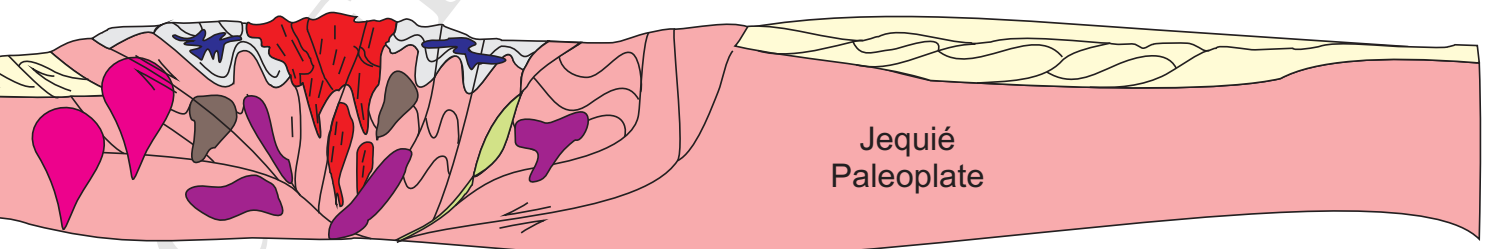

Legend

Calk-alkali, alkali-calcic to alkali granitoids (Grupo 2d)

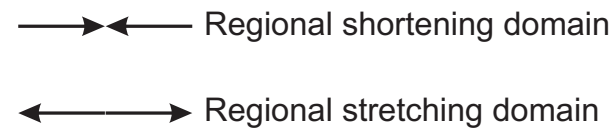

Alkali-calcic to alkali granitoids(Grupo 2c)

Alkali-calcic to alkali granitoids (Grupo $2 \mathrm{~b}$ )

Alkali to alkali - calcic granitoids (Group 2a)

$\otimes \odot$ sinistral movement

Calcic to calk-alkalic, pre-collisional granitoids (Group 1)

$\Sigma$ reverse movement

Metavolcanosedimentary rocks associated with Siderian-Riacian magmatic arc

Syn to pre-collisional metasedimentary rocks

Oceanic crust

Archean orthogneisses 


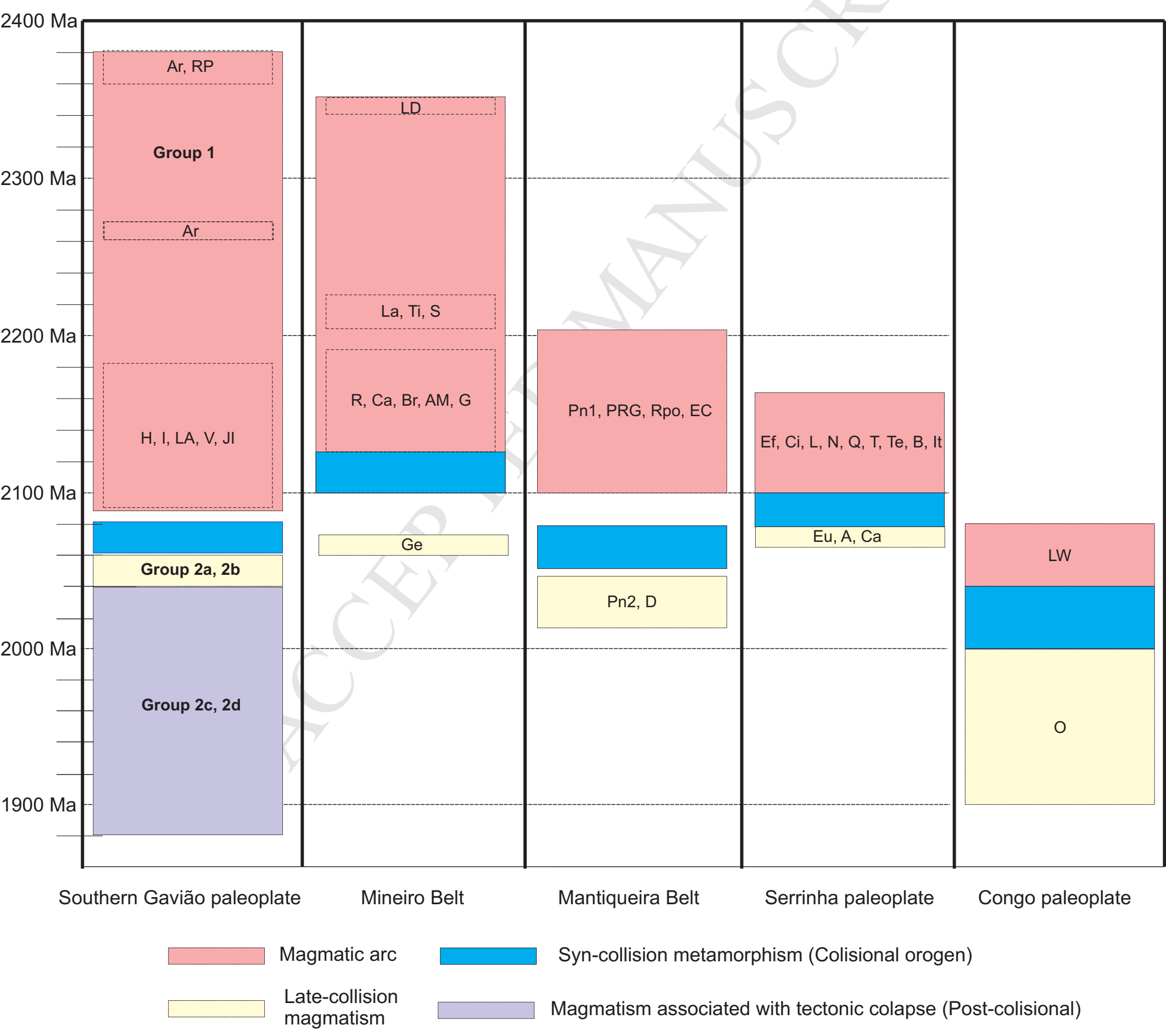

FIGURE 21 


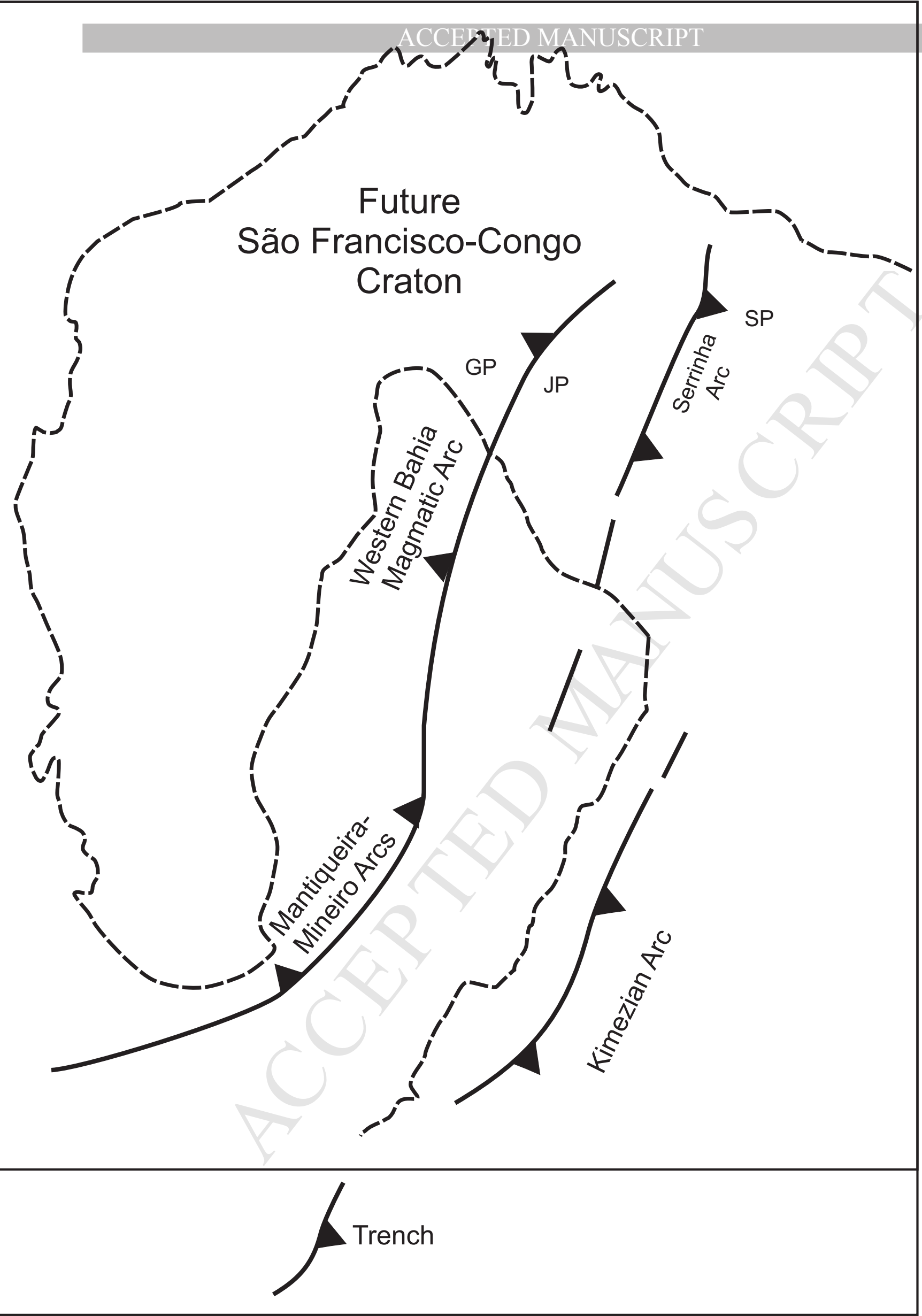

FIGURE 22 


\section{Group A}

- Aracatu

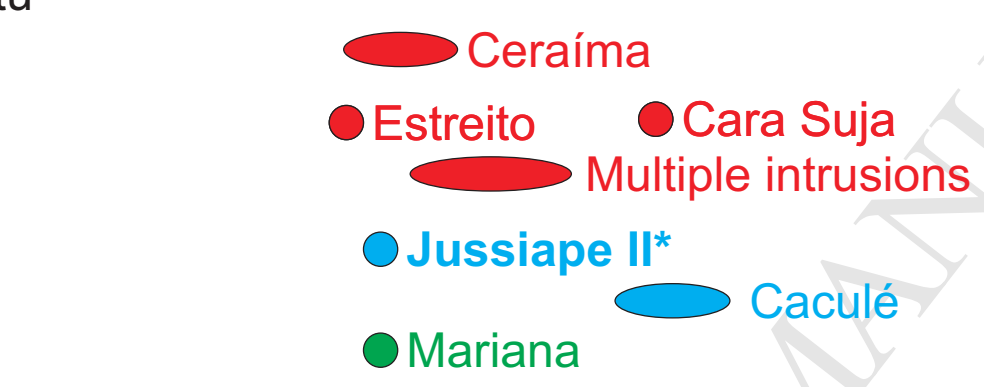

\section{Espírito Santo}

$\longrightarrow$ Umburanas

Belo Campo*

Igua

\section{emi}

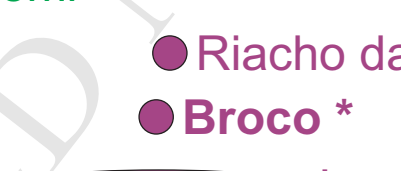

Lagó

\section{Caet}

Gameleira

\section{Granitoids of the Mineiro Belt}

Group B

Humaitá*

Pedras

Grande / Lagoinha

Alto Maranhão tonalite

Archean Basement of the São Francisco Craton Lavrals mafic dike swarm of Mineiro Belt

$-14$

$\begin{array}{ll}12 & -10\end{array}$

$-6$

$-4$

$\varepsilon_{\mathrm{Nd}}(2.2-2.0 \mathrm{Ga})$

* Granitoid studied

\section{- Group 1 Group 2a \\ Group $2 b$ \\ Group 2c ○ Group 2d}


Highlights

Twenty-nine Siderian-Rhyacian-Orosirian granitoids were recognized in the southern Gavião Paleoplate

In Gavião Paleoplate the age of Ryacian-Orosirian magmatism ranges between $1944 \pm 7$ and $2140 \pm 9 \mathrm{Ma}$.

Data suggest that some rocks were generated in subduction environment. 